\title{
THE PANAMA CANAL
}

AND ITS MAKERS

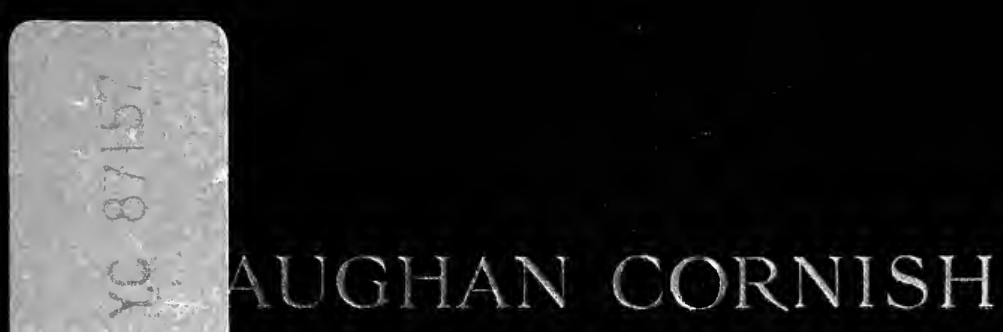




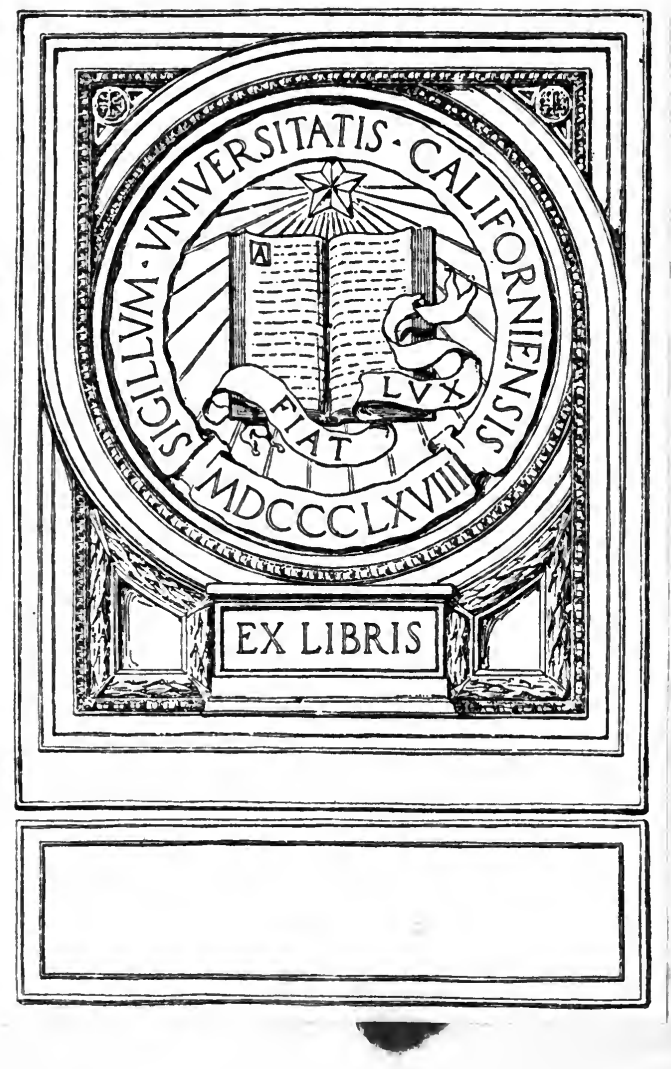


?

$\therefore$

$4=$

ins

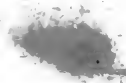

t.

is

an

i. 
Digitized by the Internet Archive in 2007 with funding from Microsoft Corporation 


\section{THE PANAMA CANAL AND I'TS MAKERS}




\section{THE RISE AND PROGRESS OF THE SOUTH AMERICAN REPUBLICS \\ By George W. Crichfield}

Illustrated. Two Vols. Royal 8vo, cloth, 25 s.

THE SOUTH AMERICAN SERIES

Edited by MARTIN HUME

Each Volume Demy 8vo, cloth, ros. 6d. net.

VOL. I.

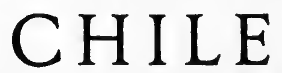

Its History and Development, Natural Features, Products, Commerce and Present Conditions. By G. F. ScotT Elliotr, M.A., F.R.G.S., Author of "A Naturalist in Mid Africa." With an Introduction by MARTIN HuME, a Map, and many Illustrations.

"An exhaustive and interesting account, not only of the turbulent history of this country but of her present conditions and seeming prospects."-Westminster Gazette.

"Will be found attractive and useful reading by the student of history, the geographer, the naturalist, and last, but assuredly not least, the British merchant."-Scotsman.

VOL. II.

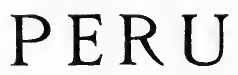

Its Former and Present Civilisation, Topography and Natural Resources, History and Political Conditions, Commerce and General Development. By C. Reginald ENock, F.R.G.S., Author of "The Andes and the Amazon." With an Introduction by MARTIN HUME, a Map, and numerous Illustrations.

"An important work. . . The writer possesses a quick eye and a keen intelligence; is many-sided in his interests, and on certain subjects speaks as an expert. The volume deals fully with the development of the country, and is written in the same facile and graphic style as before. Illustrated by a large number of excellent photographs."-The Times.

"A magnificent collection of information on this interesting country. The author's vivid and eloquent description invests it for us with some of the glamour it possessed for the Conquistadores of the sixteenth century; and on closing the book the reader feels tempted to set out at once for Peru."-Yorkshire Observer.

IN PREPARATION

VOL. III.

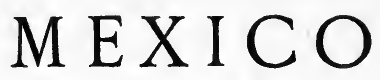

By C. REgINALd ENOCK

LONDON : T. FISHER UNWIN 
!

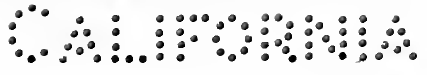




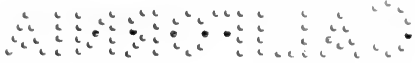

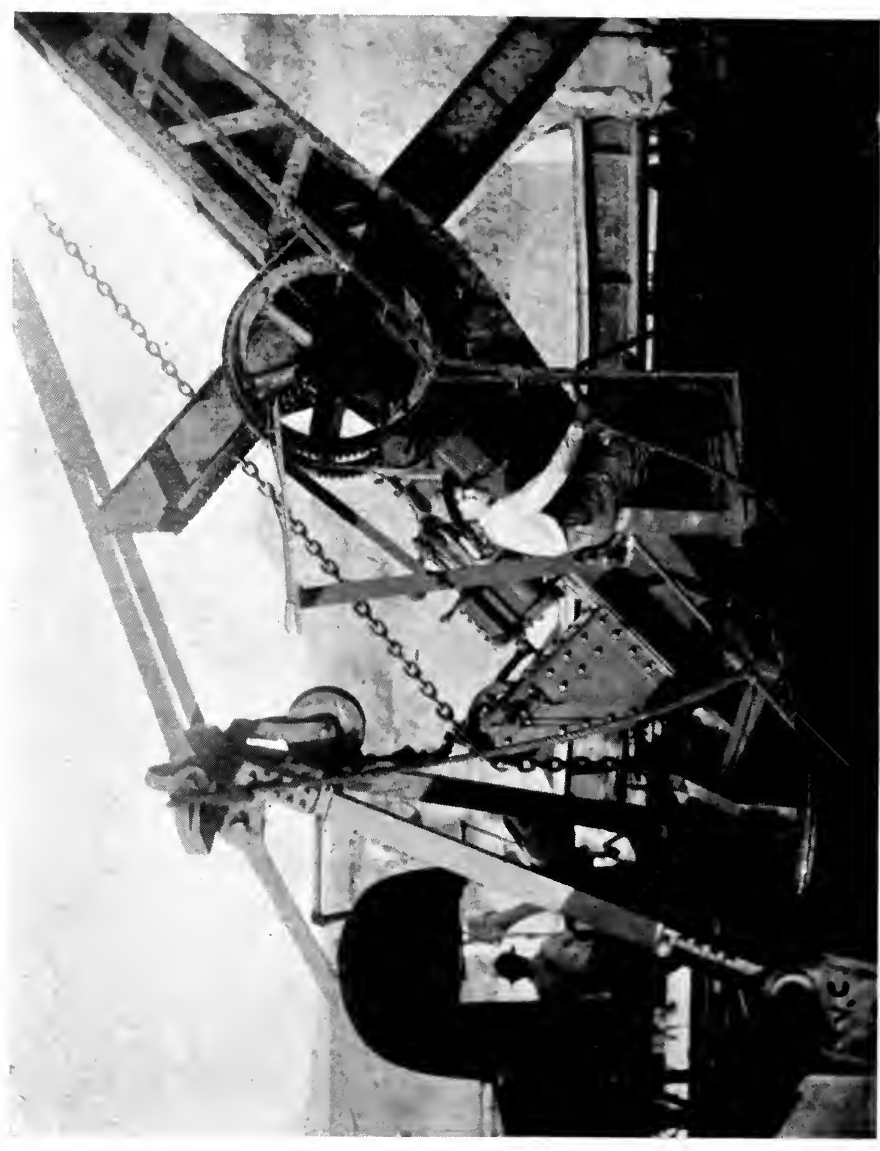

渵

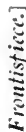




\section{THE PANAMA CANAL \\ AND ITS MAKERS . .}

\section{By VAUGHAN CORNISH}

Doctor of Science (Manchester Univ.), Fellow of the Royal Geographical, Geological, and Chemical Societies of London, Member of the Fapan Society

WITH MAP, PLANS, AND PHOTOGRAPHS TAKEN BY THE AUTHOR

T. F I S H E R U N W I N LONDON : ADELPHI TERRACE LEIPSIC : INSELSTRASSE 20 
061993

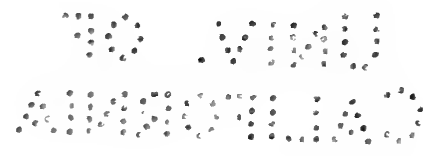

(All rights reserved.) 


\section{THIS BOOK IS DEDICATED}

To

THE REVEREND CHARLES JOHN CORNISH, M.A. (OxON), OF FLeET, HANTS, AND SALCOMBE REGIS, DEVON, BY

HIS AFFECTIONATE SON, THE AUTHOR. 



\section{PREFACE}

T AM indebted to many persons for advice 1 and information in connection with my study of the Panama Canal, and wish to thank particularly His Excellency the Rt. Hon. James Bryce, the Rt. Hon. Lord Avebury, Mr. Claude Mallet, C.M.G., Colonel George E. Church, Colonel George W. Goethals, chairman of the Isthmian Canal Commission, and his colleagues, Colonel W. C. Gorgas, M.D., Major D. D. Gaillard, Major William L. Sibert, Mr. Jackson Smith, and Mr. Bucklin Bishop. Also Major Chester Harding, Mr. Arango, Mr. G. R. Shanton, Chief of Police, Mr. William Gerig (formerly in charge of the Gatun Dam), Mr. Mason W. Mitchell, and Mr. Tracy Robinson.

VAUGHAN CORNISH.

November, 1908. 



\section{CON'TEN'TS}

PAGE

INTRODUCTION

15

CHAPTER I

HISTORICAL REVIEW . $\quad$ - $\quad$ - $\quad$ - 23

CHAPTER . II

ON THE CANAL AS IT IS TO BE

. 45

CHAPTER III

ON THE PRESENT CONDITION OF THE CULEBRA CUT, AND ON THE METHODS EMPLOYED FOR EXCAVATION AND DISPOSAL OF THE SPOIL

- 79

\section{CHAPTER IV}

THE MEN ON THE ISTHMUS .

. 99 


\author{
CHAPTER V \\ PAGE \\ HEALTH ON THE ISTHMUS AND THE FUTURE OF THE \\ WHITE RACE IN THE TROPICS . . . 119
}

\begin{abstract}
CHAPTER VI
ON THE SHORTENING OF DISTANCES BY SEA, AND ON THE STEAMSHIPS AVAILABLE FOR CANAL TRANSIT 151
\end{abstract}

CHAPTER VII

THE COST OF THE CANAL

.171

INDEX . 


\section{ILLUSTRATIONS}

MAKERS OF THE CANAL

STATUE OF COLUMBUS, CHRISTOBAL, COLON
CHRISTCHURCH, COLON
LOCK AND DAM SITE, GATUN .
(The house is on the crest-line of the dam, which will extend
to the hills on the right)

EXCAVATING FOR THE DOUBLE FLIGHT OF THREE LOCKS AT

GATUN

(In fine-grained argillaceous sandstone rock)

RE-LOCATION OF RAILWAY ABOVE GATUN DAM .

(The trestle embankment will run as a causeway across a bay of the lake)

MOTOR TROLLEY FOR INSPECTION OF WORKS

(In the background are screened houses of employees)

TROPICAL FOREST, WITH HEAVY GROWTH OF PARASITIC PLANTS .

JUNGLE WITH PIPE THROUGH WHICH OIL IS CONVEYED BY

GRAVITATION ACROSS THE ISTHMUS $\quad$ • $\quad$ • 36

CHAGRES RIVER NEAR BARBACOES . . . . 42

(In the dry season-looking down stream)

CHAGRES RIVER NEAR OBISPO

(In the dry season)

FRENCH DREDGER IAID UP

(Several of these have recently been put in use again) 
TO FACE PAGE

FRENCH TRUCKS PARTLY COVERED WITH FOREST GROWTH - 48

(Many of these were used at first by the Americans, but are now replaced by larger ones)

EXOAVATION NEAR TAVERNILLA • . . . $\quad 52$

RIVER CHAGRES AND RAILWAY NEAR GORGONA • . $\quad 52$

LIDGERWOOD UNLOADER, WINDING APPARATUS . . . 56

ANOPHELES BRIGADE OILING A DITCH . . . $\quad$ • 56

100-TON WRECKING CRANE, GORGONA . . . . 62

INTERIOR OF MACHINE SHOP, GORGONA $\quad . \quad$. 62

MACHINE SHOPS, GORGONA $\quad$ - . $\quad . \quad$. 66

CLUB HOUSE FOR EMPLOYEES, GORGONA • • 66

(Managed by the Y.M.C.A.)

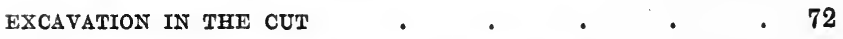

PIPE FOR DIVERSION OF A RIVER, NEAR EMPIRE • • 72

IN THE CUT, WIDTH 500 FEET . $\quad . \quad \ldots \quad$. $\quad . \quad 76$

IN THE CUT, LOOKING SOUTH TOWARDS CULEBRA • $\quad 76$

(The gorge between Golden and Silver Hills just visible)

ROCK DRILL

(These machines bore a hole 30 feet deep in eight hours)

ROCK DRILLS AT WORK IN THE CUT . $\quad . \quad \ldots \quad . \quad 32$

THE CUT, LOOKING NORTH FROM CULEBRA . . . 86

THE CUT, LOOKING SOUTH FROM CULEBRA . . . 86

FRON CULEBRA, LOOKING EAST TO DISTANT HILLS • • 92

FROM CULEBRA, LOOKING EAST ACROSS THE CUT · . 92

(Terraces formed by landslip are just visible behind the smoke of a distant steam shovel)

FROM CULEBRA, LOOKING EAST TO GOLDEN HILL • • 96

(Showing excavation in steps and ledges. Each ledge has carried a railway track) 
THE CUT AT CULEBRA, LOOKING NORTH

96

(The scarped face of Golden Hill on the right. Taken April, 1908, in the then bottom of the cut, 120 feet above Canal bottom)

GANG OF WEST INDIAN LABOURERS

(Unloading spoil-train at Gatun)

GANG OF SPANISH LABOURERS AT CULEBRA

(Working in the sun in April, which is one of the hottest months, less than 10 degrees from the equator. The men are wearing European kit)

STEAM SHOVEL EXCAVATING SOIL AT CULEBRA . . 106

STEAM SHOVEL UNLOADING INTO A DIRT CAR . . 106

STEAM SHOVEL NEAR END OF STROKE • . . . 112

(The marks of the teeth made in a former stroke are visible on the right. Golden Hill, with the highest berm, or ledge, in the distance)

STEAM SHOVEL, STROKE FINISHED, LOADED WITH SOIL

SHOVEL-MEN AT CULEBRA

SCREENED BUNGALOW, CHRISTOBAL, COLON . . . 122

SCREENED QUARTERS OF EMPLOYEES, CULEBRA • 122

READING ROON, EMPLOYEES' CLUB, CULEBRA • . 126

HALI OF ENPLOYEES' CLUB, CULEBRA . 126

CUT SOUTH OF CULEBRA, LANDSLIP ON LEFT • • • 132

LOOKING NORTH, THE SCARPED FACE OF GOLDEN HILL ON

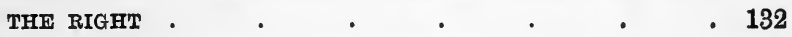

LOOKING NORTH FROM RAILWAY BRIDGE AT PARAISO • 136

ABANDONED FRENCH MACHINERY $\quad$. $\quad . \quad . \quad 136$

GANG OF EUROPEAN LABOURERS (IN 1907) . . . 142

A FORMER HOT-BED OF MALARIA, NOW DRAINED . 142 
NEAR THE SITE OF MILAFLORES LOCKS . $\quad . \quad$. 146

LOOKING NORTH TO CULEBRA DIVIDE FROM ANCON HILL 146

RIO GRANDE, NEAR LA BOCA $\quad . \quad \ldots \quad$. $\quad . \quad 154$

RIO GRANDE, FROM ANCON HILT $\quad$. $\quad . \quad$. $\quad 154$

(Country north of that shown in the last photograph)

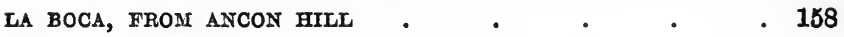

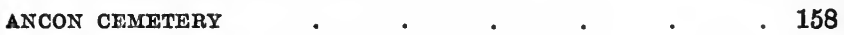

COMMISSION'S HOTEL AT ANCON . $\quad$. $\quad$. $\quad$. $\quad 162$

ADMINISTRATION BUILDING, ANCON $\quad . \quad \ldots \quad . \quad 162$

VIEW FROM SPANISH FORT, PANAMA $\quad . \quad$. $\quad . \quad 166$

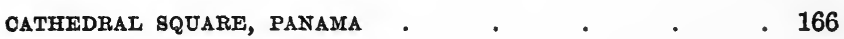

PALACE OF PRESIDENT OF THE REPUbLIC OF PANAMA • $\quad 174$

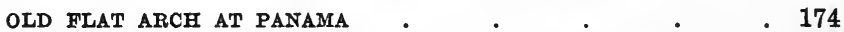

(Adduced as evidence of comparative freedom of Panama from destructive earthquakes)

MAP OF CANAL ZONE . . . At end of volume

(Showing also profile of Canal, cross section of Culebra Cut, the borings below Gatun dam, and the cross section of Gatun dam as designed in April, 1908. The design of this dam, however, is still undergoing modifications) 
INTRODUCTION 


\section{INTRODUCTION}

$A \mathrm{~T}$ the present moment the Canal Zone A of the Isthmus of Panama is the most interesting place in the world. Here is gathered an army of 40,000 men engaged in the epoch-making work of uniting the Atlantic and Pacific Oceans, and here is the greatest collection of machinery ever massed for the accomplishment of one undertaking.

If the present rate of progress continue unchecked, the Canal, it is calculated, will be opened in 1915. Then will that Isthmus, which has hitherto been a barrier between two oceans but has failed to act as a bridge between two continents, be pierced by a waterway capable of floating the largest ships now built or building. Then will the Pacific coasts of the Americas be accessible from 
ports on both sides of the Atlantic without the necessity of a voyage by the Straits of Magellan. Then will the distance from New York to San Francisco be shortened by 8,400 and that from Liverpool by 6,000 miles; the distance from New York to South American ports will be shortened by an average of 5,000 and that from Liverpool to these ports by an average of 2,600 miles: then for the first time Yokohama on the north and Sydney on the south will be brought nearer to New York than to Liverpool or Antwerp, and then will New Orleans and the ports on the Mexican Gulf be brought nearer than New York, by sea, to San Francisco, South America beyond Pernambuco, Australia, and Japan.

No one who cares to know the greater things which are shaping the world can now afford to be ignorant of what is happening on the Isthmus of Panama. In the former days of unstable companies the student of affairs might decline to occupy himself in the study of an undertaking of which the fruition was doubtful. Now, however, that 


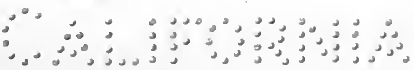

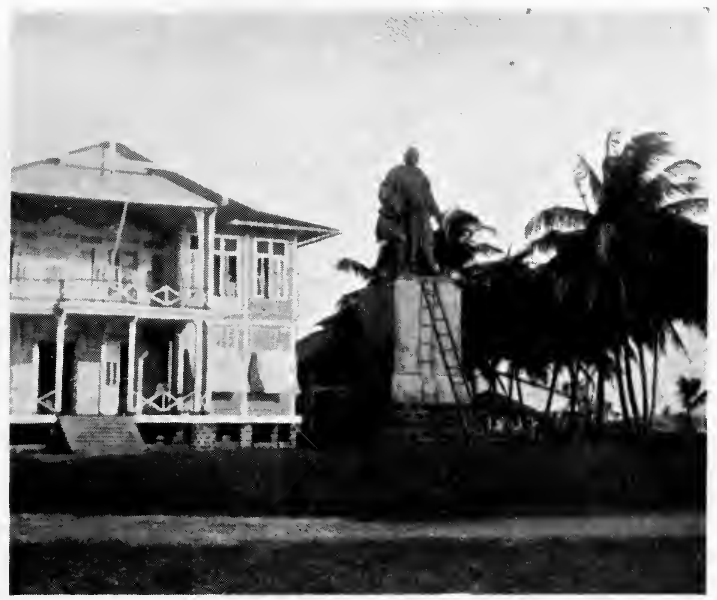

STATUE OF COLUMBUS, CHRISTOBAL, COLON.

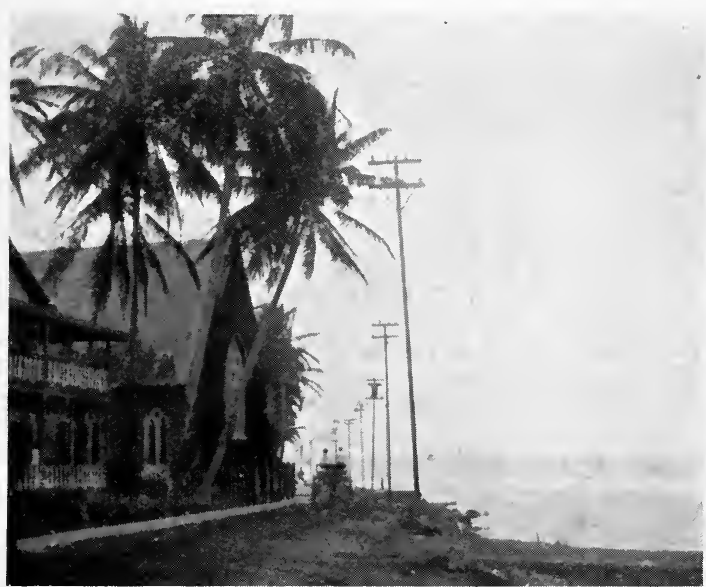

CHRISTCHURCH, COION.

[To facc page i8. 


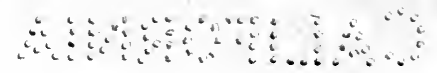


the Government of a great nation have put their hands to the plough the furrow will be driven through. The United States have acquired complete ownership and control of the Canal and of a strip of land five miles wide on either side, called the Canal Zone. The small State of Panama, in which this zone is situate, has placed itself under the protection of the United States. The Government of Great Britain has by a treaty ratified in 1901 waived the treaty right which it formerly enjoyed to share with the United States the control of any trans-Isthmian canal. The Isthmus has been freed from those pestilences which were the greatest obstacles to human effort, and the engineering difficulties are no longer beyond the scope of modern science.

Having first visited the Canal works at the beginning of 1907, I decided to make upon the spot a careful examination of the whole undertaking. For this purpose I visited Washington and made application through the proper channel to the Depart- 
ment of State, which kindly consented to further the inquiry. A set of the published documents was supplied to me, and I proceeded from New York to the Isthmus by the R.M.S.P. Magdalena, arriving at Colon April 12, 1908. Here Colonel Goethals, chairman of the Isthmian Canal Commission, provided me with a letter to those concerned to furnish all information, and proposed that I should make my way about unattended and pursue my inquiries independently. I was thus enabled to converse with perfect freedom with the rank and file, while drawing freely on the special information possessed only by the heads of departments.

For the benefit of readers in England I may explain that these circumstances were to me of especial importance on account of the doubts thrown by American writers, and also by Americans of repute in conversation, upon the reliability of official and other information supplied to the American public on the burning topic of the Isthmus. As an Englishman, and therefore standing outside American party politics, and as a 
scientific student not engaged in commerce or political life, I came to the study of the subject without prepossessions. This at least was my happy state when I arrived in Washington in March last. When I left for the Canal Zone a month later I was filled with gloomy forebodings that I might after all find a rotten state of affairs on the Isthmus. It was with intense relief that I found that I had what is called in America "an honest proposition" to deal with. As my doubts hitherto had been due to the patriotic anxiety of their compatriots, I am sure Colonel Goethals and his colleagues will forgive me for this frank statement of my difficulties and their solution.

Any Englishman, accustomed to see the work of our own soldiers and civil servants in the Crown Colonies or in Egypt, would recognise in the officers of the corps of Engineers and of the Army Medical Corps who are in charge of the Canal Zone men of a like high standard of duty. As this account is written not only for my own countrymen but also for readers on the 
other side of the Atlantic, I should be glad, if it be possible, to convince of my own bona-fides those anxious patriots who find it difficult to believe any good report from Panama. It may tend in this direction to state that I travelled and sojourned at my own charges, and that I went out on an independent inquiry. That I had promised to give an account of the Canal works to my brother geographers in London was my only undertaking, and the acceptance of a free pass on the Panama Railway my only financial obligation either in Washington or on the Isthmus.

In order properly to understand the present and future of the Canal undertaking, it is necessary to give a short account of the history of Isthmian communication, for the conditions which now face the American Government and the Commission are not solely due to present physical causes, but also to previous events. 


\section{HIS'TORICAL REVIEW}





\section{CHAPTER I}

\section{HISTORICAL REVIEW}

THEE conquest of Constantinople by the 1 Ottoman Turks in 1453 completed their capture of the trade routes between Western Europe and the East Indies. The East Indian trade had long been a source of great enrichment to European merchants. It was especially suited to the restricted carrying power of those times, the products (such as pepper) being small in bulk and high in price. The maritime nations therefore sought sea routes to the Indies in pursuit of this trade, and it was Columbus himself, in his efforts to open up a western route to the Indies and China, who discovered the Bay of Limon in 1497. He and his successors sought for a strait or channel 
which should open the way to the East Indies. Cortes sought for the strait in Mexico. Others sought as far north as the St. Lawrence, which was supposed to afford a route to China. No opening could, however, be found nearer to the Equator than the Straits of Magellan (1520), and the hopes of a short route westward to the Indies were disappointed. An Isthmian canal was talked of even in the days of Charles V. of Spain to open the route to the East Indies. In those days of small vessels, the river channels would have served for a great part of the traverse, so that the scheme was not so wild as it may seem.

The purpose, therefore, of the first proposal for piercing the Isthmus was for shortening the distance to the Indies and China. The discovery of the nearer riches of Peru, however, illustrated the fact that the Isthmian barrier has its uses as well as its inconveniences. Porto Bello and Panama were fortified, ships were launched from the latter port for the Peruvian traffic, the treasure was carried across the Isthmus under 


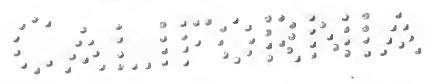

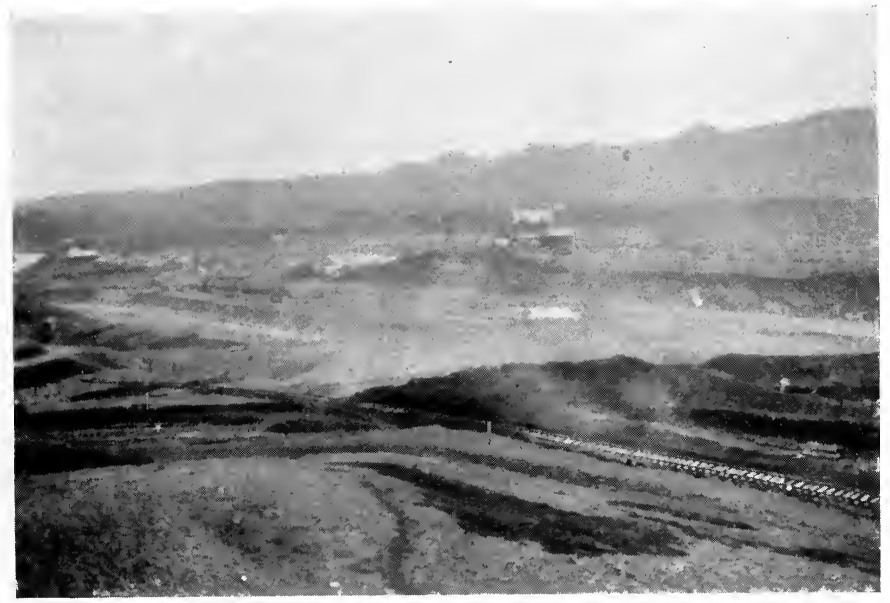

LOCK ANT DAM SITE, GATUN.

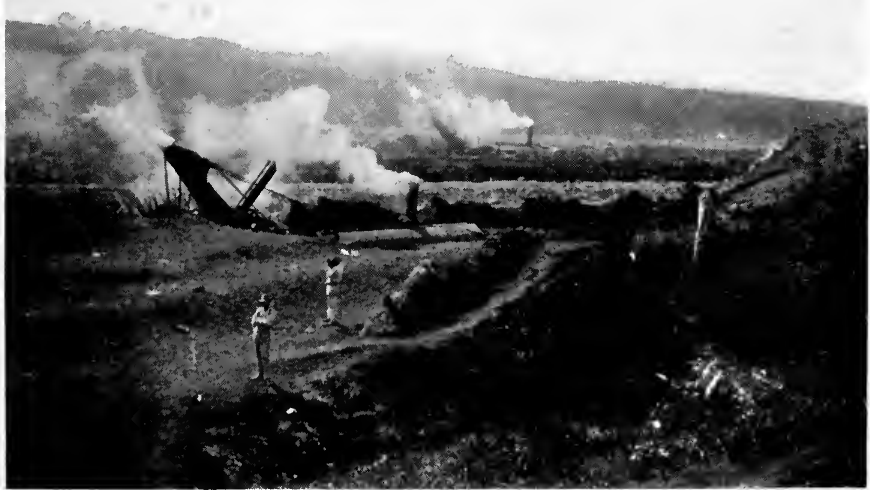

FXCAVATION FOR LOCKS, GATUN.

[To. face page 26. 


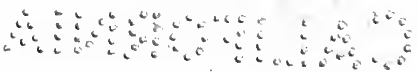


escort and shipped to Spain. The treasureships, indeed, were liable to attack on the Caribbean, but the Isthmian barrier proved an important safeguard to the Peruvian possessions of Spain.

In the next century, the seventeenth, the importance of the Isthmian land route declined, owing to the fact that Spain was no longer able to secure even moderate safety for her ships on the Caribbean. In the present days, when the importance of naval power is so well understood, it is hardly necessary to enlarge upon the significance of this fact, and its bearing upon the problems presented by the Panama route to-day. The project of an Isthmian canal for the purpose of trade between Europe and Asia continued to be agitated, but the inducements were inadequate to overcome the obstacles.

In the midale of the nineteenth century, for the second time, it was the need of improved communication between the east and west of the American Continent which provided a sufficient inducement to improve the Isthmian route. 
At this time the Government of the United States were much occupied with projects of trans-Isthmian communication, particularly by canal, not with a view to Transpacific commerce, but with the object of improved communication between the east and west of their own territory.

In 1846 a treaty was made with the State of New Grenada (afterwards Colombia) with a view to providing facilities for transport in the war between the United States and Mexico. In its most important provision it is similar to the present treaty between the United States and the new Republic of Panama, viz., the United States guarantee the sovereignty of the State in question over the Isthmian territory. Hence the Isthmus was thus early constituted a Protectorate of the United States.

But at this time it was generally thought that Lake Nicaragua provided the best route for a trans-Isthmian canal.

The Pacific seaboard having recently acquired importance to the United States, the Government desired to further the canal 
project on that account. The only practicable Atlantic terminal of a Nicaraguan canal lay within territory over which Great Britain had long exercised control. Further, the Pacific Coast of Canada had recently acquired importance to the eastern provinces and to the home country, and access thereto was extremely difficult. The outcome of these circumstances was the conclusion in 1850 of the celebrated Clayton-Bulwer treaty between the United States and Great Britain, which was duly ratified by Congress. By this instrument it was agreed that neither Government should ever obtain or maintain for itself any exclusive control of any canal connecting the Atlantic and Pacific Oceans, nor erect fortifications commanding the same.

This treaty remained in force until 1901, and I shall have to refer to it again. Meanwhile the great rush of gold-seekers to California had supplied the needful stimulus to a scheme, already mooted, of an Isthmian railway terminating at Panama. In spite of the enormous difficulties entailed by the pestilential climate, the undertaking was 
completed in 1855. This achievement, originating in New York, was the work of W. H. Aspinwall, Henry Chauncey, and John L. Stephens.

It was undertaken independently of any canal scheme, but it exercised a profound effect upon the fate of subsequent schemes. The facilities which the railway afforded determined de Lesseps's choice of route, and de Lesseps ploughed so deeply that those who came after him have found themselves constrained to follow his furrow. The "New World" is in fact no longer new, and its statesmen now have to solve problems presenting historical as well as physical factors.

The American Civil War interrupted the prosecution of canal schemes, but the examination of routes was recommenced by the United States Government in 1866, a Commission finally reporting in $1876^{*}$ in favour of the Nicaraguan route.

In 1869 the Suez Canal was opened for traffic. Immediately, the route by Panama ceased to be the shortest from Europe to

* The report, however, was not published until 1879. 


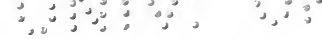

, 年, :

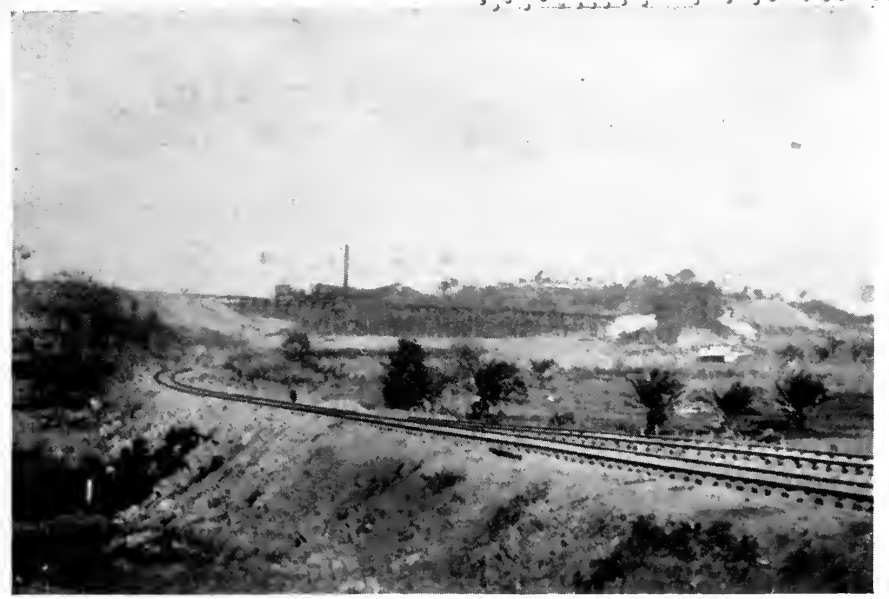

RE-LOCATION OF RAILWAY ABOVE GATUN.

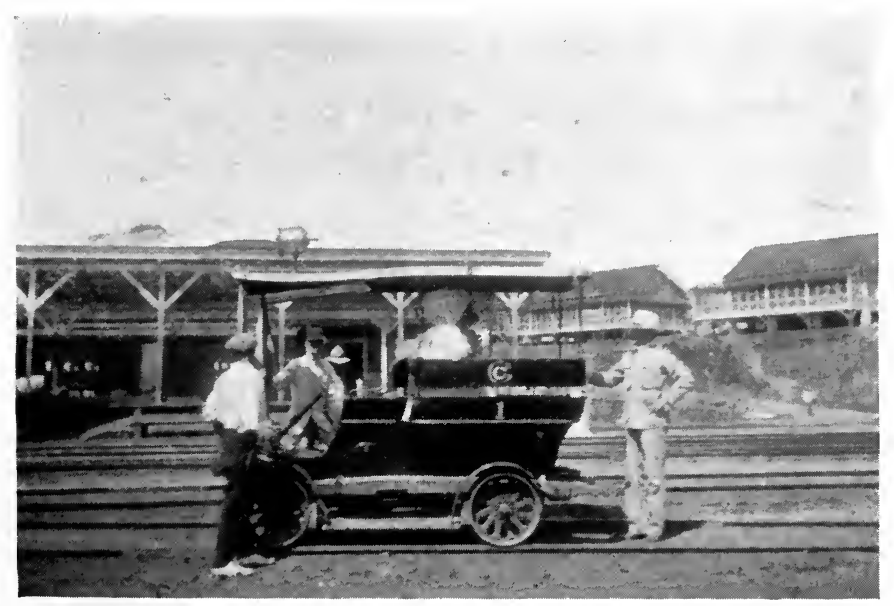

MOTOR TROLLEY FOR INSPECTION OF WORKS.

[To face page 30. 

any part of the East Indies. The importance of that route to Asia was thus greatly reduced as far as Europe was concerned, but, relatively, its importance to the United States was increased, for the Suez Canal does not shorten the Asiatic voyage from New York, Boston, or New Orleans to the same extent as it does for European ports.

The Old World bad been severed into halves by the enterprise of one man, and that man no potentate, but merely one possessing the gift of persuasion. By his achievement, which was immediately crowned by financial success, Ferdinand de Lesseps suddenly became possessed of powers such as are not always at the disposal of the Governments even of great countries. $\mathrm{He}$ decided himself to sever the barrier between the Atlantic and Pacific Oceans, convened a "Congress" at Paris in 1879, and inaugurated in 1881 the Compagnie Universelle du Canal Inter-océanique de Panama. $\mathrm{He}$ had decided to adopt the Panama route on account of the facilities afforded by the railway. The money was mainly subscribed 
in France. The American railway company was bought out at the enormous price of $\$ 25,500,000$, and in the course of the next eight years a large part of the work required for a tide-level canal was well executed on sound lines by the genius of the French, who are excelled by none in the arts of the civil engineer. The exact proportion which the French work bears to that since accomplished by the American Government will be shown later. The engineers now on the Isthmus are full of praise for the work of the French engineers, and their wonder daily grows both at its quantity and its ingenuity. It is only those at a distance, or ill-informed, who have belittled these achievements. Unfortunately, the French engineers were not properly supported. De Lesseps, if he were ever a practical man, had certainly ceased to be so since his first great success. A practical man is one who counts the cost of everything he is about to do. De Lesseps no longer counted cost. He had become as one believing in his star. His actions remind 
us of those of some of the great conquerors whose early successes have led them to undertake impossible campaigns. The question has been discussed if any human character can stand more than a certain share of success and yet retain a sound judgment. Certainly the character of de Lesseps was not equal to the strain. The expenditure was awful - $\$ 300,000,000$ in eight years, i.e., more than three times the sum for which the Suez Canal was constructed. The Company went into liquidation in 1889. Much had been embezzled. Much, it is said, had been spent in purchasing the silence of voices which would otherwise have been raised against a Europeanised canal.

The affairs of the Company were, taken over by the New Panama Canal Company, whe continued to administer the railway, and, with small means, did excellent work for the next twelve years in keeping the machinery and the works from deterioration, in excavations at the summit, and above all in extending the scientific examination of 
the country so as to obtain much-needed data for the construction of the high-level canal which was now proposed in place of de Lesseps's project of a tide-level waterway.

In 1869 President Grant, in a message to Congress, had recommended the construction of an Isthmian canal under the sole control of the United States, and popular opinion since that time, if not before, has always strongly held that if a canal be made it should be exclusively under that control. It was not the least of de Lesseps's imprudences that he proceeded with his project in spite of warnings on this matter. In 1898 an event occurred which made the American nation feel that an Isthmian canal was necessary, and that it must be under their exclusive control. At the outset of the war with Spain, the Oregon, one of the best of America's small fleet of battleships (we write of ten years since), was lying in the Pacific. She had to steam more than 13,000 miles to reach Key West, and the whole nation was in a state of nervous 
tension for many weeks pending her junction with the main fleet.

It seemed at the time that the Panama route could hardly be obtained for a canal under purely American control, and a further investigation of the Nicaraguan route was ordered-that route which had been preferred by the American experts before de Lesseps intervened. The New Panama Canal Company had by this time brought their labours to the point where it seemed practicable to appeal to the investing public of the world for funds to construct a high-level Panama canal. To do this in the face of a Nicaraguan canal, undertaken as a national affair by the United States, would have been hopeless: they therefore laid their detailed plans before President McKinley. A Commission was accordingly appointed by Congress to inquire into the best route for an Isthmian canal " under the control, management, and ownership of the United States." * The report was presented to Congress on

* Act of Congress approved by President, March 3, 1899, Commission appointed June 10. 
36 THE PANAMA CANAL AND ITS MAKERS

December 4, 1901, rather more than two years later, and is a document of great historical and scientific interest. The quarto volume of 688 pages is accompanied by a portfolio of 86 maps, plans, and panoramic views. The last of these, showing the mountainous skyline of the Isthmus east of Colon, with altitudes marked, illustrates in a striking manner the conclusion of the Commission that the San Blas route, or any route east of Colon, would involve a ship tunnel. These routes are dismissed as impracticable on account of the altitude of the divide. The Nicaraguan and Panamanian are found to be the only practicable routes, and the details of both are fully discussed. The high-level canal was preferred by the Commission to the sea-level at Panama, and on the Nicaraguan route only a high-level canal is possible, so that in this respect the two routes were considered to be on a par.

The relative advantages of the two routes are carefully set out in the report, the general tenor of which is favourable to that by Panama. Nevertheless, the Commission re- 


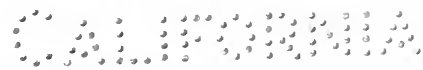

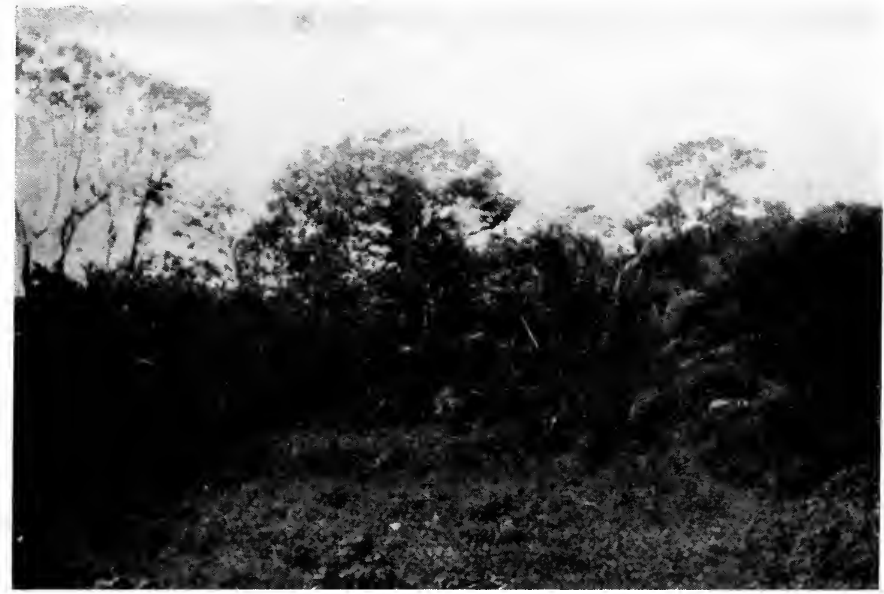

TROPICAL FOREST, WITH PARASITIC GROWTHS.

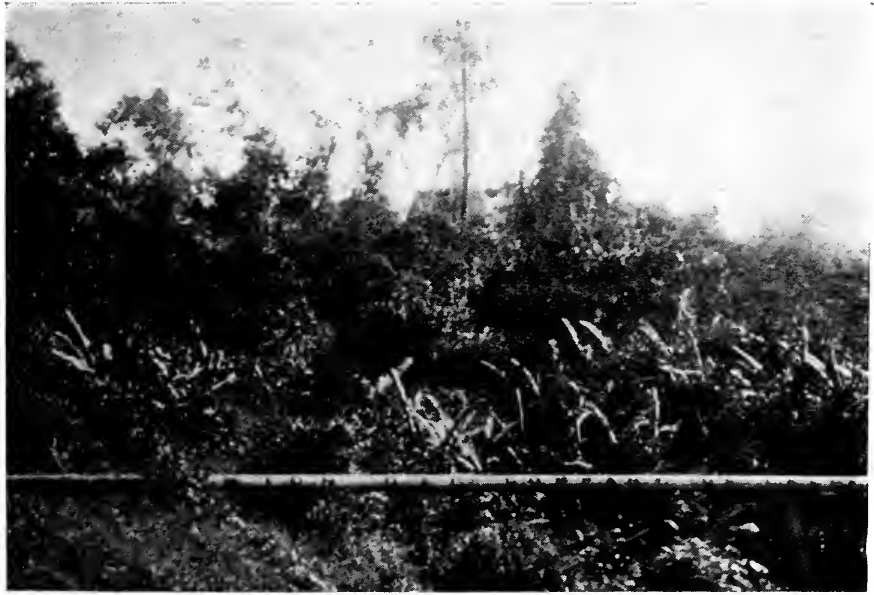

PIPE CONVEYING OIL ACFOSS THE ISTIMIUS.

[To face page 36. 
县 
commend that the Nicaraguan route be adopted, on account of the excessive valuation which, they state, was placed by the New Panama Canal Company on their works and property. The value of these, including the Panama Railway, was estimated by the Commission at $\$ 40,000,000$. The New Panama Canal Company, learning that the Commission had thus reported, cabled an offer to sell at this price, and the Commission accordingly sent in a supplementary report in favour of the Panama route. By June 28, 1902, the "Spooner" Act had been passed and ratified, authorising the President to purchase the canal works at this price, and to acquire from the Republic of Colombia the necessary rights for the control of a Panama canal, then to be constructed; but in the event of his not being able to acquire such control, then to proceed with the Nicaraguan project.

Meanwhile, by the Hay-Pauncefote Treaty, ratified by the Senate December 16, 1901, Great Britain had waived the right of joint control of any Isthmian canal which she 
had held since the ratification of the ClaytonBulwer Treaty in 1850. It remained therefore only to negotiate a treaty with Colombia. The treaty of 1846 with New Grenada afforded a precedent as far as the question of control was concerned, and the negotiations appear to have been related mainly to the question of price. A treaty was negotiated by officials of the two Republics, by which the United States was to pay a sum of $\$ 10,000,000$ to Colombia, and after nine years an annual sum of $\$ 100,000$. This was confirmed by Congress but rejected by the Colombian Senate, and negotiations came to an end with the adjournment of that body, October 31, 1903.

Three days later the Province of Panama renounced its allegiance to Colombia.

Another three days, and the independence of the New Republic was recognised and guaranteed by the United States.

In less than a fortnight afterwards a treaty was signed at Washington by which the United States acquired complete ownership and control of the proposed canal for the 
sum of $\$ 10,000,000$ and an annual payment of $\$ 250,000$, to commence nine years afterwards. This treaty was ratified at Panama December 2, 1903, and by the United States Senate February 23, 1904.

One significant point must be mentioned with reference to the Panamanian revolution. The inability of Colombia to make an effective effort to assert its power on the Isthmus was due to naval weakness in the absence of communication by land. No army could march through the tropical forests which still isolate the Canal Zone from South America, and control at Colon and Panama still depends upon sea power.

Thus, at last, the United States owns and controls its Canal Zone. We will now state precisely the position in which that nation stands in reference to this matter, and then we may leave the work of the diplomats to consider the task of the engineers.

\section{The National Status of the Canal.}

The position which will be held by the United States in relation to other Powers 
40 THE PANAMA CANAL AND ITS MAKERS

is foreshown in the Hay-Pauncefote treaty with Great Britain and in Article XXIII. of the treaty with Panama. The HayPauncefote treaty is in supersession of the Clayton-Bulwer treaty. The latter stipulated that no fortifications should be erected controlling the Canal. In the Hay-Pauncefote treaty this clause is omitted. On the other hand, it is stated in Article III., § 2, that "the Canal shall never be blockaded, nor shall any right of war be exercised nor any act of hostility be committed within it." Hence, the reader may have remained in doubt whether the United States Government had intended to reserve to themselves the right to fortify. However, the terms of the subsequent treaty with the Republic of Panama answer this question, for after stating in Article XVIII. that the Canal shall be opened in accordance with all the stipulations of the treaty of 1901 with Great Britain, Article XXIII. states that "the United States shall have the right to establish fortifications."

As a matter of fact, such fortifications 
are to be constructed, and the plan of the Canal has been adjusted to the requirements of military defence.

There have been, among public men in the United States, two schools of thought on the vital question of the defence of the Canal. One school has held that the best safeguard was to be obtained by leaving the Canal unfortified (as is the case with the Suez Canal), and by the establishment of a general Convention, by which all the Powers, including the United States, should bind themselves to respect the neutrality of the Canal and leave it inviolate. Other public men preferred forts, guardships, and a garrison. The general public in the United States, on the other hand, appears to have unanimously held that an international guarantee would be ineffectual and, moreover, derogatory. As we have seen, the popular view has prevailed, but traces of the antagonistic and incompatible notion of internationalisation remain in the language of the treaties. This is not surprising when we recollect that the first draft of the Hay- 
Pauncefote treaty was drawn up with a view to neutralisation, according to the precedents afforded by the Suez Canal. Thus we find that Article III. commences with the words: "The United States adopts as the basis of the neutralisation of the Canal ..."; and in Article XVIII. of the treaty with Panama we find: "The Canal when constructed, and the entrances thereto, shall be neutral in perpetuity. ..."

What then are we to understand by the term "neutral" as applied to the Panama Canal in war time? I suppose the meaning to be that if there be a war to which the United States is not a party, the Canal will be used by belligerents in exactly the same way as was the Suez Canal, e.g., in the RussoJapanese War, and that the Government of the United States has pledged itself to see that such neutrality is preserved. But if there be a war in which the United States is a party, the circumstances of fortification and operation by the United States in fact render it impossible for the other belligerent to use the Canal, and are 


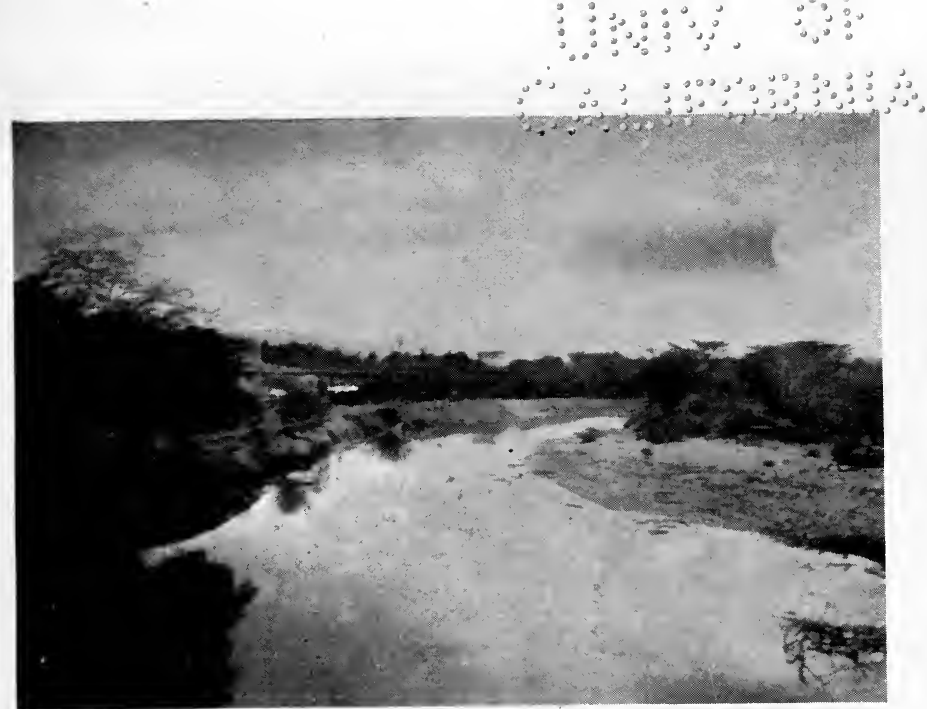

CHAGRES RIVER NEAR BABARCOES.

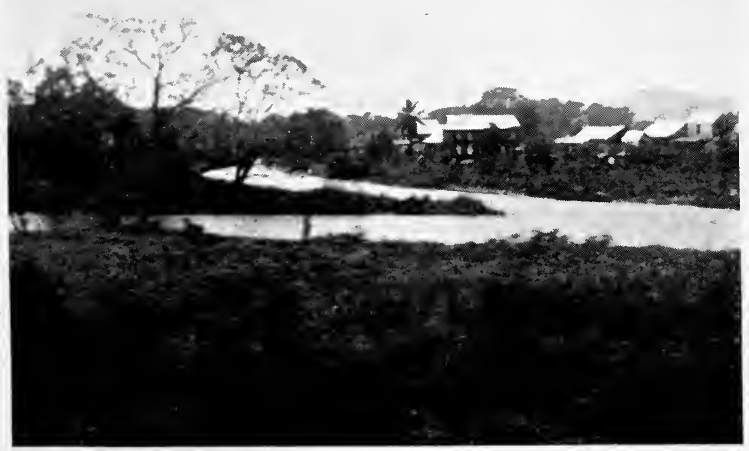

CHAGRES RIVER NEAR OBISPO.

[To face page 42. 
astond 
intended * to have that effect. This being so, the United States is preparing to defend the Canal from attack. Thus it is important to the proper understanding of the undertaking on which the United. States Government has embarked that we should clearly realise that the Canal is only neutral in a restricted sense.

The commercial status of the Canal, however, is similar to that of Suez, in that by Article III., $\S 1$, of the Hay-Pauncefote treaty, "The Canal shall be free and open $\dagger$ to the vessels ... of all nations ... on terms of entire equality, so that there shall be no discrimination against any such nation, or its citizens or subjects, in respect of the conditions or charges of traffic, or otherwise."

* See Report of Canal Commission, 1897, p. 168.

† In Article XVIII. of the treaty with Panama this clause is cited, with the addition "and the entrances to the Canal." 

ON THE CANAL AS IT IS TO BE 



\section{CHAPTER II}

ON THE CANAL AS IT IS TO BE

$B_{\text {American Isthmus is about } 36 \text { miles }}^{\text {ETWEEN Colon and Panama the }}$ across as the crow flies, and is therefore nearly, though not quite, at its narrowest. In this portion of its sinuous course both coasts trend north of east and Panama lies nearly south-east of Colon. The Isthmus in general is a very confused mass of hills and mountains. It is crossed by no transverse trench (such as sometimes occurs in mountainous regions), neither by the trough provided by down-folded strata, nor the rift valley produced by fracture and foundering of rock. A low-level transverse can only be found by following up the course of a river, crossing the divide, and following the 


\section{THE PANAMA CANAL AND ITS MAKERS}

course of another river downwards to the other ocean. From the vicinity of Colon, by following up the valley of the River Chagres, we are led in precisely the required direction, i.e., directly towards the Pacific, for nearly two-thirds of the way. The distance from the head of Limon Bay, following the curves of the valley, is 26 miles to this place, Obispo, and for the greater part of the distance the river flows in a broad valley of deep alluvial deposits.

At the point mentioned, the Chagres abruptly changes its course, and, if followed towards its source, will be found to be flowing from north-east to south-west. Moreover, it is now confined to a narrow valley, with steep hills of rocky substance on either side, and its gradient becomes much greater than hitherto. The course of the Canal cannot therefore follow the Chagres valley further. Fortunately, the valley has led us not only a long distance towards the Pacific, but to a place where the dividing ridge only attains an elevation of about 300 feet above sea-level. Striking from Obispo 


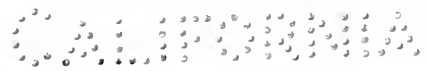

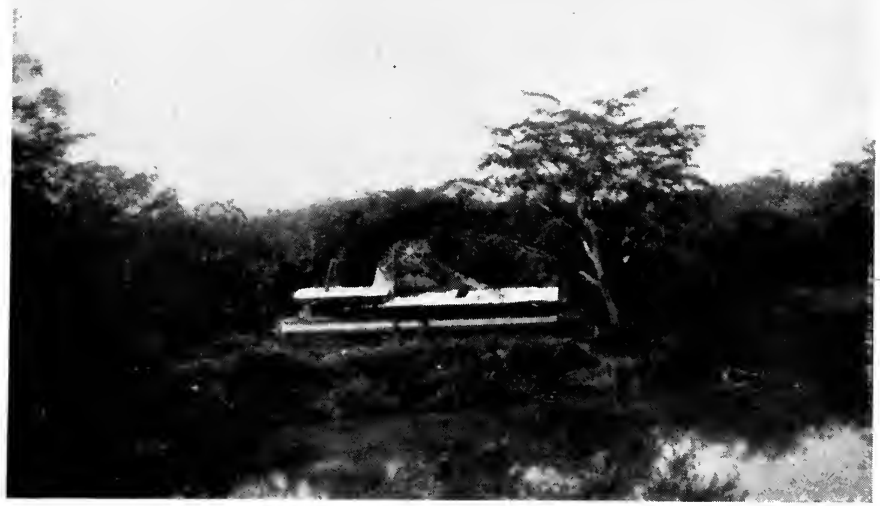

FRENCH DREDGER TAID UP.

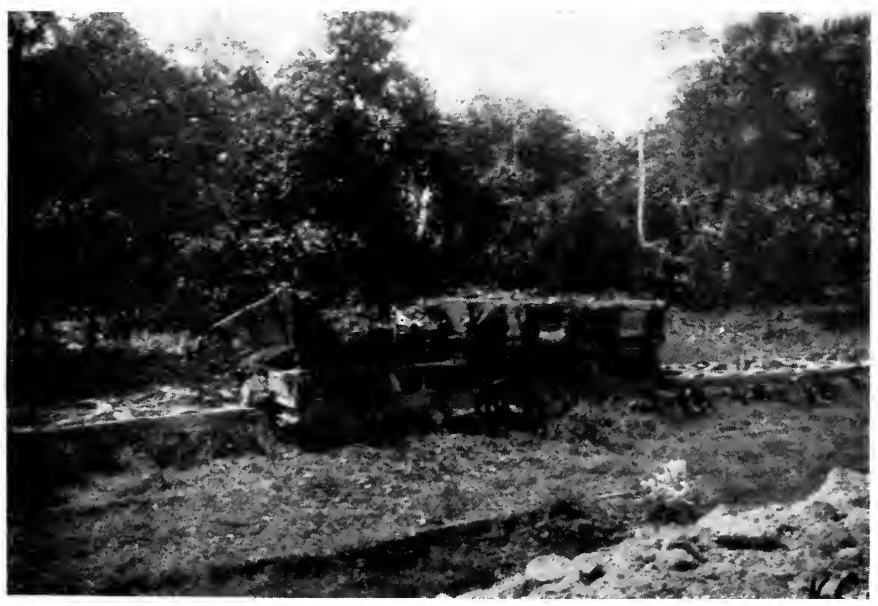

- ABANDONED FRENCH TRUCKS.

[To facie page t $^{8}$. 

straight for the Bay of Panama, we come in 9 miles to the low alluvial plain of the Rio Grande, which leads straight to the sea in another 6 miles. Thus, from shore to shore, the course of the Canal along this route is 41 miles; but to reach deep water $4 \frac{1}{2}$ miles must be dredged beneath the sea at either end, so that the total length of the artificial waterway is 50 miles. Of the land-course less than a quarter, or about 9 miles, is hill country, and most of this is less than 200 feet above the sea. The United States has been committed to this route by the long chain of circumstances already narrated.

Whatever type of canal was to be constructed along this route, there were certain excavations which must necessarily be done. These were, firstly, dredging the sea channels, and secondly, making a cut through the solid rocks of the divide. Thus, although de Lesseps started operations upon inadequate data, yet most of the work done by the first Panama Canal Company is available, either for the tide-level canal proposed 
by de Lesseps or for the 85-foot-level canal now being made by the United States. Similarly, the New Panama Canal Company, although hampered by many uncertainties, continued to work at the Culebra Cut, as it is called, that is to say, the trench through the rocky hills which separate the alluvial valleys of the Chagres and the Rio Grande.

Thus the works taken over by the United States in 1904 were available for any type of canal, and the decision to adopt the 85foot-level was not taken until 1906. Even now, or in April, 1908, at the time of my visit, when so much work has been done upon the locks, many of the rank and file of the employees still cherish the hope of a tide-level canal, and there are not wanting well-informed people, both on the Isthmus and in the States, who, while accepting the high-level scheme as inevitable, regard a tide-level canal as essentially a better thing.

Let us resume our description of the Isthmus, in order that we may be in a 
position to understand the conditions with which the engineers have to deal. The practicability of the Panama route is due to the fact that rivers have already done a great part of the excavation, and if desert conditions had supervened-if there were, as at Suez, practically no rainfall-the construction of a tide-level canal would be simply the excavation of a trench in dry material, which would be filled by the inflowing waters of the sea. A tidal lock being added to regulate the ebb and flow at Panama (for the Atlantic side is tideless), the canal would be complete.

But as things actually are, the rainfall on the Isthmus is very heavy, particularly on the Atlantic side, where it reaches 140 inches* per annum, and the rivers have at all times considerable bodies of water, and during the rainy season (commencing in May) are subject to sudden and violent freshets. The Chagres at Gamboa has been known to rise $35 \frac{1}{2}$ feet in 24 hours. $\dagger$ Suppose then

\footnotetext{
* Abbot, "Problems of the Panama Canal," p. 96.

$\dagger$ Loc. cit., p. 146.
} 
that a tide-level trench were suddenly formed across the Isthmus, as by a convulsion of nature. We should then see the rivers pouring into this fjord in a number of cascades of various height. Of these the greatest would be the Chagres cascade, entering from the east near Gamboa and Obispo. The height of the waterfall would be 46 feet in the driest season and as much as 80 feet in occasional floods.*

In order therefore to make a tide-level canal, some means must be found for disposing of the waters of the Chagres and other rivers. De Lesseps's tide-level project was rather an aspiration than a plan. He proposed to conduct the waters of the Chagres to the sea by other channels. The magnitude of this task would be scarcely less than that of cutting the Canal itself. The other rivers on both sides of the Canal would likewise require diversion channels, so that the final result would be roughly the formation of three channels, of which the centre one would be for navigation. The Board of Con* Abbot, loc. cit., p. 116. 


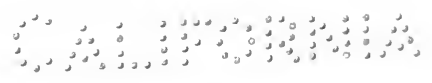

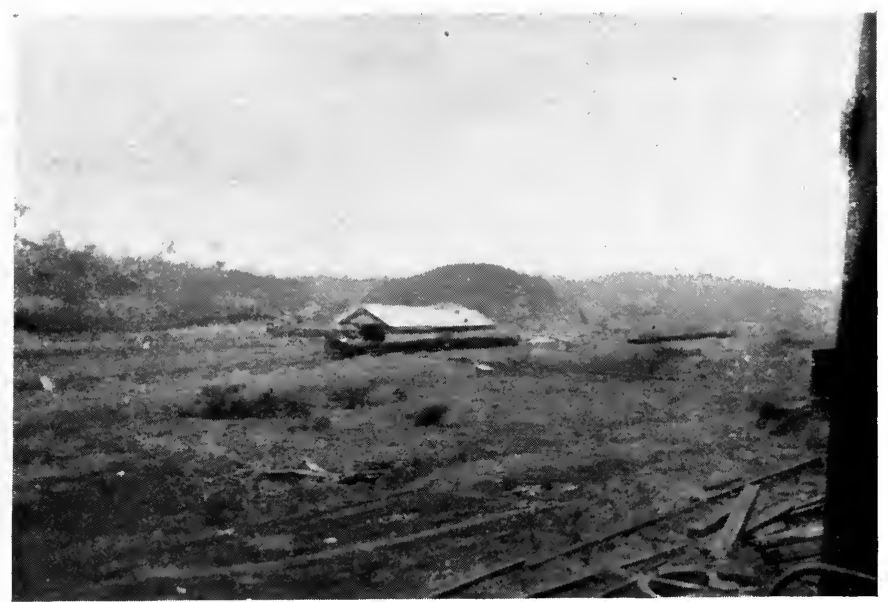

EXCAVATIONS NEAR TAVERNILLA.

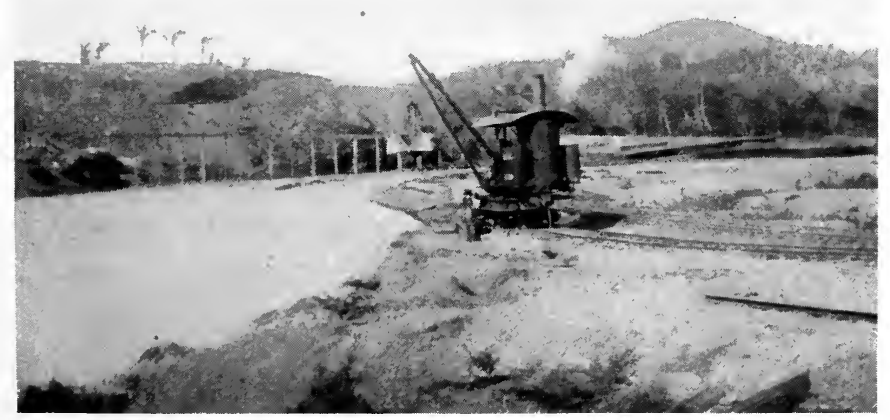

RAILWAY AND RIVER NEAR GORGONA.

「To face page 52. 
$\therefore 5$ 
sulting Engineers summoned by President Roosevelt in 1905 to advise the Isthmian Canal Commission recommended, in a majority report, a tide-level canal as practicable and best fulfilling the national requirements, defined by the Spooner Act of 1902 . But whereas they had detailed schemes for high-level canals before them, they were in the matter of the sea-level project at the disadvantage of having to act in a constructive capacity and elaborate the details of a scheme before they could criticise it. Moreover, five of the eight who constituted the majority were European engineers, who returned to their duties as soon as the report was drafted. The report of the minority in favour of the 85-foot-level scheme having been adopted by Congress in 1906, all available engineering talent has for the last two years been devoted to improving the details of this scheme. The tide-level project of the majority of the Board has had no such advantage, and the difficulty of estimating the relative advantages of the two schemes is therefore all the greater. 
Both schemes depend for their success upon the security of dams.

The tide-level scheme has a dam at Gamboa, near Obispo, thus making a lake of the upper waters of the Chagres, whose surface would be 200 feet above sea-level.* The floodwater would partly be accommodated in the lake by reason of the great height of the dam above low-water stage, and partly by running the excess into the Canal, by which it would escape to the sea, generating currents which the Board calculated would not attain an injurious velocity.

Streams entering the Chagres in its lower reaches would be dammed back or diverteda considerable, but not momentous, undertaking. The three great objections to the scheme appeared to be:-

1. The extra cost, and above all the extra time, required to complete the immensely greater quantity of excavation required for the last 85 feet;

2. The fact that the artificial lake was to be above the Canal, so that, if the dam burst, the Canal might be ruined; and,

* Report, Board of Consulting Engineers, p. 205. 
3. That the velocity of currents in the Canal due to discharge of the surplus waters might perhaps be a serious drawback to navigation in a narrow channel.

It will be seen presently that the second disadvantage is offset by corresponding disadvantages in the dam required for the highlevel canal.

As for the cost, that has always been an unknown quantity, and, I think, has always been a secondary consideration. The fear of undue delay seems to have been the principal deciding factor in favour of the high-level scheme. Rival expert opinions that the majority of the Board of Engineers had under-estimated the time required for the tide-level canal were adopted by those in authority, and mainly on this account, I think, the high-level scheme became law.

Since visiting the Isthmus a second time, and inspecting the work in the great Cut between Empire and Paraiso, it has seemed to me that there is an objection to the tidelevel project which did not fully appear in 
the early stages of the work, viz., that the behaviour of the rock might involve the engineers in ever-increasing difficulties as the depths increased. The opinion which had been held by many that the difficulties would diminish with the depth did not seem to me to be justified up to that time.

Next let us see what are the special difficulties of the high-level project.

This also depends for its success mainly on the efficacy of one dam, which is now being made at Gatun. It will hold up the waters not only of the Chagres but of its tributaries, to a level of 85 feet above mean tide, and the area of the lake thus to be formed is shown on the map. The Chagres will be ponded back far above the point where it enters the Canal, and thus will be effectually tamed. The flood-waters will be spread over an area of about 164 square miles-for Lake Gatun will be twice the size of Lago Maggiore and about fourfifths that of the Lake of Geneva,* and ships,

* The size, in fact, will not differ greatly from that of the principal basin of the Lake of Geneva, all above the 


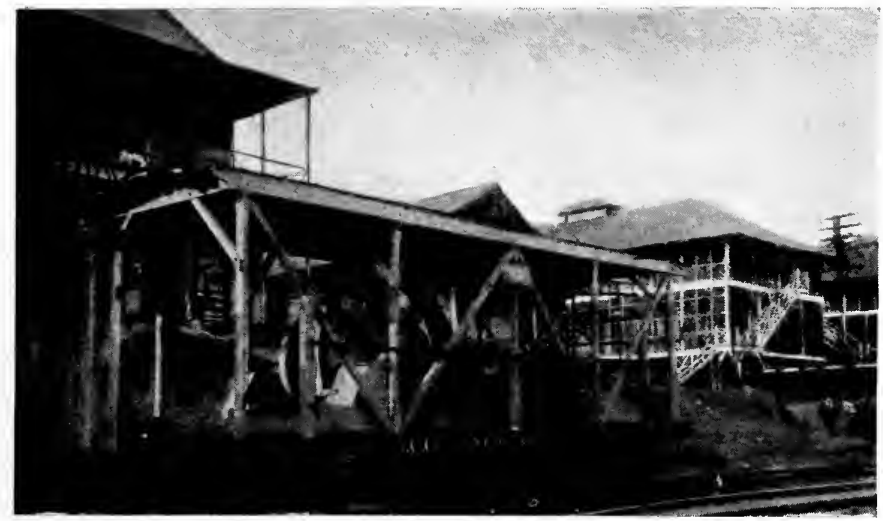

LIDGERWOOD WINDING APPARATUS.

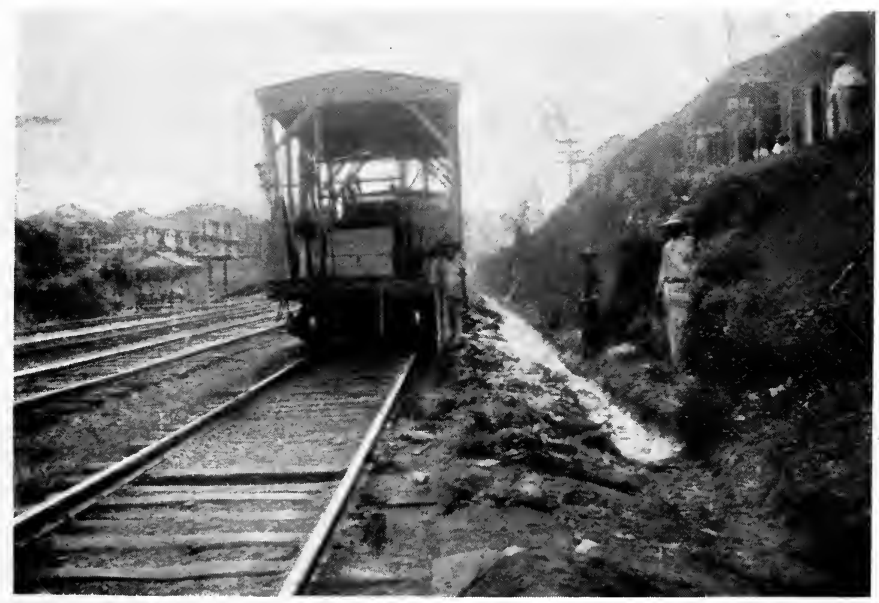

ANOPHELES BRIGADE OILING A DITCH.

[To face page $5^{6}$. 


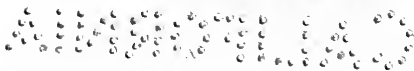


in the ample waterway, will not be troubled by currents.

A flight of three locks at Gatun will raise ships to the level of this lake in coming from the Atlantic, and one lock at Pedro Miguel and two at Milaflores will lower them to the level of the Pacific.

It has been claimed that if the Gatun dam burst the consequences would be-less disastrous than if the Gamboa dam burst, but there is in reality little to choose between the two catastrophes.

The great blot on the high-level scheme is that the great Gatun dam is not founded on solid rock. The Gamboa dam of the tide-level project would have been founded throughout on hard rock, from which it could have been built up of masonry so that the structure should be part and parcel of the rocky framework of the globe itself. The Gatun dam as recommended in the minority report, on the other hand, was petit lac, or narrow part at the Geneva end. A good idea of this area is obtained by recalling the well-known view over the waters of this lake from the quai at Ouchy. 
designed to consist essentially of a mass of earth dumped upon an alluvial plain so as to fill up a gap of 2,000 yards between two ranges of hills, the gap through which the Chagres escapes to the Atlantic. Thus the Gatun lake was to be held up as a glacier lake is held by a moraine blocking a valley.

We shall presently describe the high-level canal as it is to be, from which it will be seen that it will provide a magnificent waterway, but before concluding the present section I must mention the special point in which it will be inferior to a tide-level canal. This is for purposes of defence. A fortress has to be preserved from capture, but not from damage. The locks, however, must be preserved from serious damage, which demands far more elaborate protection. Such protection, moreover, has to be provided at two positions (Gatun and Milaflores) about 30 miles apart.

The High-level Canal as it is to be.

The Spooner Act, the law under which the Canal is being constructed, enacts that 
it shall be "of sufficient capacity and depth as shall afford convenient passage for vessels of the largest tonnage and greatest draft now in use, and such as may reasonably be expected."

Accordingly the following dimensions have been selected :-

1. A minimum depth of 41 feet.

The Suez Canal has a depth of 31 feet* admitting of the passage of ships with a draft of 27. feet. $\dagger$ The channel of this canal is now being deepened, so that by 1915 it is hoped that a depth of 36 feet + will be obtained. The Kiel Canal has a depth of 30 feet. The average draft of the Cunard s.s. Mauretania, the largest ship now afloat, is about 32 feet, but she is stated to draw, when fully laden, about 37 feet, and there are comparatively few harbours in the world which she could enter fully loaded.

2. A minimum bottom width of 200 feet in the Culebra Cut.

* Report, Board of Consulting Engineers, p. 175.

† "Four Centuries of the Panama Canal," p. 436.

$\ddagger$ Daily Telegraph, June 18, 1908. 
60 THE PANAMA CANAL AND ITS MAKERS

The minimum bottom width, or width at a depth of 31 feet, in the Suez Canal is 108 feet.

The bottom width of the Kiel Canal is 72 feet.*

3. Each lock will have a usable length of 1,000 feet and a width of 110 feet.

The locks of the Kiel Canal have an available length of 492 feet and width of 82 feet.

The Mauretania has a length of 790 feet and beam of 88 feet.

4. The minimum radius of the curves is 5,577 feet (1,700 metres). + This curve, however, does not come in the Culebra Cut, where the bottom width is to be 200 feet, but north of Bas Obispo, where the bottom width is 500 feet. Most of the curves have a radius of 9,842 feet (3,000 metres).

In the Suez Canal, $\ddagger$ outside Lake Timsah, there are five curves with a radius of 2,000

* Report, Board of Consulting Engineers, p. 173.

+ Vide p. 205 of General Abbot's "Problems of the Panama Canal" (1907). Slight changes in the projected course are made from time to time, so that this figure is subject to slight modification.

$\ddagger$ Report, Board of Consulting Engineers, p. 178. 
metres, or a little more, which are being enlarged to 2,500 metres $(8,202$ feet). The usual bottom width in these curves was 184 feet, but this is being increased to about 230 feet. The Kiel Canal has four curves with a radius of 1,000 metres (3,284 feet).

A reference to the accompanying plan (vide Map, end of volume) of the Panama Canal will show that most of the curves are situate in Gatun lake, where the width of the canal proper is large, and where the spread of shallower waters secures better steerage.

Thus the high-level Canal is not only deep and wide, but also much freer from troublesome curves than might be supposed from a casual inspection of its course. The details of the bottom width of the high-level Canal in its different parts are as follows:-

From the Atlantic entrance to Juan

Feet.

Grande (27 miles) $\quad \ldots \quad \ldots \quad \ldots \quad 1,000$

Juan Grande to Bas Obispo $\quad \ldots \quad \ldots \quad 500$

Bas Obispo to a point about half-way

between Empire and Culebra $\quad$... 300

Culebra Cut nearly to Pedro Miguel lock

(about 4 miles) ... $\quad \ldots \quad \quad \ldots \quad$... 200

Pedro Miguel to Pacific entrance $\quad$... 500 
Limon Bay being shallow, the deep water where a battleship can freely navigate or mancuvre lies outside a line joining Colon Lighthouse with Toro Point, and at a distance of $7 \frac{1}{2}$ miles from Gatun locks. From this distance the lock-excavation can now be plainly discerned from the deck of a ship without the aid of a glass. Here, when the Canal is complete, a ship will enter the buoyed channel of the submarine portion of the Canal, but this part of the channel does not lead directly towards the locks, which are not visible upon the face of the water. Moreover, they are presently hidden altogether by the land. Not until Mile 5, near Mindi, is reached does the course of the Canal, by a slight bend, open up the locks to uninterrupted view, and at this point the ship is already confined between banks. When the foot of the flight of three locks is reached a vessel will no longer proceed under her own steam, but be warped through.

The length and width of the locks has already been stated. The maximum lift will be 32 feet, or about 4 feet more than in 


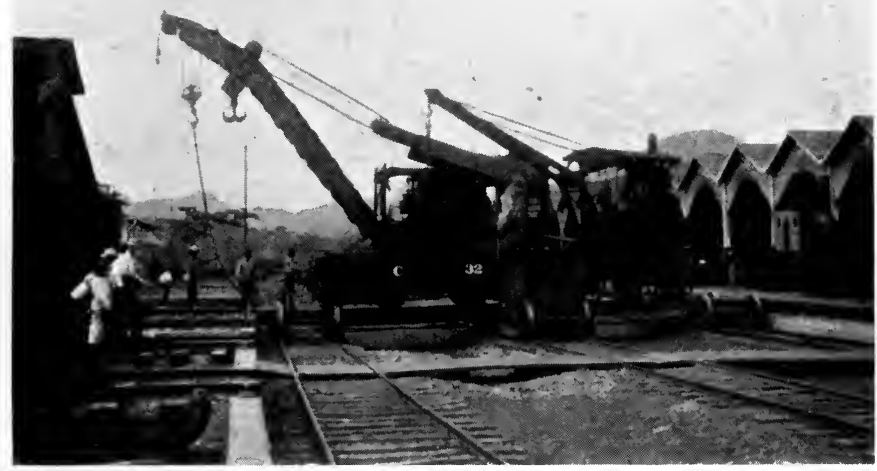

100-TON WRECKING CRANE, GORGONA.

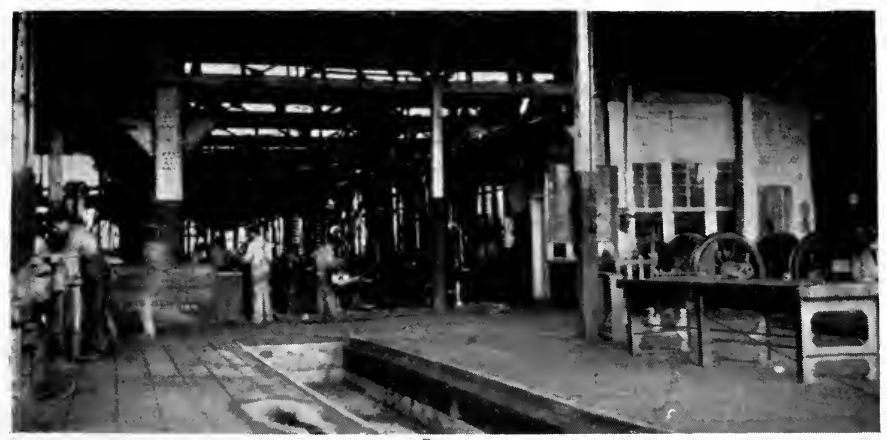

INTERIOR OF MACHINE SHOP, GORGONA.

[To face page 62. 


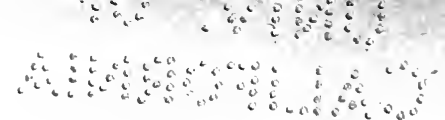


any other locks at present in use. As the width (110 feet) is much greater than that of existing locks, it follows that the lock gates will be far larger than any now in use. The vessel has to pass through a flight of three succeeding locks. Parallel with this is a second flight of three locks, so that two ships could be simultaneously put through either flight in the same, or in opposite, directions. Each lock through which the vessel passes on her upward course is provided with two pairs of mitre gates, i.e., double-swinging doors, but the uppermost lock has in addition a rolling gate near the lower end. This is a precaution against the breaking through of the upper folding doors by a ship coming down, i.e., from the Pacific side. An emergency gate is also being designed, a sort of swing bridge, to close the upper entrance to the flight of locks, for Gatun, Pedro Miguel, and Milaflores. It is hoped that a vessel will be put through all three locks at Gatun in 50 minutes, to which must be added some delay in approaching. Coming from the Atlantic 
b4 THE PANAMA CANAL AND ITS MAKERS

the water of the Canal will be smooth, and the vessel somewhat sheltered, so that there should be no difficulty. Approaching from the lake there may be some roughness, but anything more than a fresh breeze is rare, and the lake will be practically free from currents, so that the approach should present little difficulty. The Pacific side is always calm, so that no difficulty of approach or exit is to be anticipated there on account of either winds, waves, or currents.

Our vessel, having been locked up to the broad surface of Lake Gatun, proceeds under her own steam and at a fair rate of speed across that lake, slowing down to about $4 \frac{1}{2}$ miles per hour for the 9 miles of Culebra Cut, which will thus occupy two of the 8 or 10 hours in which it is hoped to accomplish the whole transit. On this basis it is calculated that 40 ships could be put through in 24 hours from the Atlantic to the Pacific, or two fleets of 20 ships if passing simultaneously in opposite directions.

A 10-hour transit of the 50-mile channel is about the same rate of progress as that 
in the Suez Canal, where, though there are no locks, the speed has to be kept low on account of the friable nature of the banks.

It is evident that the time of transit cannot yet be certainly known to an hour or two, but a considerable margin beyond the above estimate would enable the passage to be made between dawn and dusk of the tropical day.

At Pedro Miguel our vessel passes through one lock on her way down to the Pacific, and at Milaflores through two locks. Each of these three locks has, of course, a duplicate alongside, permitting, as at Gatun, the simultaneous passage of a companion vessel, or of one passing in the opposite direction. In case of repairs to one set of locks the parallel set would maintain the waterway.

The lift of the lower lock at Milaflores is variable, depending upon the level of the tidal water in the last reach of the Canal. The extreme range of the tide at $\mathrm{La}$ Boca, the Pacific entrance to the Canal, is 20 feet; that is to say, low water during "spring" tides is 10 feet below the average sea-level. 
66 THE PANAMA CANAL AND ITS MAKERS

During low tide on the Pacific side, therefore, the water in the Canal stands 95, instead of 85, feet above that sea. Hence the maximum lift of 32 feet already stated, for

$$
32 \times 3=96 .
$$

Beyond the Milaflores locks our vessel enters a reach of the Canal which is exposed to the ebb and flow of the tide and which will be confined within banks or levees as far as La Boca. In this respect the plan and the section are both, unfortunately, misleading. The La Boca lock and dam have been abandoned, and no Sosa lake will therefore come into existence, the lowest lock being, as I have said, at Milaflores. I have thought it better to reproduce the existing maps as they stand rather than to attempt a re-draught which would necessarily be imperfect. Our vessel, then, below Milaflores is in a tidal channel and will be subject to some tidal current. By designing this channel so as to avoid a bottle neck, and by giving it a width of 500 feet, the calculated current will, however, not exceed 1 foot per second. 


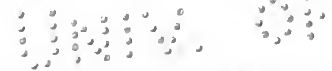

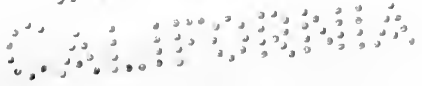

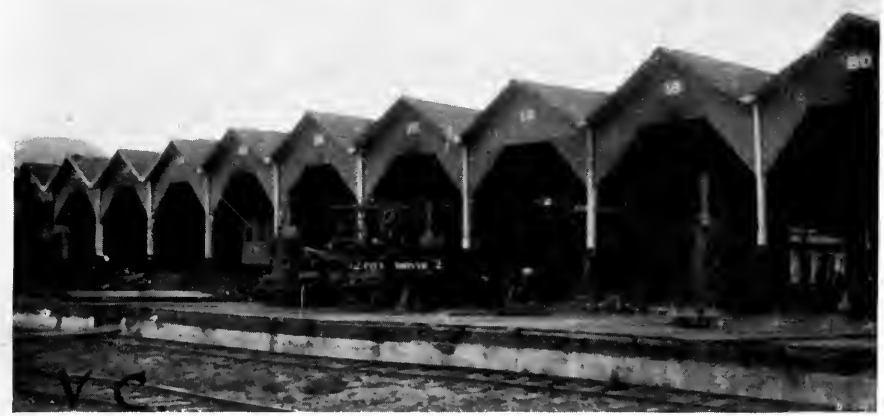

MACHINE SHOPS, GORGONA.

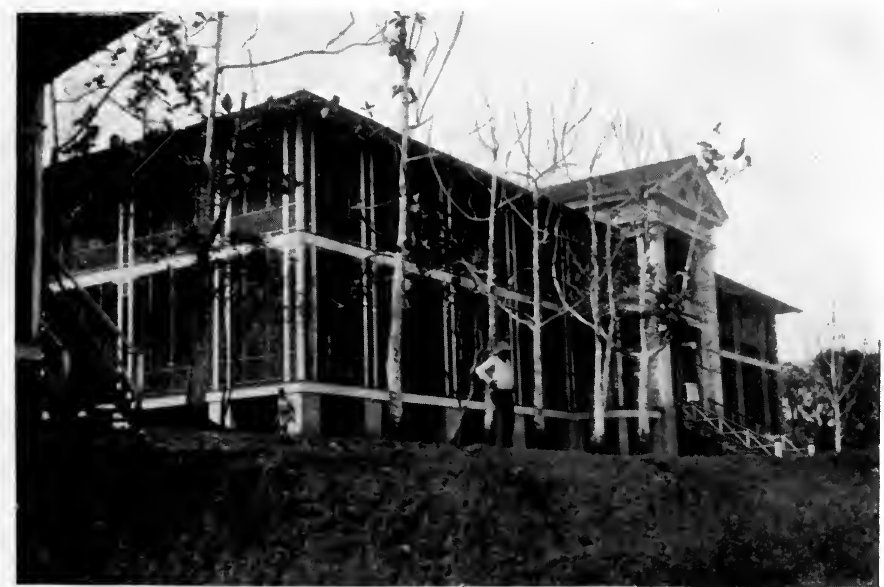

CLUB HOUSE FOR EMPLOYEES, GORGONA.

[To face page 66. 

The La Boca site for locks was found to be much too exposed to gun fire and other modes of attack from the sea, whereas the Milaflores site is not only distant about 5 miles from the shore, but is well sheltered both by hills near it and by the position of the hilly eminences of the shore line.

It will be seen from the map that the dredged sea channel by which our vessel will reach deep water on the Pacific passes to the west of the Isle of Naos instead of to the east, as was proposed in the earlier plans.

Returning now to the Gatun locks. The mitre sill of the top lock is 37 feet above mean sea-level, i.e., 48 feet below the surface of the lake, which is 85 feet above mean sea-level. But the bottom of the lake here is only about 5 feet above sea-level, the total depth of water immediately above the locks and dam being 80 feet. It follows that, in the extreme case of both gates of one of the top locks (as well as the roller gate) being wrecked, the level of the water 
68 THE PANAMA CANAL AND ITS MAKERS

in the lake can only fall to the level of +37 , which would leave a depth of 32 feet immediately above the dam. Ships of large draft could therefore lie there without being stranded. Moreover, the lake is so large that the outflow through the broken locks would only lower the level 2 feet per diem, so that more than three weeks would elapse before the water sank to the level of the mitre sill.

Again, the channel provided by the broken lock would be so small that in the Canal below the calculated current which would result from the outflow would have a velocity of only $3 \frac{1}{2}$ miles per hour.

Above the Pedro Miguel and Milaflores locks there is not the same surplus depth of water, so that vessels might be grounded if the locks were broken. Moreover, as there is no wide-spreading lake above Pedro Miguel, the outflow of water would generate a somewhat swift current above the lock, which might be a source of danger to ships.

This circumstance serves to enforce the apparent paradox that the great area of 
Lake Gatun is in several respects an element of safety, not, as the layman might suppose, of danger. The hydrostatic pressure upon the dam depends, of course, solely upon the depth of water, not upon the area of the lake, while the greater the contents of the reservoir the more nearly stagnant are its waters.

As there is to be no lock at La Boca, the dams shown there on the plan and profile will not have to be constructed, so that it is not necessary to deal with the questions to which they formerly gave rise.

In the vicinity of the locks at Pedro Miguel and Milaflores, however, dams have to be constructed to hold up the water. At both places the dams will be short, and will be founded upon hard rock, ${ }^{*}$ and in each case the head of water to be held up will only be about 40 feet, instead of 80 , as at Gatun. The construction of the dams at Pedro Miguel and Milaflores is not, therefore, regarded with anxiety.

* “Canal Zone Pilot,” pp. 316-317. 
70 THE PANAMA CANAL AND ITS MAKERS

The great Gatun dam remains the one important experiment in the whole scheme of the high-level Canal, and much attention is being devoted to the planning of this work. The alluvial foundation is a disadvantage shared by the Bohio site formerly chosen, and all other sites in the lower Chagres valley; so that, having decided upon the Panama route, and a high-level canal, there appears to be no alternative to the construction of a dam upon this kind of bottom. The details of the proposed structure, as elaborated in April, 1908, were as follows :-

The length of the great earthen dam at Gatun is 7,700 feet, its breadth no less than 2,060 feet. The weight of the dam per linear foot is more than 60 times the horizontal pressure of the water in the lake, so that the pressure could not move the whole mass; and the weight of the dam is spread over such a great width that it is not thought that the ground will sink beneath it. The form of the plan and section is shown on the map, and an idea of 
the topography may be obtained from the photographs, which I took in April, 1908. The south-eastern end of the dam abuts on the hill of hard, fine-grained, argillaceous sandstone in which the lock-site is being excavated.

The dam, according to these plans, is not to be merely superposed upon the surface, as originally proposed in 1905. Embedded in its earthy mass there is to be a puddled core, and a trench will be excavated to a level of 40 feet below the sea ( -40 feet) for the lower part of this core. Nor is this all that is to be done to check seepage beneath the earthen dam. From the bottom of the trench excavated for the puddled core, sheet piling, made of 4 -inch timbers, is to be driven down for another 40 feet, so that sheet piling and puddled core together will form an impervious barrier to -80 feet; that is to say, 80 feet below the surface-level of the sea, or about 85 feet below the lowest natural surface of the ground. The puddled core is carried up through the earthen dam to the level of +90 , that is to say, 5 feet 
72 THE PANAMA CANAL AND ITS MAKERS

above the level of the lake, which is to be 85 feet above sea. The crest of the dam will be +135 feet, i.e., 50 feet above the level of the lake; this excess of height being to provide top weight for increased stability of the whole structure, and also for the purpose of compacting the underlying material. The underwater slopes of the earthy materials have been reduced from the $1: 3$ of 1905 to $1: 5$. On the other hand, it has been decided that the width of 2,625 feet given in 1905 was in excess of utility, and that a reduction of between 500 and 600 feet can be made without loss of strength or efficiency.

About half way across the valley occurs a low hill, on which a house is shown in the photograph. This hill is on the crest-line of the dam, and is useful as giving support to the sides of the regulating channel which will be excavated in it. The material of the hill, however, is not the hard argillaceous sandstone of the lock site, but merely alluvial. The regulating works themselves will be built of concrete : a solid mass built 
up to +69 feet, and on this piers will be constructed 8 feet in thickness, between which will be the sluice-gates. By their means the level of the lake will be prevented from rising unduly in flood time.

The capability of the dam to maintain the waters of the lake at a sufficient level in the ary season depends upon their not finding a ready way either through the dam itself or below it. The construction of the dam is believed to guarantee its own practical impermeability. Not only is there a puddled core, but the mud, sand, and rocks of which the principal mass will be composed will be laid down in the manner best calculated to secure compactness. With regard to underground flow, there is an underlying bed of indurated clay which is regarded as sufficiently impervious, and wherever the puddled core and piling are imbedded in that clay it may, I think, be assumed with some confidence that the leakage will be unimportant. On referring to the section (map), however, it will be seen that there are in the valley two old river gorges, which to a depth 
74 THE PANAMA CANAL AND ITS MAKERS

of 200 and 260 feet are filled only with gravel, sand; sand, shells, and wood; clayey sand, and so forth. These gorges, measured on the section shown in the figure, have widths of about 1,200 and 500 feet respectively at the depth to which the sheet piling goes, and extend about 120 and 180 feet below. How much water may escape by these gorges it is difficult to say. This leads us to the next division of our subject.

On the Supply of Water Available for the Needs of the High-level Canal.

The construction of the Suez Canal was a work of excavation pure and simple. The construction of any kind of canal across the Isthmus of Panama involves another task, second only in importance to the primary work of excavation, viz., that of regulating the rivers.

In the case of a sea-level canal the problem would have been how to get rid of their waters, particularly in the rainy season. 
In the actual case of an 85-foot-level canal, the regulation of the rivers, particularly of the Chagres, presents two aspects, viz. :-

(1) In the wet season, disposing of the surplus waters.

(2) In the dry season, conserving water supplied by the rains so as to meet the waste caused (a) by locking, (b) by evaporation, (c) by percolation.

The arrangements for taming the torrents of the Chagres and its tributaries have already been described. They are, briefly, the construction of the Gatun dam and its spillway.

Turning to the other aspect of the problem, I have to answer the question, What is the guarantee that there will be sufficient water in the dry season?

Probably there is no problem of the Panama Canal which has received more prolonged and careful study than this. From the outset the French engineers commenced collecting data relating to the hydrology of the Isthmus, and when funds grew low, and the pro- 
posed level of the canal began to rise, the matter received ever-increasing attention. The Comite Technique of the New Panama Canal Company commenced in 1894 elaborate investigations to determine the catchment area, the amount of rainfall, and the discharge of rivers. Brigadier-General Henry L. Abbot (late Corps of Engineers, U.S.A.), whose investigations upon the Mississippi are known the world over, was a member of this Committee of the New Panama Company until the work was taken over by the Government of the United States, for whom he continued to act; and he was a member of the Board of Consulting Engineers, signing the minority report in favour of an 85-foot-level canal in January, 1906. A continuous study for seven years is an advantage enjoyed by few of the American engineers, and the book on "Problems of the Panama Canal "published by General Abbot in 1905 (new edition 1907) deals very fully and ably with the hydrology and meteorology of the Isthmus. The observations were continued under the direction of Don Ricardo 


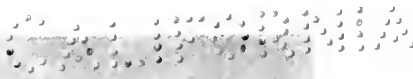

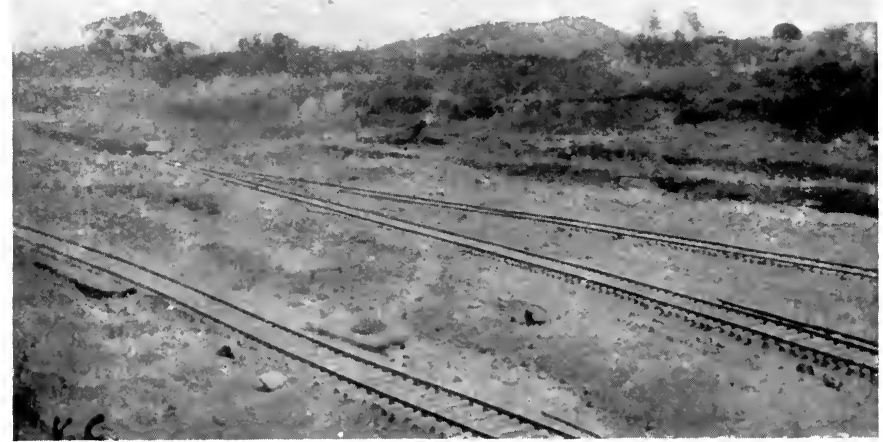

IN THE CUT, WIDTH 500 FEET.

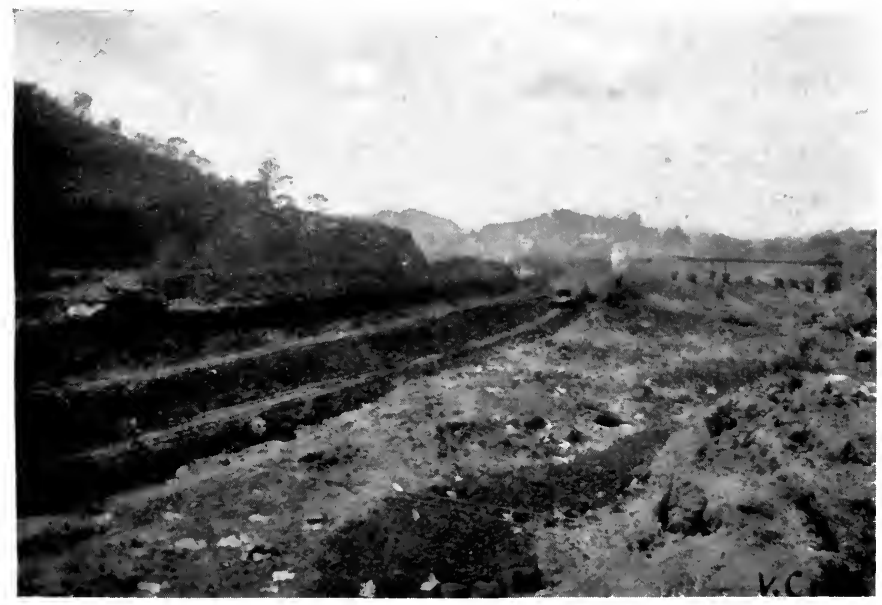

JOOKING SOUTH TOW.IRDS CLIERRA.

[To face fage ;6. 


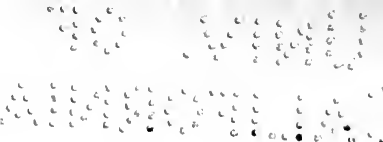


M. Arango, who has also a long experience on the Isthmus. I shall not attempt to summarise the mass of data upon which the authorities rely in their calculation that there is a sufficient water supply for the needs of the Canal during the dry season, contenting myself with showing, as above, that in this department of study, which more than all others connected with the Canal demands long experience, this requisite has in fact been secured. Yet whatever depends upon climate is liable to unexpected accidents, and personally $I$ regard as an important safeguard the fact that at Alhajuela, on the Chagres, 9 or 10 miles above Obispo, there is an excellent site for a dam, which would form a reservoir where some of the surplus water of the wet season could be stored, and supplied to the Canal as required. The details for such a dam were elaborated in connection with one of the earlier plans of the Canal, so that the necessary data would be immediately available in case its construction should become necessary in the future. 


\section{Harbours and Fortifications.}

There are no storms in the Bay of Panama, and but little additional protection from weather is needed there for shipping. The entrance to the Canal being at La Boca, a new city will grow up there. This will be the second westward migration of the terminal port, the present city of Panama lying between Old Panama and La Boca.

Colon is exposed to northers, and protection against the heavy sea which then rolls in will have to be provided. Whether this will be done by breakwaters or by forming an interior basin is not yet decided, and the cost of this part of the Canal works is therefore not yet known.

The Canal, as already stated, is to be fortified; but I made no inquiries as to the location or character of the proposed fortifications, a matter which I regarded as outside my province. The cost of fortifications is included in the provision made by Congress for the Canal. 
ON THE PRESENT CONDITION OF THE CULEBRA CUT, AND ON THE METHODS EMPLOYED FOR EXCAVATION AND DISPOSAL OF THE SPOIL 



\section{CHAPTER III}

ON THE PRESENT CONDITION OF THE CULEBRA CUT, AND ON THE METHODS EMPLOYED FOR EXCAVATION AND DISPOSAL OF THE SPOIL

REFERENCE once more to the plan and profile on the map will show at a glance the length and position of the rocky divide, the whole of which is termed the Culebra Cut, from the name of the town near the highest point. The proposed form and dimensions of this cut, throughout the 5 miles of the greatest height, is also shown (the section adopted at the commencement of 1906), and the stage reached in April, 1908, is shown by the photographs. The line drawn across the above section at a level of 120 feet above bottom (160 feet above sea), shows the general level of the bottom of the workings at Culebra itself at the time the photographs 
were taken. A narrow pilot cut, only, was then 20 feet lower.

All that part of the section below this line $(+160)$ remained to be excavated.

Most of the rock above this line has been removed, but not all, for the final width is not, of course, reached at any level until the central portion has been excavated below that level.

The level of the original rock line shown in this section was +275 , i.e., 235 above canal bottom, so that the photographs show excavation of 115 feet of rock. There was, however, soil above the hard basaltic rock, of varying thickness-removed to the slope 1:2 as shown on the section. The highest original surface of the soil on the centre line of the Canal (between Golden Hill and Silver Hill at Culebra) was + 312 feet, ${ }^{*}$ so that the photographs in which Golden Hill appears show a total excavation of 152 feet along the centre line. As this line passed along a saddle between the two hills, the original surface at the sides was considerably higher,

* The profile at end of volume shows the stage of excavation when the height here had been reduced to +210 . 


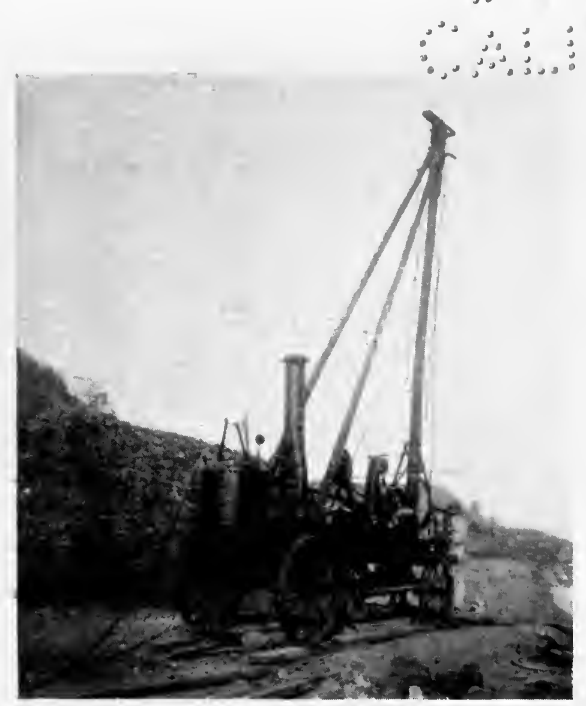

A ROCK DIILL.

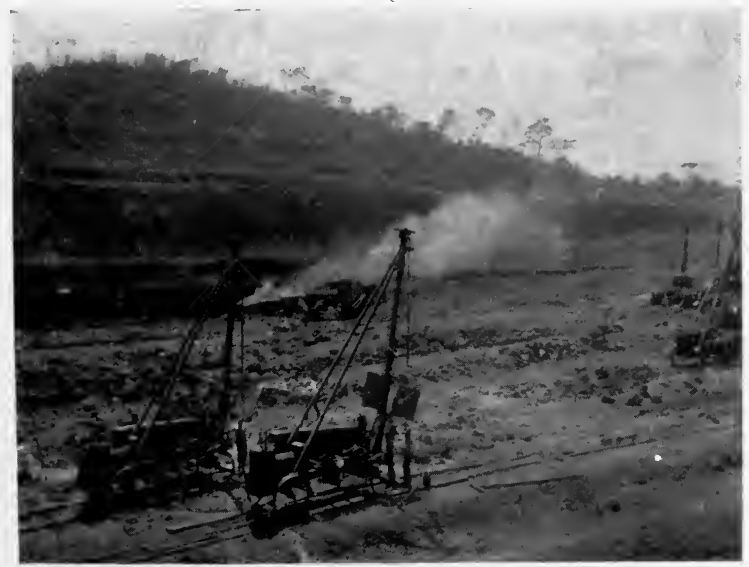

ROCK DRILIS IN THE CUT.

[To face pase 82. 
$\because 43$ 
so that the total height shown in the photographs from the bottom of the cut to the highest berm, or ledge, on Golden Hill is considerably more than 152 feet.

The bottom of the Canal will be 272 feet below the original saddle, and its depth below this berm, which is seen on the photograph, is considerably more. Thus will the gorge appear when the excavation is finished and before the water is allowed to flow in. When full, the surface of the water will be 227 feet below the original saddle, and the passenger on a vessel will gaze upon the scarped banks of a somewhat greater height than this.

For a tide-level canal, not only would the depth be 85 feet greater, but, as the slope could not be made steeper, the width of the whole cutting would be correspondingly increased.

With reference to the slope of the sides, it is important to note that it has not been found practicable to adhere always to the proposed section, which has to be made flatter, thus considerably increasing the amount of excavation required. The behaviour of living rock is not susceptible of the precise specifica- 
84 THE PANAMA CANAL AND ITS MAKERS

tion which can be applied to quarried stone on the one hand or loose gravel on the other. Mechanically it is complex, both on account of its structure and of the role which water plays in its economy. In the case of the Culebra rock, the volcanic dykes by which it is traversed have altered the nature of the rock in their vicinity, and the part played by water is considerable, owing to the wetness of the climate. Moreover, the rock does not remain wholly unchanged when exposed to air, but deteriorates by "weathering," a chemical and physical process which proceeds much faster in an equatorial climate than in the temperate zones. The climate, however, has a compensating action, in so far as the rapid growth of vegetation soon clothes and protects the scarped slopes, thus acting as a "revetment."

Alighting at Culebra station on the Panama Railway, and proceeding to the western side of the cut, one obtains the most impressive view of the Canal works, and this is the spot usually visited by travellers and tourists. 
I first stood there in January, 1907, and returned in April, 1908. The impressions obtained were very different on these two occasions. In January, 1907, after two and a half years of American occupation, what struck me most was the enormous mass of material which had been removed by the French companies, and the comparatively insignificant appearance of the American excavations, which could readily be distinguished from the older work, already coated with vegetation. It was then that I began to appreciate the heroic labours of the French engineers, whose achievements under circumstances of great difficulty are being daily more and more appreciated and praised by their successors. Turning to study the progress of work, I watched with delight the operations of the 100-ton steam shovels, which at a distance, when the human hands are not seen, appear endowed with volition, and remind the spectator of elephants at work. The cars were loaded with surprising celerity, and the dirt-train was hauled off to the distant dump by an old Belgian locomo- 
86 THE PANAMA CANAL AND ITS MAKERS

tive, part of the machinery taken over from the New Company. But then the hitch came -there were no cars to take the place of those already filled, and the steam shovel was idle. Looking round, I found that many other steam shovels and their crews were idle from the same cause, the machinery for transportation not having been provided in proper proportion to the machinery of excavation. That the time required for the completion of the rock-cut was limited by the possible rate of transportation of spoil, and not by that of excavation, had long been known, and the report of the Board of Consulting Engineers contains elaborate diagrams of space available for shovels and for tracks. It was apparent, therefore, that the organisation of the work was not yet perfected. In like manner, as far as I could judge during my first short visit, the West Indian labour was not yielding the best results, owing to white foremen and coloured labourers not being in perfect harmony.

While, however, the fighting force, so to speak, of the Isthmian army was obviously 
imperfect in many respects, great results had evidently been achieved by the auxiliary services. The Department of Sanitation had already made the Isthmus healthier than most equatorial countries, food and quarters were excellent, law and order were well maintained.

On the first day of my second and prolonged visit, April, 1908, fifteen months later, I went at once to the same spot on the Culebra Cut opposite to Golden Hill and again surveyed the scene of operations. The change was enormous. The gorge below me was greatly enlarged, the shape of the hills altered, the face of the landscape changed. As I gazed into the deep trench below, the thought flashed across my mind, "If my life be spared a few years longer, I will sail through this on a ship."

The reason of the great change was readily apparent: organisation had now been perfected. In the first place, the whole width of the cut was laid down in railway tracks, tier above tier at the different levels, so that the view was like the approach to the metropolitan terminus of one of the world's 
great railways. Up and down these tracks there came and went without ceasing the spoil-trains, now composed of larger trucks than formerly, with new and ingenious devices for rapid unloading. The number of steam shovels visible was much larger than in 1906, yet they were kept constantly busy, and all the time the drilling machines were at work boring holes for charges of dynamite, and gangs of men were completing the preparations for explosions in other holes already made.* Yet if the eyes were raised for a moment from the busy scene below, they rested on a silent wilderness of tropical forest, stretching unbroken to the horizon. I stayed until, at the approach of sunset, the work of the shovels ceased, and hundreds of men swarmed out of the Cut, and sought their quarters and the evening meal. But all was not over for the day, for now, when the Cut was cleared, the shotfiring began. At intervals there occurred a deafening explosion, the earth trembled as * During 1908 no less than one million dynamite charges were exploded. 
in a considerable, but preternaturally short, earthquake, and masses of rock rolled down the slopes, disintegrated and ready for the shovel-man when he should arrive next morning. I paid many visits to the Cut, between Empire and Pedro Miguel, but oftenest at Culebra itself. The sight never palls, and is one of the wonders of the world. The Pyramids are another wonder of the world which in common with many thousands in all ages I have thought it worth going to see-but to go to Culebra is as if one were privileged to watch the building of the Pyramids. Yet how few go to the Isthmus on purpose to see these things, and, mirabile dictu, how few Americans! How is it that this people, so enthusiastic in all that relates to national achievement and addicted to foreign travel, does not include the Isthmus among its many recognised places of pilgrimage? Of the Americans whom I met on the Zone there was scarcely one who had come voluntarily for pleasure. The hotel accommodation, it is true, is limited, but it is more than sufficient for 
90 THE PANAMA CANAL AND ITS MAKERS

present needs, and is good, as hotels in the tropics are reckoned. Moreover, Panama is now one of the healthiest places in the Equatorial Zone. English tourists going out to the West Indies by the Royal Mail are generally able to cross the Isthmus and see something of the work while their ship is unloading at Colon; but I would venture to suggest, to such of these as care to follow the world's progress, that they should make arrangements beforehand to step off at Colon, cross to Panama, put up there, visit thence the Canal works at various points, and proceed by their next ship. The West Indian tourist season coincides with the dry season on the Isthmus. At Panama the mosquito is almost an extinct animal, and though the heat there is sometimes trying, a run up to Culebra brings one to a dry and bracing atmosphere where a fresh breeze is almost always blowing.

The steam shovel is the principal agent of excavation. It scoops out loose soil directly, but the basaltic rock has to be broken up first by blasting. One shovel 
will load 1,200 cubic yards of such materials upon the cars within the working day of 8 hours, an amount equal to 600 two-horse loads.

For accelerating transportation railway trucks provided with flaps are used, which make of the whole train a single platform. At the rear of the train is a plough which can be drawn by a wire rope attached to a drum carried on a special car in the fore part of the train. When the train arrives at the dump the drum is started, and the plough, advancing, clears the 320 cubic yards of earth and rock from the 16 cars in 7 minutes. This is the Lidgerwood Unloader.

Another important piece of machinery is the track-shifter, which picks up and relays the railway lines of the ever-shifting spoiltracks. This remarkably successful contrivance was invented by an employee on the Isthmus, and is moreover manufactured there in the great workshops at Gorgona.

From Bas Obispo to Pedro Miguel, which constitutes the Cut, is a distance of about 9 miles, and excavation is so planned that a summit is maintained at Lirio, near Culebra, 
about half-way between these two points. On the north slope are* 21 steam shovels, loading cars on 14 tracks. These, when loaded, are hauled down-grade to the northern dumps at Tavernilla and elsewhere, or to the site of the Gatun dam, which is also a dump. Nearly 4,000 cubic yards of rock are carried to the dam daily, a distance of about 24 miles. The return up-grade is made with empty cars. On the southern slope about the same number of steam shovels are at work, the spoil being taken to the southern dumping grounds on the Pacific side, including the trestle dump for the breakwater to Naos Island. The spoil-trains follow one another at intervals of about three minutes, and if, from any cause, delay occur, the steam shovels, and indeed the whole process of excavation, is brought to a standstill. Any cause of delay is therefore reported at once by telephone to the Superintendent of Transportation at Empire, and all energies are at once directed to clearing the way. On the Isthmus everything gives way to the spoil* This is for July, 1908. 
Masom 
train, as in a city to the fire-engine. An excellent lesson both in the complexity and urgency of the transportation is afforded by a run through the Cut on a motor trolley in company with the Superintendent of the Department of Excavation. Constantly shunted from one track to another, and occasionally having to retreat, much ingenuity is required to thread a way among the spoiltrains, but even the almost invaluable time of the Superintendent himself is sacrificed rather than any delay should occur to the " dirt" train, as it is usually called. It is this dirt which stands between the American nation and the realisation of their long cherished scheme, and nowhere is the classical definition of dirt as "matter in the wrong place" so appropriate as on the Isthmus.

Let us now see how much matter has been removed, and how much dirt remains which has yet to be removed. I will give first the totals of what has been got out in both dry and wet way, both in the Canal prism itself and for auxiliary works. 


\section{THE PANAMA CANAL AND ITS MAKERS}

Total Excavations in Connection with the

$$
\text { Panama Canal.* }
$$

By the French Companies about ... $\quad 81,548,000$ By the American Isthmian Canal Commission up to the end of June, 1908

$$
\text { ... } \frac{40,923,533}{122,471,533}
$$

Much of the work of the French Companies, however, consisted in dredging out sea-level channels at both ends of the Canal, whereas the principal American work has been rock-excavation in the Culebra Cutor the Cut, as it might equally well be called. The figures relating to the Cut are :-

Excapation between Bas Obispo and Pedro Miguel, i.e., "The Culebra Cut," $9 \frac{1}{2}$ Miles.

By the French Companies Cubic Yards.

By the American Commission to end of June, 1908

... $20,125,185$

Total excavated in the Cut $22,600,000$

Remaining to be excavated

$$
\text { ... } \overline{42,725,185}
$$

... $37,973,063$

$80,698,248$

* Canal Record, July 8, 1908. 
so that at the end of last June the Cut was half cut through, one quarter having been done by the French Companies and one quarter by the American Commission.*

This statement by itself, however, would give a very inadequate idea of the rate at which the excavation is now proceeding, for of the total taken out by the Commission since 1904, 11,000,000 cubic yards were due to the work of the 12 months prior to June last. It will be seen from what has gone before that the rate of progress is now even greater than in the year June, 1907-May, 1908, for the daily output from the Cut for July, 1908 (55,427 cubic yards), works out at 1,441,102 cubic yards, allowing 26 working days of that month, which, moreover, is a wet month, when work is much retarded.

On the Date of Completion of the Canal. Colonel Goethals, Chief of the Commission,

* The total excavation for the prism of a sea-level canal was calculated by the Board of Consulting Engineers at 231,026,477 cubic yards. 
when examined early in 1908 at Washington, declined to bind himself to a date for completion, or to an estimate of cost; nevertheless, it is not difficult to calculate the date of completion from the actual rate of progress on the assumption that all goes well. The year 1915 is thus arrived at by the authorities for the calculated, though not promised, completion. This is based primarily upon the rate of excavation possible under the restrictions imposed by the narrow gorge along which the spoil has to be transported. It has been also calculated that the constructive works, the locks and dams, would require about the same time as, but not longer than, the excavations. This just balance between the time required for the two elements, excavation and building, was one of the arguments employed in favour of the 85-foot-level canal, as securing "the utmost practicable speed of construction"* which could be obtained in a canal "afford-

* See address by President Roosevelt to Board of Consulting Engineers, September 11, 1905. Report of the Board, p. 12. 
$\therefore$ a 
ing convenient passage for vessels of the largest tonnage."

One of the most impressive features on the Isthmus at the present time is the great workshop at Gorgona, where repairs of all kinds are done, and large machines such as the track-shifter are actually built. As I passed from machine shop to boiler shop, smith shop, car shop, pattern shop, and so on, I felt myself back among the circumstances of one of the great manufacturing towns, and forgot for the time my actual surroundings. It was with a feeling akin to surprise that, on quitting the foundry, I found myself on the fringe of the tropical forest, now darkening with the shadows of the swift-descending sun. I may here note by the way that the furnaces of the foundry produced considerable relief from the effects of the tropical heat, which that day was somewhat oppressive.

Relaying the Panama Railway.

Reference to the map at the end of the 
volume will show how considerable is the task of reconstructing the Panama Railroad-what embankments have to be formed, circuits made, and (near Milaflores) a tunnel bored. The track, too, is being doubled, and the rolling stock has been greatly improved. The passenger cars are both comfortable and relatively cool, and the double journey from Pacific to Atlantic Ocean and back again can be pleasantly performed between luncheon and dinner. Much of the verdant forest land on which I have gazed with so much delight from the windows of the cars will soon cease to be land at all. It will be drowned beneath the waters of Lake Gatun; virgin forest, cultivated patch, squatter's hut, villages, and even small towns will disappear, their sites submerged by water, and presently to be covered by the silt of rivers. 


\section{THE MEN ON THE ISTHMUS}





\section{CHAPTER IV}

THE MEN ON THE ISTHMUS

West Indian Labour.

$7 \mathrm{HE}$ success of sanitation, and the modern

1 facilities for storage of food, have greatly simplified the task of obtaining an adequate supply of navvies for the pick and spade work. In the United States the American-born, particularly the majority who are of Anglo-Saxon stock, now form an aristocracy of labour, and for the last fifteen years or so have performed but little of the pick and spade, or ordinary navvy's, work. In the Southern States the unskilled labour is mainly performed by the American negro. Elsewhere the pick and spade work is done by new immigrants, some of whom settle, 
and some go home with their savings. They are largely from Southern and Central Europe, many being Italians, and in the extreme West there are Japanese also.

The Commission, however, did not recruit in the United States, in order not to disturb the labour market there, but sought elsewhere for the supply of unskilled labour.

At first they relied almost entirely upon the West Indian negro, who formed the majority of the navvies employed under the French Companies. The Commission, however, were profoundly dissatisfied with the result. In December, 1906, they reported that-

"Another year's experience with negro labourers from near-by tropical islands and countries has convinced the Commission of the impossibility of doing satisfactory work with them. Not only do they seem to be disqualified by lack of actual vitality, but their disposition to labour seems to be as frail as their bodily strength."

Nevertheless, they are still employed in undiminished numbers on the Isthmus, and 

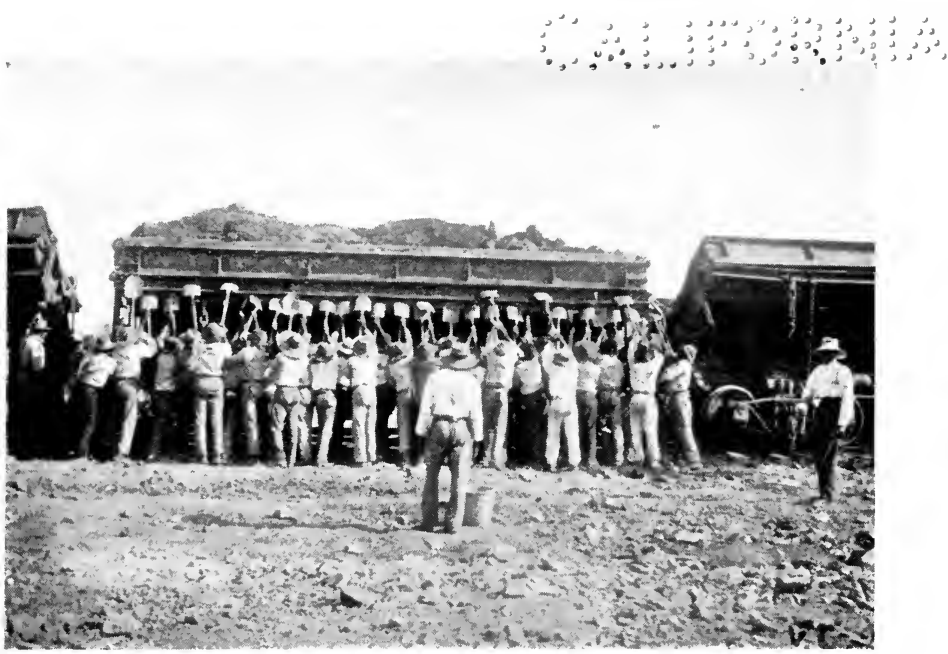

WEST INDIAN LABOURERS AT GATUN.

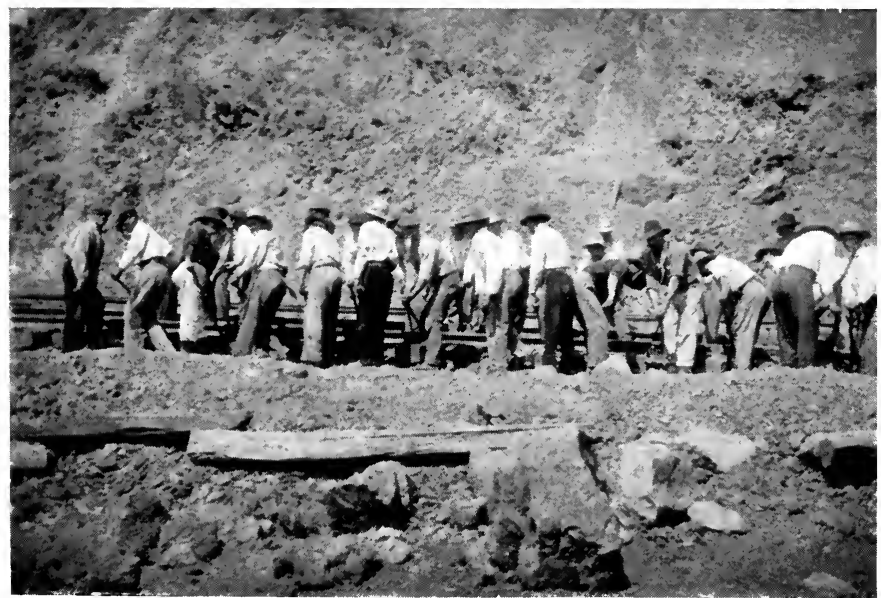

SPAXISH IABOLIERS AT CULEBRA.

[To face page 102: 


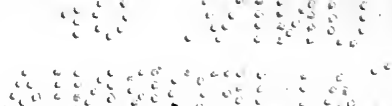


the tone of the authorities towards them has changed. This change is noticeable both in the official publications and also in the conversation of the foremen immediately in charge. With regard to the latter, I found a great difference of tone between January, 1907, and April, 1908.

The improved relations with the West Indians is due to two causes, relating to the alleged lack of vitality and of industry respectively. The lack of strength was found to be due largely to improper diet, and most of the West Indians are now provided with proper cooked meals, as is done in the case of American and European employees. In order to ensure their profiting by this provision, however, the charge for meals in the case of West Indians is deducted from wages. The result of supplying a nourishing diet has been a marked increase in working strength as shown by output.

In respect of disposition to labour there has also been an improvement. This is shown both by the absence of animadversion in later official reports, and also by the 
104 THE PANAMA CANAL AND ITS MAKERS

changed tone of the foremen and other Americans in immediate control of the West Indians, when questioned on the subject. In January, 1907, I heard little but disparagement, while in April, 1908, a much more favourable account was given. To one who has seen something of both the United States and of the West Indies, the reason for the improved state of affairs was easily understood, viz., the American foremen and others in charge had begun to understand the type of men with whom they were dealing. Accustomed to the character of the American negro, and to the conventions which regulate intercourse with the coloured man in the United States, they did not at first recognise that the West Indian was a distinct type, and accustomed, at any rate in the British Colonies, to very different social relations towards the white man. The handling of a gang of negroes from the tropics is an art which has had to be learnt.

The Barbadians are reported to be, generally speaking, the best of the West Indian workmen, except the men from some of the 
country districts of Jamaica, who are their equals. Although the climate and products of the Isthmus are so similar to those of their own islands, comparatively few of these employees settle there, but return to the homes they love so well. It cannot but be gratifying to an Englishman to find that those who come from the British islands are proud of their citizenship and pleased to greet him as a fellow-subject.

There are about ninety negro policemen on the Zone, most of whom were originally trained by English officers in the Jamaica Constabulary. They are highly spoken of by the Chief of Police, who finds that they know both when to arrest and when not to arrest. They are also of much service to the new arrivals of their own colour, who refer to them for all information.

The ordinary West Indian labourer receives 10 cents gold (about 5d.) per hour and free quarters. Deducting the 30 cents per diem charged for meals, he receives 50 cents (2s. 1d.) for an 8-hour day, besides food and lodging. 
The total number actually at work on the Isthmus has been-

$$
\text { June 30, } 1907 .
$$

On the Canal Works

On the Panama Railroad

$$
\begin{array}{ccc}
\ldots & \ldots & 14,606 \\
\ldots & \ldots & 4,979 \\
\text { Total } & \ldots & 19,585
\end{array}
$$

and on June 30,1908 , the number on the Canal Works alone was 16,078.

The total number on the roll is, of course, considerably more than 20,000, as there are necessarily absentees every day owing to sickness, accident, or other cause.

\section{European Labour on the Isthmus.}

In 1906 the number of European labourers on the Isthmus was insignificant, and the Commission, at that time profoundly dissatisfied with the West Indians, issued invitations for proposals to furnish 2,500 Chinese labourers, with the privilege of increasing the number to 15,000.* Nothing

* Report of the Isthmian Canal Commission, 1906, p. 14. 


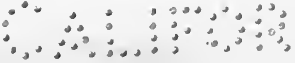

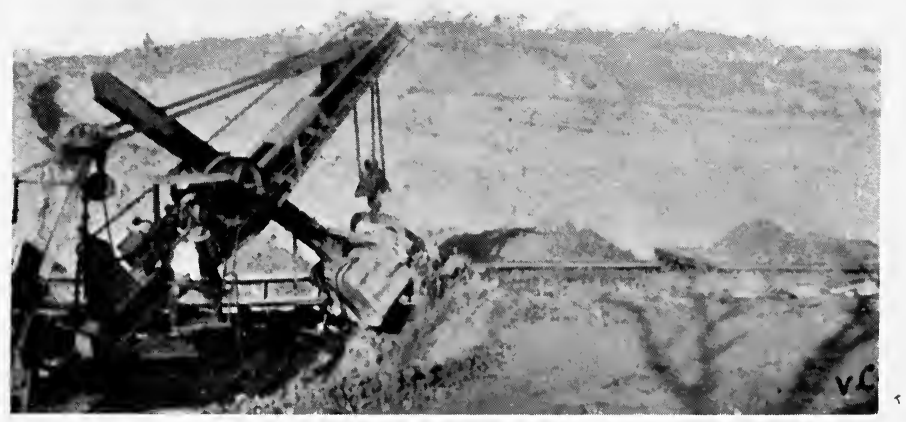

STE.II SHOVEL EXCAVATING SOIL AT CULEBRA.

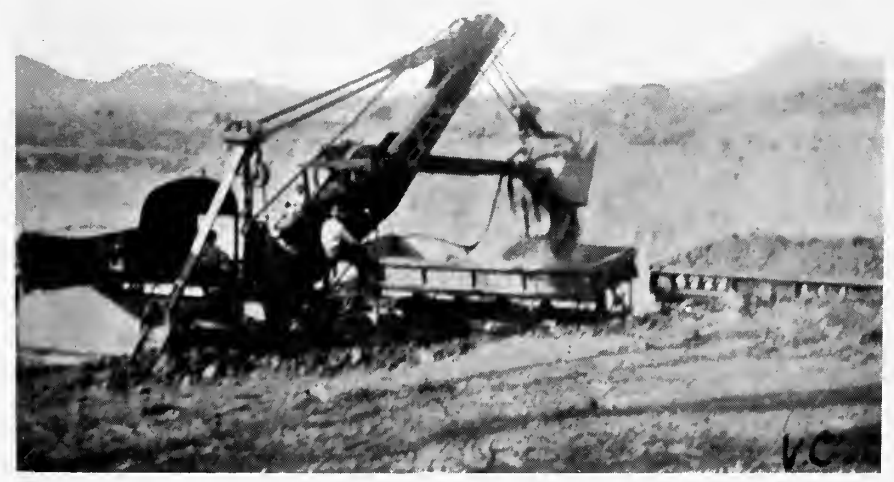

STEAI SHOVEL UNLOADING INTO DIRT CAR.

[To face pase so6. 


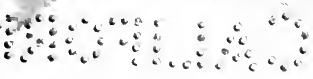

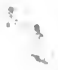


came of this scheme, however, while, on the other hand, the already improved, and still improving, conditions on the Isthmus enabled the Commission to obtain a largely increased supply of European labour. While the supply of West Indians was maintained constant, or only slowly increased, the additional force required was therefore obtained from Europe. The following figures show this :-

\section{European Labourers actually at Work on}

$\begin{array}{cccccr}\text { June } 30,1906 & \ldots & \ldots & \ldots & \ldots & 500 \\ \text { June } 30,1907 & \ldots & \ldots & \ldots & \ldots & 4,317 \\ \text { June } 30,1908 & \ldots & \ldots & \ldots & \ldots & 4,913\end{array}$

A few Russian and Baltic folk came, but appeared unable to stand the work, and the few French who arrived did not take to pick and spade. The majority were from Greece, Italy, and Spain, each of these countries sending at first about the same number. The Greeks proved to be physically inferior to the Italians and Spaniards, and their number in April, 1908, was only about 300 . 
The Italians, physically excellent, and standing the climate well, were found somewhat intractable. A large proportion were migrant labourers, who had become somewhat prone to collective action when dissatisfied, and their numbers in April, 1908, had been reduced to 500 or 600 .

The Spaniards, mainly Galicians and Castilians, were found to be quite equal to the Italians in physique and health, and to give far less trouble, a fact which is attributed partly to the circumstance that most of them came directly from their villages. They are reported to be sober, patient, civil, and quick to learn. The number employed in April, 1908, was about 5,000, so that the Spaniards constituted about five-sixths of the European force, which numbered in all slightly over 6,000 . The figures given above for those at work on certain days are considerably less, there being always a number absent from one cause or another.

That the Spaniard is not oppressed by the tropical heat was apparent to me when watching gangs at work near mid-day at about the 
hottest time of year, viz., the last weeks of the dry season, towards the end of April. Clothed in European kit, wearing velveteen trousers and with only a. cap for headcovering, these men showed no signs of distress, or even discomfort. They showed, in fact, less sign of being heated than Americans of apparently British or other Northern descent engaged upon less laborious work.

The ordinary European labourer, in addition to free quarters, receives 20 cents gold per hour, or $\$ 1.60$ per 8-hour day; more when working overtime. $\mathrm{He}$ is charged 40 cents per diem for his three meals, served in the European mess, which leaves $\$ 1 \cdot 20$ as a minimum net wage per diem, or a little less than 30s. per week; but many earn more, and it should not be difficult under these conditions for a labourer to save $£ 5$ a month. I was informed of one instance of a Spanish labourer saving $£ 10^{\circ}$ per month, but such virtue must be rare.

The Spaniard shows no sign of settling upon the Zone. Sometimes he goes on to 
110 THE PANAMA CANAL AND ITS MAKERS

railway work in Brazil ; more often he returns home with his savings.

\section{Skilled Labour on the Isthmus.}

The skilled labour on the Isthmus has from the outset been mainly done by white Americans, but there are still on the "Gold Roll," as it is termed, some Europeans. New rules reducing the maximum length of leave have, however, made these posts less attractive to those whose homes are at a greater distance, and by an order of February 8, 1908, all future appointments on the Gold Roll shall be American citizens, if the special services required can be obtained in the United States; and in the event of any reduction of force, preference shall be given to American citizens.

The duties being various, the pay necessarily differs, but, taking free quarters into account, is higher than in the United States, as is of course necessary in a distant and tropical land. Since the industrial difficulties of 1907-8 there has been considerable competition for these billets. An 8-hour day 
is established by law for employees on the Gold Roll, the quarters are excellent, and the three meals a day provided at a fixed charge are up to the standard of a good hotel. Indeed, the opportunity to share these meals, supplied in large airy rooms, screened by gauze but open to the breeze, made my task on the Isthmus much lighter. From almost any part of the Canal I could reach one of the Commission "hotels" for meal-time, and for 50 cents (2s. 1d.) obtain better food than I have generally been able to get in the tropics at a much higher price. I took pleasure also in my company, for, if I may be permitted to say so, the skilled mechanic of the United States has always seemed to me a most attractive representative of his nation; and here particularly so, where one is in touch with his work. Moreover, each man's job on the Isthmus is part of a vast undertaking, the progress of which he can watch, which fires his'enthusiasm, and makes him feel that he has a reward beyond his wage in the privilege of participating in national achievement. 
112 THE PANAMA CANAL AND ITS MAKERS

I should like in this place to add a word of tribute to the great courtesy and kindness which they show towards ladies, a circumstance which did much to render pleasant the excursions which my wife took on the Isthmus, sometimes in my company and sometimes alone.

The number of Americans on the Gold Roll in January, 1908, was about 6,000, the total number of employees on the rolls of the Commission and of the Panama Railroad being then approximately 43,000. The total number of employees actually at work on January 29, 1908, was

On the Canal works $\quad \ldots \quad \ldots \quad \ldots \quad 25,367$

On the Panama Railroad $\quad \ldots \quad \ldots \quad 6,557$

Total $\quad \ldots \overline{31,924}$

The Responsible Officials and the Scheme of their Organisation.

The responsibility for Canal construction under the conditions laid down by Acts of Congress is vested in the President of the 

United States, within the limits of the money which has so far been voted. The President appointed a Commission in 1905 to carry out the work. The first chief engineer appointed was Mr. John F. Wallace, who arrived on the Zone June 28, 1904, accompanied by Colonel Gorgas, U.S.A., head of the Sanitation Department. Mr. Wallace was in favour of a tide-level canal. In April, 1905, the President appointed a second Commission in place of the first, with a changed personnel,* but Mr. Wallace was retained as chief engineer, and, moreover, became a member of the second Commission.

$\mathrm{He}$, however, resigned, June 26, 1905, and his place was taken by Mr. John F. Stephens, who arrived on the Zone July 27th. At this time there was panic throughout the Isthmus $\dagger$ owing to the prevalent sickness, and resignations were so numerous that it

* Colonel Gorgas, head of the Department of Sanitation, has remained, however, through all changes. See post, Chapter V.

+ See Report of the Governor of the Canal Zone, 
114 THE PANAMA CANAL AND ITS MAKERS

was difficult to carry on work at all, and engineering operations were partly suspended for a time. When the sanitary conditions improved, however, work was resumed with vigour. This second Commission proposed that the work should be put out to contract, and bids were invited. It was under this Commission that the 85-foot-level canal became law. Mr. Stephens was in favour of this form. He resigned early in 1907, his resignation taking effect on April 1st, and at the same time the President for the second time reorganised the Commission.

The third Commission, appointed April 1, 1907, which is that under which the work was being carried on at the time of my second visit, differs from its predecessors in that its members are resident on the Zone. Thus the members of the Commission are the actual executive, the chairman of the Commission being himself chief engineer.

1905 , p. 30, and "Sanitation in the Canal Zone," by W. C. Gorgas, M.B., Colonel, Journ. Am. Med. Assoc., July 6,1907 , vol. xlix. 
The other important difference between the present and the former organisations is the fact that almost all the important departments are now under officers of the United States Army, and in one instance of the Navy. The chairman and chief engineer, Lieutenant-Colonel George W. Goethals, of the Corps of Engineers, had previous experience of the Isthmus, having been engaged upon work connected with fortification. With respect to the other officers of engineers, the significance of the appointments lies not in their being military men, but in their being permanent Government servants. The Government of the United States, unlike that of his Britannic Majesty, does not possess a large Civil Service whose members remain in the public employment through all changes of political parties. In the absence of any considerable body corresponding, for instance, to our Indian Civil Service, the Government of the United States frequently relies upon the Corps of Engineers for the supervision of great public works.

At the time of my second visit the scheme 
116 THE PANAMA CANAL AND ITS MAKERS

of organisation was as shown in the following table :-

General Organisation of Departments.

\begin{tabular}{|c|c|c|}
\hline & Men & \\
\hline Excavation and Dredging & $\begin{array}{r}12,359 \\
9,340\end{array}$ & Major D. D. Gaillard \\
\hline Machinery and Buildings * & $\begin{array}{l}9,540 \\
2,164\end{array}$ & H.H. Rouseau, U.S.N. \\
\hline $\begin{array}{c}\text { Labour, Subsistence, and } \\
\text { Quarters }\end{array}$ & 2,048 & $\left\{\begin{array}{c}\text { Jackson Smith (re- } \\
\text { signed) }\end{array}\right.$ \\
\hline Material and Supplies .... & 1,220 & W. G. Tubby \\
\hline Sanitation... $\quad \ldots \quad \ldots$ & 2,449 & Colonel W. C. Gorgas \\
\hline Civil Administration & 451 & J. C. S. Blackburn \\
\hline Panama Railroad & 6,619 & W. G. Bierd \\
\hline
\end{tabular}

* Now merged in other departments.

Technically the Panama Railroad is not a department, but practically the construction of the Canal and the reconstruction of the Railroad are worked as parts of a single scheme.

In addition to the above are some smaller divisions, reporting directly to the Chairman, such as that of Accounts. The office of the Purchasing Officer is situate in Washington, practically all the supplies being obtained in the United States. This officer also reports to the Chairman resident on the Zone.

The numbers given above are subject to 


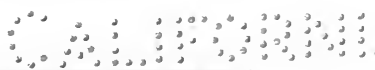

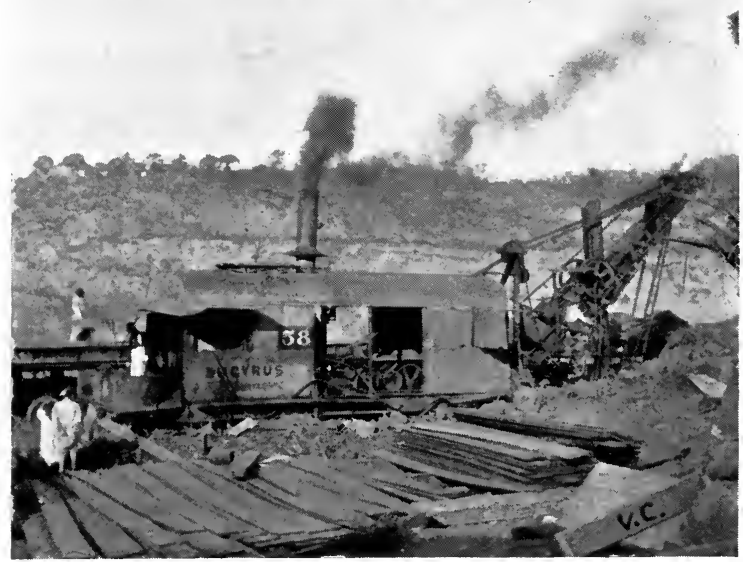

STEAM SHOVEL AT CULEBRA.

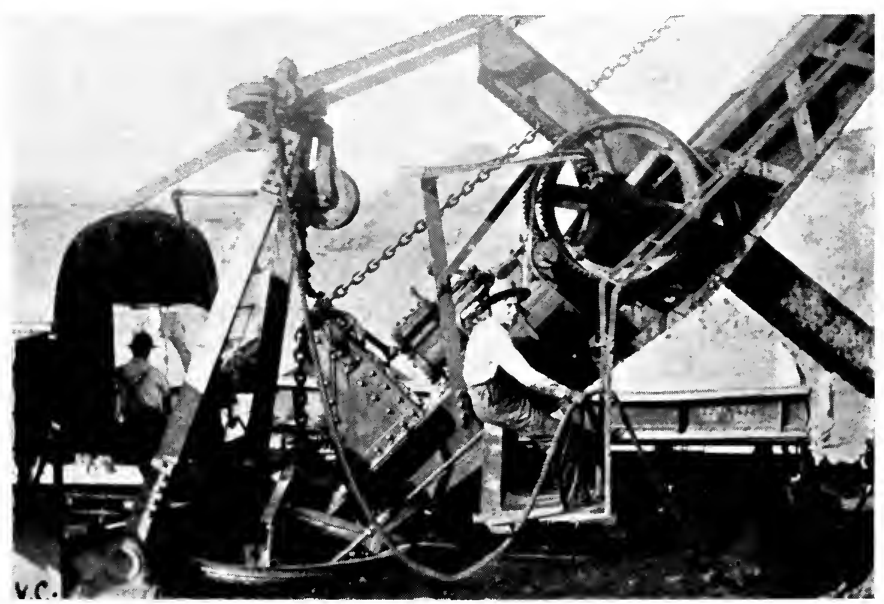

SHOVEL-MIEN AT CULEBRA.

[To face page 116. 
andran a 
continual fluctuation, and are quoted more for the purpose of showing the general proportions of the different parts of the undertaking than to give an exact total of the force employed.

Some account has already been given of the activities of the men employed on excavation, on locks and dams, and on the railway. Those entered under the Department of Machinery and Buildings are charged not only with this work in the Zone, but also with the paving and other improvements in the cities of Colon and Panama. The Department of Sanitation also undertakes the hygiene of these two cities, no small part of its responsibilities. The Republic of Panama provides the cities with police, who are Panamanians. The police force of the Isthmian Canal Commission (Department of Civil Administration) numbers 200, of whom 88 are the West Indians already mentioned and the remainder white Americans. The force is numerically small, but the power to deport all undesirable persons is of great assistance. Moreover, as the Zone is practically inaccessible except from the 
118 THE PANAMA CANAL AND ITS MAKERS ports of Colon and Panama, a fairly complete watch can be kept on all entries. After making due allowance for all these advantages, however, one cannot but be impressed, not only by the order, but by the respectability of the Isthmus, which is singularly free from anything unseemly.

A scattered force of 200 would be insufficient to deal with tumult among so large a population of men, but there is maintained at Obispo, a central point, a force of about 350 United States Marines.

The work of the Department of Sanitation is of such primary interest and importance, especially to geographers, that I deal with it separately in the next chapter. 


\section{HEALTH ON THE ISTHMUS AND THE FUTURE OF THE WHITE RACE IN THE TROPICS}





\section{CHAPTER V}

HEALTH ON THE ISTHMUS AND THE FUTURE OF THE WHITE RACE IN THE TROPICS

\section{Yellow Fever.}

$\Gamma^{H E}$ cities of Colon and Panama have 1 never been particularly unhealthy to the Panamanian born, whether white or coloured, or to the West Indian stranger.

This population has merely been subject to the malaria common to equatorial towns, especially when in the neighbourhood of swamps, and to the evils which attend imperfect sanitation in a hot climate.

The intervening country is very malarious in the low-lying parts, less so on the hilly divide, differing in no way from other similar localities in the same latitude. 
122 THE PANAMA CANAL AND ITS MAKERS

The reputation of the Isthmus of Panama as a death-trap is due to the sickness which (previous to 1906) has always been prevalent among white strangers, and most other visitors, and particularly to the high percentage of death from yellow fever. To this short, sharp, and most deadly disease the native-born is immune; hence the affairs of the city of Panama have gone on well enough for centuries, as far as the residents are concerned, except that travellers by the Isthmian route tarried no longer than they could help. Whenever large numbers of strangers have congregated on the Isthmus, as during the Californian gold-rush, the construction of the railway, and the Canal construction of the French Companies, there has been an epidemic of yellow fever among them, and a very large proportion of cases have terminated fatally.

The immunity which the West Indian negro enjoys from this disease gave him a superiority over other labourers on the Isthmus which, since the extinction of the disease, is no longer his. 


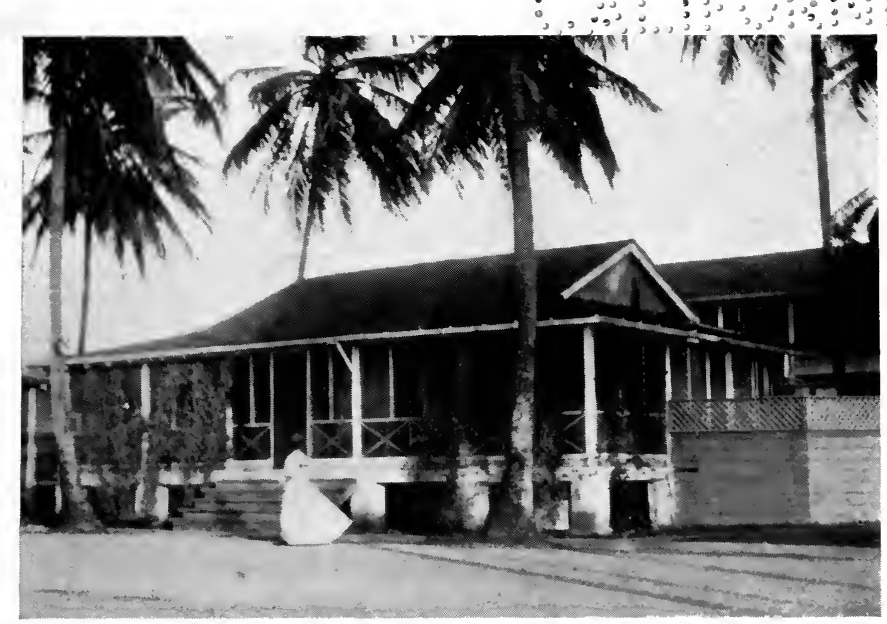

SCREENED BUNGALOW, CHRISTOBAL, COLON.

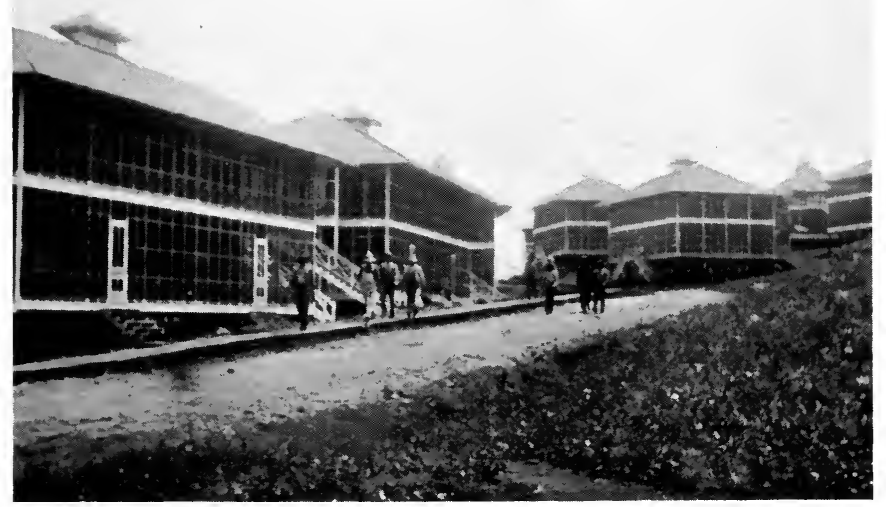

SCREENED QUARTERS OF EMPIOYEES, CULERRA.

[To face fage 122. 

During the American occupation of Havana, after the American-Spanish War, yellow fever broke out among the strangers, and the mere cleaning up of the city, though carried out with military thoroughness, had no effect in checking the disease. A medical board was sent to study the matter. This was in 1900, four years after Major Ronald Ross, of the Indian Medical Service, had discovered the cause of malaria. Ross had proved that the cause of malaria in man was the presence in his blood of an organism introduced by the attack of the anopheles gnat (or mosquito), and that the species was only poisonous to man if it had itself become infected with the germ of this organism in biting man suffering from malaria. Thus man and anopheles act alternately as hosts to the organism, which apparently requires their co-operation for the continuance of its species.

Gnats, or mosquitoes, as they are indifferently termed, being thus under more than suspicion as an immediate cause of tropical fevers, the medical board turned their attention 
to them, and Mr. Reed, a member of the board, tracked the yellow fever to another gnat, the stegomyia, and, aided by the heroic devotion of his assistants, proved beyond shadow of doubt that this disease is due to the activity of another minute organism, which lives a double life in man and stegomyia. Mere contact with the clothing, \&c., of yellow-fever patients was proved to be no source of infection.

The stegomyia lives three months. It becomes dangerous only by imbibing the organism through attacking man during the first three days of yellow fever, and, even then, twelve days elapse before its bite is infectious. Six days after a man has been bitten by an infectious stegomyia he develops yellow fever, and for the next three days (as has been already said) he is infectious to the stegomyia.

During the American occupation of Cuba attempts were made to obtain immunity from yellow fever, but it was found impossible to regulate the disease when voluntarily communicated by the bite of the mosquito, and 
at present immunity is only enjoyed by persons who inherit the privilege.

The stegomyia does not breed in open swamps or large bodies of.water, but needs shelter, and is also incapable of sustaining a long flight. It breeds chiefly in and near towns, depositing its larvæ upon the surface of cisterns or stagnant pools.

Colonel W. C. Gorgas, M.D., took charge of the Department of Sanitation of the Commission in July, 1904. "The experience of our predecessors," he writes, " "was ample to convince us that unless we could protect our force against yellow fever and malaria we would be unable to accomplish the work."

At this time there was but little yellow fever on the Isthmus, and, in spite of the arrival of a large number of non-immunes, no alarming outbreak occurred during the first ten months. During April, 1905, however, the administration building in Panama, in which worked some 300 non-immune employees of the Commission, became infected.

* "Sanitation in the Canal Zone," by W. C. Gorgas Journ. Am. Med. Assoc., July 6, 1907, vol. xlix. 
In that month there were 9 cases and 2 deaths; in May, 33 cases and 8 deaths, of which 21 cases and 2 deaths were among employees of the Commission. In June there were 19 deaths from yellow fever on the Isthmus, and in July 13. The Commission reported ${ }^{*}$ that :-

"A feeling of alarm, almost amounting to panic, spread among the Americans on the Isthmus. Many resigned their positions to return to the United States, while those who remained became possessed with a feeling of lethargy or fatalism, resulting from a conviction that no remedy existed for the peril. There was a disposition to partly ignore or openly condemn and abandon all preventive measures. The gravity of the crisis was apparent to all."

Colonel Gorgas writes + of this time:-

"We could readily see that if the conditions as they existed in 1905 were to continue the Canal would never be finished."

And he adds that:-

$$
\begin{aligned}
& \text { * Annual Report, 1905, p. } 30 . \\
& \text { † "Sanitation in the Canal Zone." }
\end{aligned}
$$




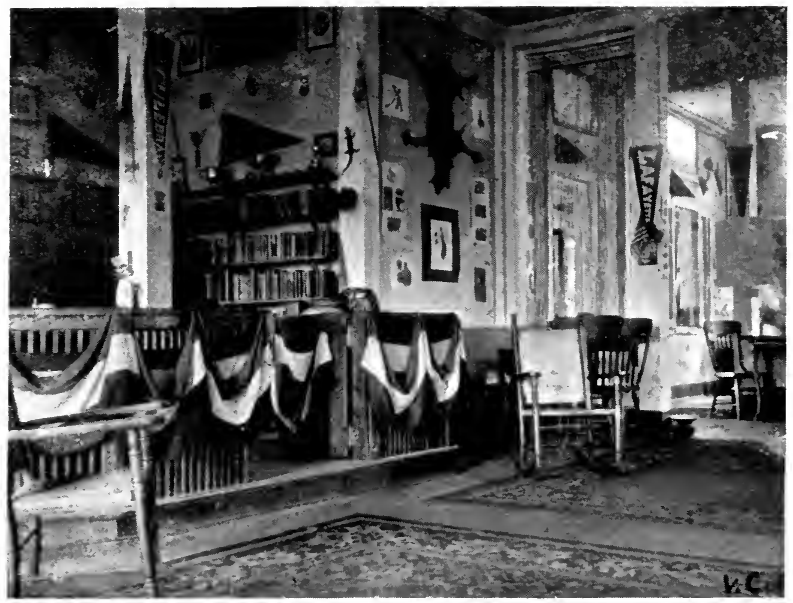

hali of employees' CLUb, CULEBRA.

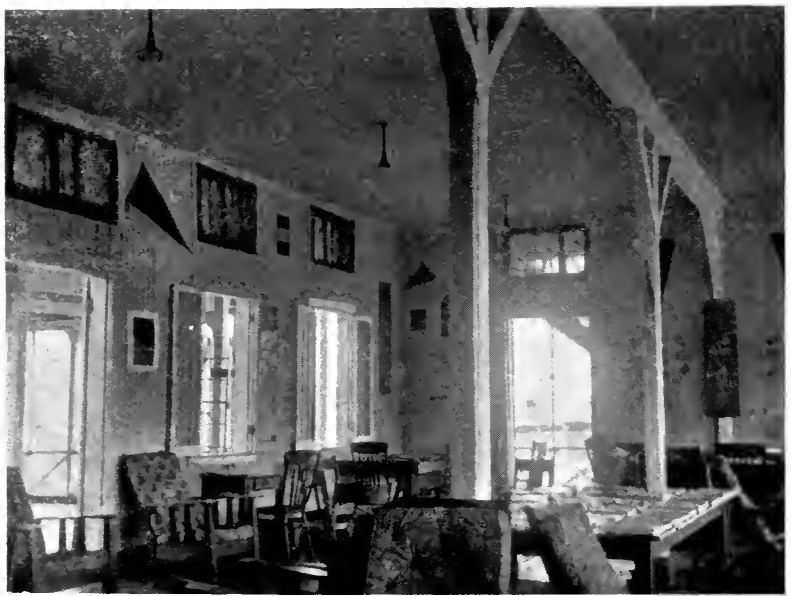

READING-ROOM, EMPLOZEES' CLUB, CULEBRA.

[To face pase I 26. 
$\therefore$ a 
"The Executive Board of the Commission itself, as late as June, 1905, stated that the sanitary work of the Isthmus had been a failure and recommended that the personnel be changed and other methods tried. But the Supreme Authorities . . gave us steady support, and by the following December yellow fever had disappeared from the Isthmus."

The total deaths among employees of the Commission from yellow fever during the 12 months October 1, 1904, to September 30, 1905, was 37 , among about $17,000 . *$ The total from yellow fever among the whole population, including Canal employees, during the four months May 1 to August 31, 1905, was 47 , while the number of deaths from malaria during the same period was 108. The effect of malaria in impairing physical efficiency was even more in excess than these figures indicate, for the fatal cases are a small proportion of the whole in malaria, and a very large proportion in

* In 1883-84 the French Company lost by yellow fever 66 men out of about the same number of employees. 
yellow fever. The moral effect of the imminence of the more sudden and fatal form of disease was, however, as these reports show, much the greater, and it was this moral effect which caused the crisis above described.

Previous to February, 1905, the Department of Sanitation had done little to improve the hygienic conditions of Colon and Panama, chiefly owing to the opinion until then maintained by the legal advisers that there was no authority to expend money in those cities, which are not within the Canal Zone.

In April the yellow fever broke out; the number of men employed by the Department of Sanitation was increased to the huge total of 4,100 , and the battle with yellow fever began in earnest. All cases were either transported to screened buildings, or, if left in their own homes, these were carefully screened with fine-meshed copper gauze. The object of this isolation was to prevent the patient from infecting healthy stegomyia mosquitoes.

Every dwelling in Colon and Panama was 
thoroughly fumigated with pyrethrum powder or with sulphur, and then cleared of dust and refuse, which, with the insensible but not always dead mosquitoes, was then burnt. The complete, and, it is hoped, final freedom from yellow fever in Colon and Panama has been obtained by means of a proper water supply and universal paving with brick or cement, as well as the supply of proper drainage. Formerly water for domestic use was stored in cisterns, tanks, tubs, jars, and so forth, and, after rain, water stood stagnantly in a thousand ruts and holes in the unpaved squares, streets, and lanes. These breeding-places of the stegomyia have now been done away with completely in Panama, and almost completely in Colon. The latter city is so low-lying and flat, and subject to such heavy rainfall, that pools of stagnant water will form. They can, however, be oiled, which kills the larvæ, and, moreover, it is Panama, and not the wind-swept, saltsaturated, town of Colon, which has been the chief source of yellow fever.

The last case of the disease in Panama 
occurred in November, 1905, and in May, 1906, there was an isolated case in Colon. The infection is considered to be at an end in a city three months after the last case, that being the lifetime of stegomyia. After this period, all infected stegomyia having died, those that remain are powerless for harm. Nevertheless, the stringent measures for their destruction are not relaxed, as, while stegomyia exists, the germ, if re-introduced, will be rapidly disseminated.

Thus the yellow fever, having taken toll for four hundred years of those who crossed the Isthmus, has been completely eradicated by Colonel Gorgas and his assistants. It is a triumph of science and of despotic government combined; and only in this combination can preventive medicine achieve full success.

There is one other aspect of the yellow fever campaign which must be mentioned before going on to describe the fight with malaria.

Yellow fever, unlike malaria, does not occur in all tropical countries. Its home is the West Indies, Central, and parts of South, 
America, and, before its extinction in Havana, it has been a serious scourge in the Southern United States. In the New World cases have occurred as far north as Quebec, in Europe cases have occurred in Wales and France, and there have been serious epidemics in Spain. It has never been known east of Genoa, whether in Europe or elsewhere. Thus in Africa it is known on the west but not on the east coast. The fact that it is unknown in India is very remarkable, seeing that stegomyia is a very prevalent variety of mosquito there. It follows from this that if yellow fever once got hold in India it would probably spread and might work great havoc. The same is true of China in an even greater degree, for such preventive measures as have been taken in Panama would be far more difficult to carry out in the great cities of India, and altogether impracticable in those of China. Thus, as Colonel Gorgas has pointed out, if the Canal had been constructed in spite of yellow fever, and if that disease had been allowed then to persist at Panama, the disease might not improbably 
have been carried to Asia, for the three months of life of stegomyia is ample for the voyage. In this event the Panama Canal might have proved a curse rather than a boon to mankind.

\section{Malaria.}

The campaign against malaria has been conducted on somewhat different lines. The anopheles, which transmits that disease, deposits its larvæ in clean water where grass and algæ grow, and is therefore almost entirely a mosquito of country districts. But Colon and Panama, both small cities, are exposed to the disease, as are about seventeen little towns and forty villages for labourers along the line of the Canal. As the flight of anopheles is not more than one hundred, or possibly two hundred yards, the working population can be in great measure protected from their attack by destroying the breeding places for such a distance on either side of the dwelling and working places. This in itself is a large task, which could not be carried out in a short time, and while in 


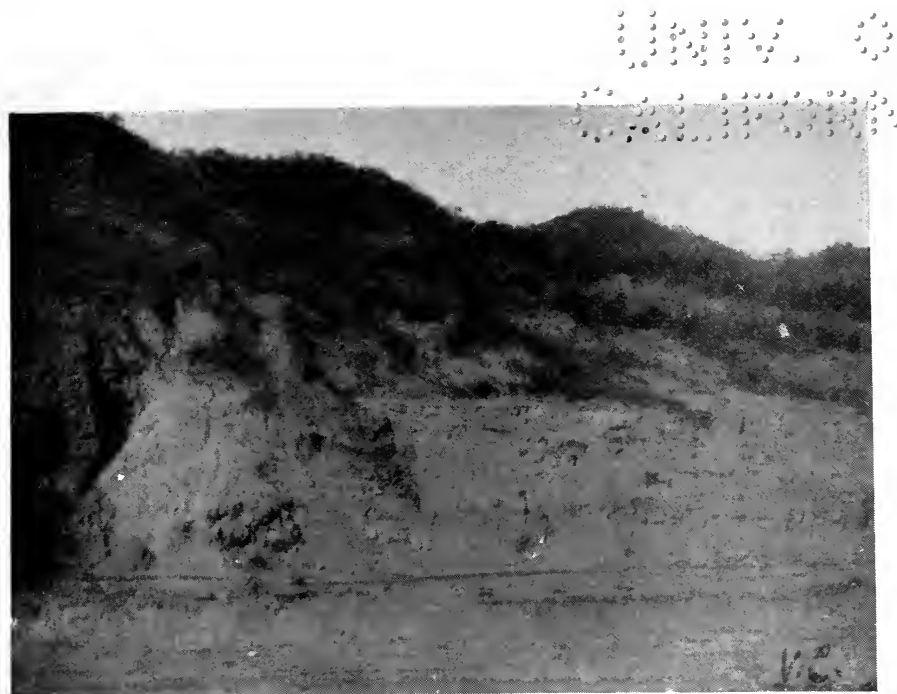

EAST FACE OF CUT, SOUTH OF CUIERRA.

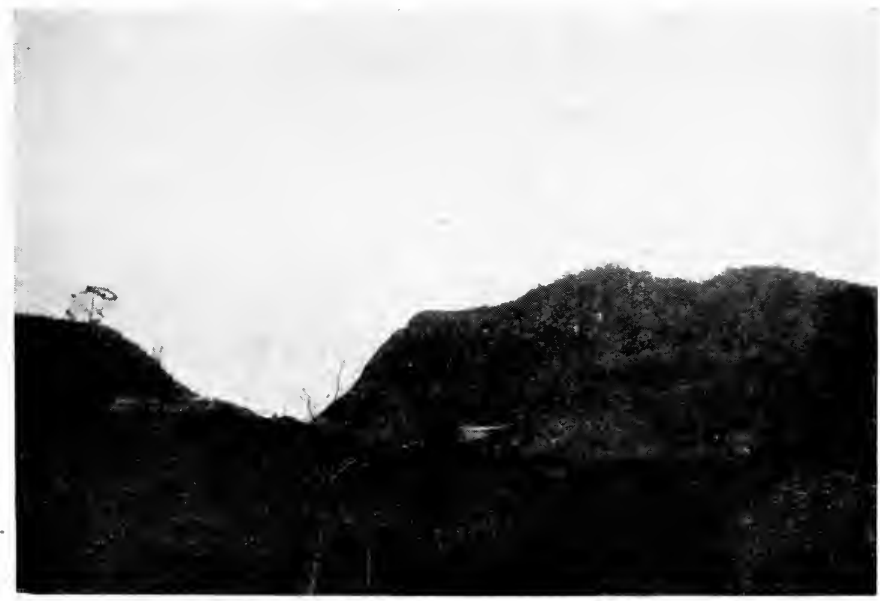

LOOKING NORTH, GOLJEN HILL ON THE RIGHT.

[To face page 132 . 
simand 
progress the Sanitary Department relied mainly upon the erection of buildings completely screened (including the verandahs) with fine copper gauze, which effectually shields the employees against mosquito attack within doors, and therefore during the particularly dangerous hours of night.

In addition, the employees are supplied with quinine, and recommended to take three grains daily while in health. This "cinchonises" the blood and renders it unwholesome to the malarial parasite.

The effect of screening is shown by the following example from the report of the Commission, December, 1906 :-

"The first shipload [of European labourers] arrived during the dry season, when mosquitoes were most scarce, and were quartered in unscreened buildings. Within six weeks of their arrival 33 per cent. of these labourers had been taken sick with malaria. The second shipload arrived during, the rainy season, and were quartered in a camp not 200 yards distant from that of their predecessors. The buildings of the camp were 
134 THE PANAMA CANAL AND ITS MAKERS

screened. Sickness among the men was infrequent, and when they had been upon the Isthmus six weeks it was found that only 4 per cent. had found their way to the hospitals."

The destruction of larvæ, and of their hiding places, is commenced by the clearing of grass and bushes, which are cut down with the machete, a short cutlass with which the Panamanian is very expert, machete work being, indeed, the principal rôle in which the Panamanian is employed by the Commission. Also ditches are cleaned out, and heavy oil poured upon the water in trenches and pools, and land-crabs are caught and the holes in which they dwell are filled in or oiled. Finally the soil is drained, which is the only means of making the ground permanently unfit for mosquito breeding. Subsoil draining is the best, a tile drain being put in ; for, even in concreted gutters, pools will form, owing to accidental obstruction, and remain sufficiently long for the deposition and hatching of the larvæ. Such is the work of the 
anopheles brigade, and the stegomyia brigade carry out similar operations, in the neighbourhood more particularly of Panama.

With regard to the effect of these operations upon the numbers of the mosquitoes I may narrate my own experience. I arrived at Colon first in January, 1907, and spent one or two nights on board my ship. This was two years and a half after the commencement of the mosquito campaign, and the officers of the ship congratulated themselves upon the absence of the swarms of mosquitoes which formerly attacked them at night on their vessel. I found, however, that although there was no swarm of mosquitoes, such as I have seen, e.g., when on board ship in the harbour of Colombo, Ceylon, yet that the individuals who remained certainly caused me discomfort, and I think some subsequent indisposition. In April, 1908, however, during two days at Colon, I did not so much as see a single mosquito.

At Panama, in January, 1907, my wife and I stayed in the Commission's screened hotel on Ancon Hill, not caring to face the dirt 
and squalor of the old city. In April, 1908, finding the city properly paved, drained, and plumbed, we took up our quarters at the Hotel Central in the town, where we spent a fortnight in perfect health; and although this building, not being under the Commission, is unscreened, I was only bitten by mosquitoes, to my knowledge, twice during that time, and this without subsequent ill effect. I may add that the picturesque surroundings, not unlike those of some city on the Mediterranean, greatly enhance the pleasure of a stay on the Isthmus, now that they can be enjoyed without squalid accompaniments. I did not, except on one or two nights, even draw the mosquito curtains. Out of doors, in the city of Panama, I was not bitten once, though I was attacked once or twice by solitary mosquitoes when walking on roads or paths with shrub or jungle adjoining. This was near the end of the dry season. When the rains commence a greater number of mosquitoes must be expected.

Natives of the Isthmus and the West Indies are not immune from malaria, and in 


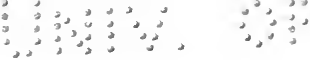

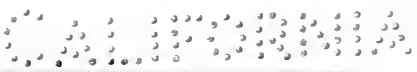

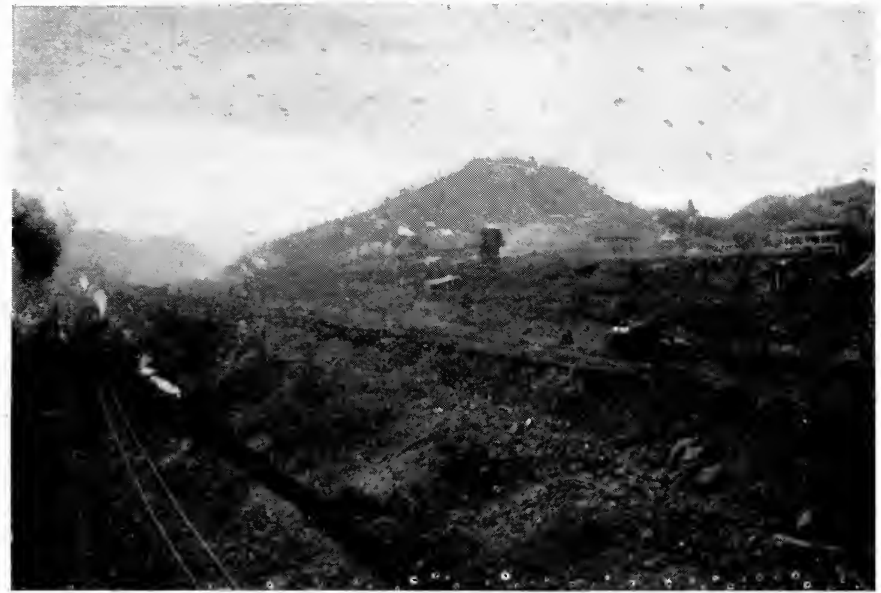

LOOKING NORTH FROM PARAISO.

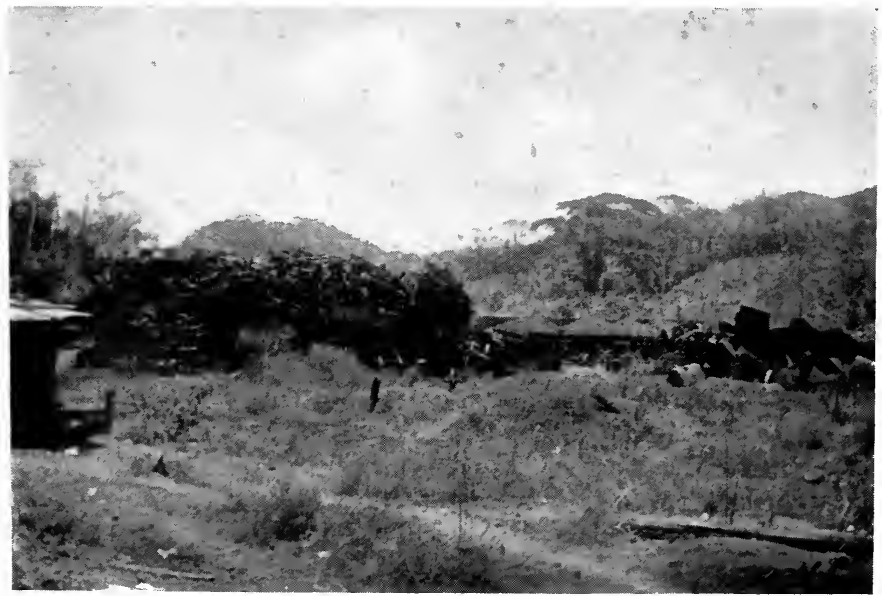

ABANDONED FRENCH MACHINERY.

[To face page $\mathbf{3} 3$. 

1904-5 about one-half of the inhabitants who were examined proved to have the parasite of malaria in their blood. As the anopheles becomes infectious through biting a malarious man, it is evident that such a dissemination of the parasite throughout the blood of the human population renders mosquitoes especially dangerous. In the same proportion as the population becomes less malarious, so the mosquitoes become less dangerous, and theoretically a millennium is possible in which man and anopheles, mutually purged of the malarial organism, may live happily together. Unfortunately, a malarious man it is believed remains infectious to anopheles for no less than three years, instead of the three days' limit of yellow fever, and this greatly increases the difficulty of exterminating malaria.

During 1906, with a force of 26,000 , there were 21,739 cases of malaria admitted to the Commission Hospitals, and the deathrate from this disease was among whites 2 per thousand, among negroes 8 per thousand. 
In 1907, with a force of 39,000 , there were 16,753 cases, the death-rate among whites being 3 per thousand and among negroes 4 per thousand. The increase among whites was due to the greater proportion of the European labourers, whose circumstances are different from those of the skilled artisans and the "screened" clerical staff of Americans.

The total death-rate from all causes in 1907 is shown below :-

\begin{tabular}{rr|r|r|r}
\hline & $\begin{array}{c}\text { Average } \\
\text { Number. }\end{array}$ & $\begin{array}{c}\text { Total } \\
\text { Deaths. }\end{array}$ & $\begin{array}{c}\text { Annual Death } \\
\text { Rate per } \\
\text { Thousand. }\end{array}$ \\
\hline White Employees & $\ldots$ & 10,709 & 179 & $16 \cdot 71$ \\
Black Employees & $\ldots$ & 28,634 & 953 & $33 \cdot 28$ \\
\hline Total & $\ldots$ & 39,343 & 1,132 & $28 \cdot 77$ \\
\hline
\end{tabular}

-but accidents account for a considerable proportion of the deaths.

During the same period the average number of American women and children in Commission quarters was 1,337, among whom occurred nine deaths, an average annual death-rate of 6.73 per thousand. 
In addition to malaria there is one other disease which proves fatal to considerable numbers of employees, attacking principally the black labourers. This is pneumonia, to which are attributed altogether 328 deaths as against 154 from malaria.

It appears that special research is needed into the cause and prevention of this disease among negroes in the tropics.

In 1907 no less than 71,000 persons arrived on the Isthmus, all of whom had to pass the Commission doctor at the entrance port. All but transients are vaccinated on arrival, and great watchfulness is exercised against the introduction of any new disease from abroad. Thus, when bubonic plague broke out at Guayaquil, the Department of Sanitation commenced a campaign against rats as a precaution against the spread of the disease (which is propagated by the rat flea) in case quarantine measures failed to keep it out.

Again, when one or two cases of rabies recently occurred on the Isthmus, all dogs 
140 THE PANAMA CANAL AND ITS MAKERS

for whom an owner could not be found were at once destroyed.

Life on the Isthmus, and on the Future of the White Man in the Tropics.

The Canal Zone now being healthy, the life of the Americans is a cheerful as well as a busy one. The climate, to which the local diseases used to be attributed, is not by any means wholly bad. There are really two climates, that of the Atlantic seaboard and that of the Pacific side. Colon is somewhat trying on account of the humidity, but a healthy trade-wind blows. The town of Panama, though receiving much less rain, is also somewhat humid, owing to there being less breeze. The temperature, however, is lower than that of the great cities of the United States, even in the North, during summer heat-waves, the hours of sunshine are shorter, and the general feeling of oppression is, I think, distinctly less. The Ancon suburb, where the Commission buildings are situate, is free from the humidity of the lowlying city. The high lands at or near 
Culebra, where a large part of the American population now resides in screened wooden buildings, enjoy in the dry season a bracing climate, a fresh dry wind blowing across the divide, imparting a sense of exhilaration, which is heightened by the fine scenery, the pleasant scents of the surrounding woodland, and the ordered activity of the life. Amidst such circumstances the Canal official finds it easy to work hard. I noticed in this a great contrast to the condition ten years ago at Ismailia, the headquarters of the Suez Canal Administration. This place, before Major R. Ross's discoveries, suffered severely from malaria, and the officials of the Administration, some of whom had resided there for twenty years or more, were in many cases saturated with malarial poison. Work for them was a burden, bravely borne indeed, but taken up each day with a sigh. I spent about a fortnight there in a hot season conducting some investigations upon the forms and movement of drifting sand-dunes. I suffered during part of the time from fever, and only kept on working with an effort, 
142 THE PANAMA CANAL AND ITS MAKERS

whereas on the Isthmus I enjoyed more than usual vigour. At Culebra, indeed, the dry season is so bracing that the arrival of the rains is welcome for the soothing effect of greater humidity, as well as on account of diminished dust. The white woolly cloud or mist which then wraps round the hill-tops is no longer the "white death," as it was called in the days of the French Company, when to vapours were credited the poison which really larks in the mosquito. Even now, however, there is an increase in the number of mosquitoes, and some increase in malaria, when the rains come.

Not only do the men look well, but the women and children also. The women in general have the same appearance as in the United States; perfectly dressed, as always, quiet in manner, and apparently happy, though occasionally somewhat bored. To the wife, not having the absorbing interest of the Canal work, the Isthmus is generally less interesting than to her husband, but of late there have grown up organisations for promoting intellectual and other social inter- 


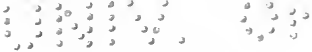

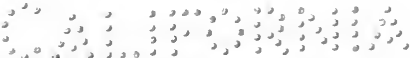

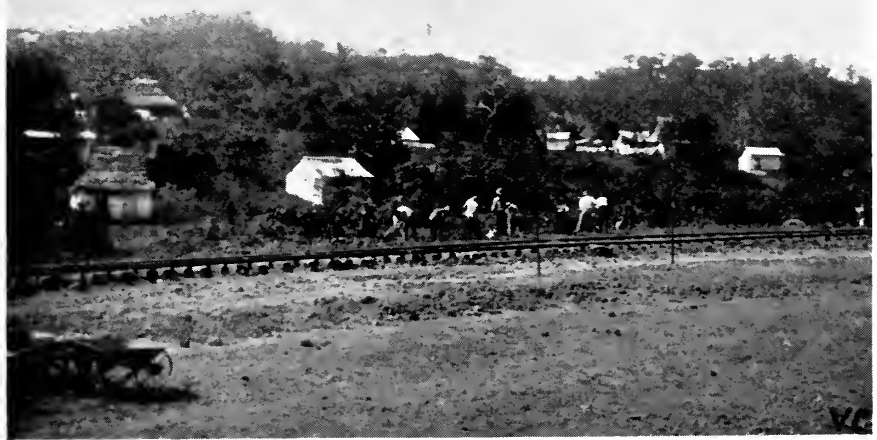

G.NG OF EUROPEAN LABOURERS IN 1907.

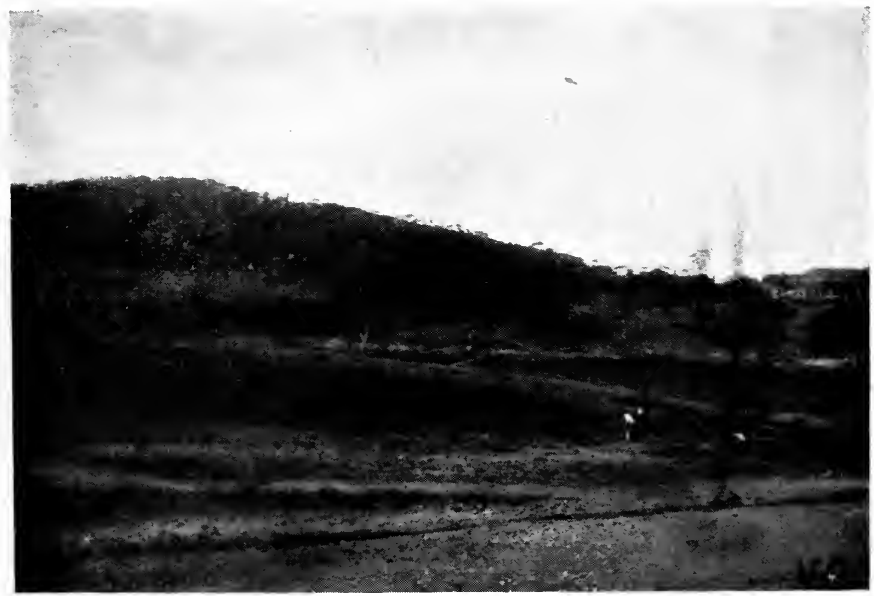

FORMER HOT-BED OF MALARIA, NOW DRAINED.

[To face page 142. 


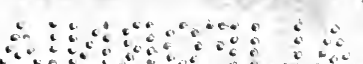


course which are rapidly relieving the threatened ennui.

The children, on the other hand, look actually happier and stronger than they do in the cities of the United States. They are in the open air all day, for sunstroke is rare on the Isthmus; they are bronzed, active, fearless in bearing, and apparently thoroughly satisfied with themselves and with their surroundings. Even when within doors they are still in a sense in the open air, for the windows are unglazed, and the houses are constructed so as to secure a free circulation of air.

It has been said that the possession of India taught the English the value of the cold bath, an institution which has been slowly adopted from us by other Northern nations in Europe. Perhaps the possession of the Canal Zone will lead to the salutary open-window habit, which is not yet general in the United States.

The Commission clubs for gold-employees at the principal stations are commodious structures, admirably designed for social 
144 THE PANAMA CANAL AND ITS MAKERS

recreation; their management is entrusted to the Young Men's Christian Association. There are well-equipped reading and writing rooms and gymnasia, mainly used by the men, but the interests of the women and children are not neglected, and for the last playrooms are provided. The large halls are used for entertainments and for meetings of the numerous benevolent "secret" societies which have been so important a factor in the preliminary organisation of American society in newly settled territories. In the clubs only "soft" drinks are provided, but I can testify to their excellent effects.

The question whether the white race can make a home in the tropics depends ultimately upon the tropical baby-upon his own health and that of his mother. The American occupation is still recent, but as far as experience goes it seems that the white children born on the Isthmus have not shown unusual delicacy, and the mothers have made a normal, though sometimes rather slow, recovery from confinement.

The views of Colonel Gorgas upon the 
future of the white race in the tropics deserve quotation. $\mathrm{He}$ writes * :-

"I think the sanitarian can now show that any population coming into the tropics can protect itself against these two diseases [malaria and yellow fever] by measures that are both simple and inexpensive; that with these two diseases eliminated life in the tropics for the Anglo-Saxon will be more healthful than in the temperate zones; that gradually, within the next two or three centuries, tropical countries, which offer a much greater return for man's labour than do the temperate zones, will be settled up by the white races, and that again the centres of wealth, civilisation and population will be in the tropics, as they were in the dawn of man's history, rather than in the temperate zone, as at present."

In this connection I may perhaps be permitted to refer to an interesting suggestion made in the course of conversation by Colonel Gorgas, although I omitted to inquire if it had been published. This suggestion was * "Sanitation in the Canal Zone." 


\section{THE PANAMA CANAL AND ITS MAKERS}

that the records of the movements of great armies under the rulers of ancient Mesopotamia and Egypt indicate that malaria did not then exist in the nearer East, and that malaria, like yellow fever, was once a local disease.

From what I have seen as tourist and traveller (not as resident) in the West Indies and in the Orient, I have arrived at the following tentative conclusions, viz. :-

That the debilitating effect which the tropics have been observed to exercise upon those who come from temperate regions has been due mainly to the presence of certain diseases which can be done away with.

That the rapid deterioration of the white stock which is usually noticed in the tropics, especially near the equator, is mainly due to the same cause.

But that Anglo-Saxons cannot perform nearly the same amount of hard bodily labour in a constantly hot climate as they can in the temperate zone, and Anglo-Saxon immigrants never will be able to do so. In this I think the Mediterranean races-at all 


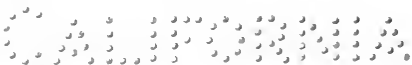

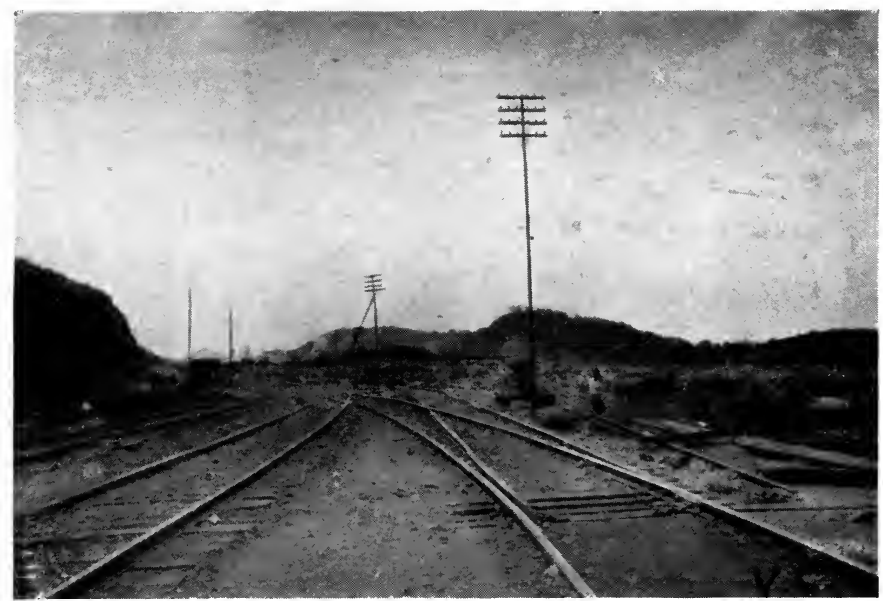

NEAR TIE SITE OF MIL.AFLORES LOCKS.

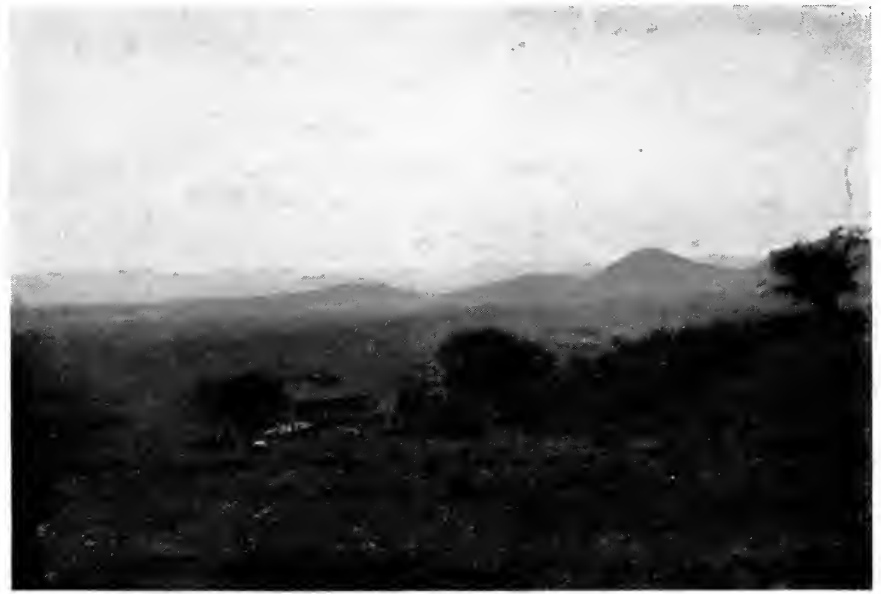

NORTH TO CULEIBA DIVIDE FROM ANCON HILL.

[To face page I46. 


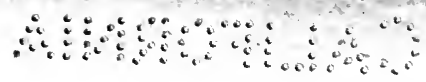


events the Spaniards and Italians-are our superiors.

Whether the descendants of Anglo-Saxon stock who have settled in a tropical country purified from tropical diseases will be able to support continued hard bodily labour better than their immigrant ancestors is a matter about which we have at present no direct evidence.

It may possibly be worth noting, however, that some years ago, when wintering in Manitoba, I found that some of the farmer immigrants from England felt the cold more as the years went by, but that their children born in the country were unaffected by it.

It is the case that in the tropics, particularly in the equable equatorial belt, many evils of the temperate zone are avoided, chiefly those due to cold and to sudden changes of temperature. It is this equatorial beit of equable temperature and heavy rainfall that I chiefly have in mind, for it comprises those vast regions of prolific vegetation which appear capable of supporting so large a population. 
The white man already rules, or has marked off for rule, the whole of the equatorial belt, but who is to be the peasant cultivating this belt? In those parts of tropical Asia already peopled by industrious Orientals there can never be a white peasantry. Equatorial Africa presents great differences in different parts with respect to native population, and the question of a possible future for white peasantry is there a complicated one. In South America, however, there are vast equatorial regions either wholly unpeopled, or sparsely inhabited by tribes of that Indian stock which has elsewhere proved so slight an impediment to the establishment of the white labourer. Served by a system of rivers unrivalled elsewhere in equatorial regions, already partitioned among Christian Governments, and for the most part uninhabited, the forests and savannahs of Equatorial South America offer the readiest field for the establishment on a vast scale of a white peasantry under the equator.

By clearing the scrub within one or two hundred yards of his cottage, and by em- 
ploying wire screens, the cultivator can protect himself against malaria, and his crops come not once, but several times a year.

If the Spanish, Portuguese, and Italian peasant were to turn his attention to this field, instead of, or in addition to, that of navvy work, great things might come of it. The circumstance that South America is a Roman Catholic continent, where the Latin races are dominant, would enormously favour the experiment. On the Zone, the Spanish labourer works in order to save and to depart, the milieu being foreign to him and unattractive. In a Latin State it would be different.

In writing of the possibilities of the white race in the equatorial zone it is understood that the problem relates to the lowlands. There are, of course, favoured highlands, such as those of Colombia, where the temperature is at the same time moderate and equable and the climate appears admirably adapted to white men.

A healthy city life in the tropics would be easily attainable in a new country settled 
150 THE PANAMA OANAL AND ITS MAKERS wholly by white people and under a medical despotism.

The general, but non-specialist, opinion upon the Isthmus is not as sanguine as that of Colonel Gorgas upon the hygienic future of the white race in the tropics. The general opinion among Americans seems to be that, as far as they are concerned, they would, if engaged in the tropical parts of South or Central America, avail themselves of the improving means of transit to revisit frequently the United States, and would rely upon such vacations in higher latitudes for the retention of their native vigour. 
ON THE SHORTENING OF DISTANCES BY SEA, AND ON THE STEAMSHIPS AVAILABLE FOR CANAL TRANSIT 



\section{CHAPTER VI}

ON THE SHORTENING OF DISTANCES BY SEA, AND ON THE STEAMSHIPS AVAILABLE FOR CANAL TRANSIT

The Shortening of Distances by Sea.

$A \mathrm{~S}$ the sole object of a ship canal is to 1 shorten sea distances, the figures given in this section are of primary importance to a proper understanding of the subject. The figures here given are those for steamships following the actual or prospective routes. They are adopted from the figures supplied to the Canal Commission from the United States Hydrographic Bureau and are expressed in nautical miles. It is perhaps not wholly superfluous to warn the reader that the apparent relative distances as shown on charts of the world, especially those on the 
usual Mercator projection, are very different from the real relative distances. Moreover, it is impossible to see correctly the relative distances between places far apart on a globe, for the foreshortening of the rounded surface produces distortion. By applying a measuring tape to the globe the true relative distances can be readily ascertained. This is a salutary exercise and serves to correct the erroneous notions which tend to fix themselves in the minds of all of us owing to the appearance of the surface of the globe on the plane of the paper or on the plane of vision. Such a measurement of shortest distances would give a very fair notion of the actual reductions due to the Suez and Panama Canals, but there would still be considerable differences between these figures and the distance calculated from the actual courses pursued by steamships, which in what follows will be referred to simply as "the" distance between ports.

The most notable effect of the Panama Canal will be the reduction of distance between the Atlantic and Pacific ports of North 


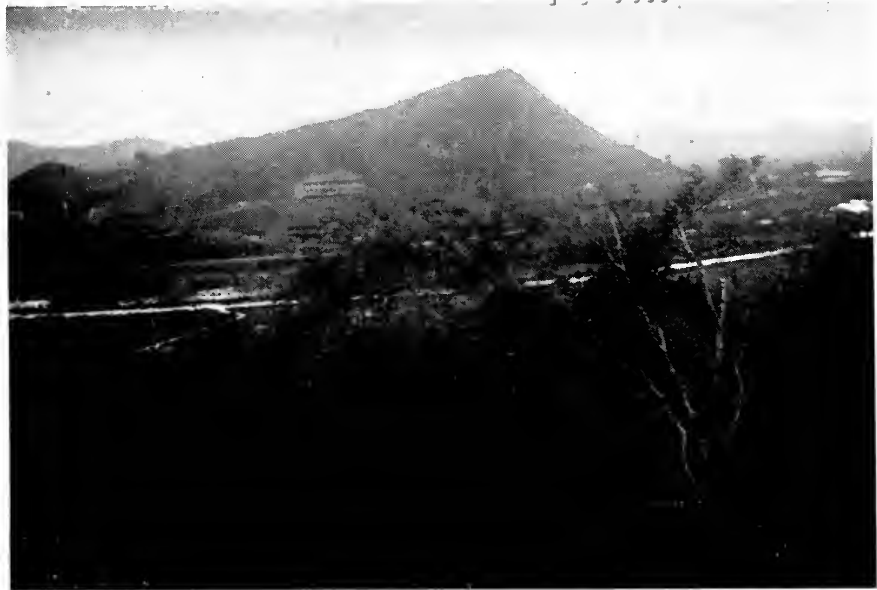

RIO GRANDE, NEAR LA BOCA.

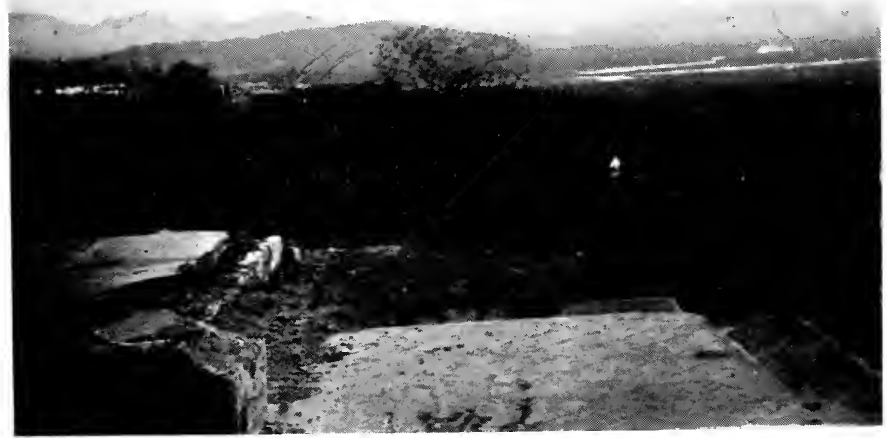

- RIO GRINTE, FRON ANCON HIIL.

[To face pasc 154 . 
4
4 
America. Taking New York as our port of reckoning on the Atlantic, the distance thence to Panama and all ports north thereof on the Pacific seaboard of Central and North America will be reduced by 8,415 miles.

The reduction of distance from New York to the Pacific ports of South America, on the other hand, is not constant, but varies from the above maximum of 8,415 miles at Panama to a minimum of about 1,004 miles at Punta Arenas (in the Straits of Magellan). The average shortening on this coast is therefore

$$
\frac{8,415+1,004}{2}=4,709 \text { miles. }
$$

The actual shortening to Iquique, the nitrate port in Chile, is 5,200 miles. We shall not be far out in saying briefly that the distance between New York and South American Pacific ports will be shortened by an average of 5,000 miles.

The Canal shortens the distance between the Pacific coast of the Americas and the ports of Europe also, though in a lesser degree. Thus, taking Liverpool as our ex- 
ample (and the reductions are much the same for London, Antwerp, or Hamburg), the Canal will shorten the distance to Panama and all ports on the coast to the north by a constant quantity, viz., 6,046 miles.

The reduction to Pacific ports south of Panama is not a constant but a variable quantity, ranging from the above maximum of 6,046 miles at Panama itself to zero at a point between Punta Arenas and Coronel (the most southern industrial port of Chile). We may put the average shortening of distance between Liverpool and South American Pacific ports at about 2,600 miles.

Viewing the whole matter from the standpoint of the Pacific ports of the Americas, we see an absolute commercial advantage accruing to them all in the diminished distance to the Atlantic and Gulf ports of North America and to the ports of Europe. Viewing the matter from the standpoint of the Atlantic and Gulf ports of North America-to fix our ideas we will say from the standpoint of New York-we see the 
same absolute advantage plus a competitive advantage, in that the reduction is greater for New York than for. Liverpool (i.e., Europe).

As the world is at present constituted, steamers from New York and from Liverpool proceeding to these Pacific ports all pass Pernambuco, in Brazil, near the easternmost point of South America, not far south of the equator. This port is 4,066 miles from Liverpool and 3,696 miles from New York, so that, by sea, San Francisco is only 370 miles nearer to New York than to Liverpool. But Colon is 4,720 miles from Liverpool and only 1,961 from New York, so that viâ the Canal all the Pacific ports of the Americas are 2,759 miles nearer to New York than to Liverpool.

Let us next consider the Canal as the starting place for Transpacific voyages, the rôle for which it was originally projected in the sixteenth century. In those days the Isthmus of Suez was firmly held by the hostile Moslem, and even if a canal had then been open there, 
it would not have been available for the commerce of Christian Europe. Thus the discovery of a strait, or the cutting of a canal, at the Isthmus of Panama would at that time have opened to Europeans a shorter seaway to the Orient. But now that the Suez route has been opened for ships, the Panama Canal will not bring any port in Australia or the East Indies, nor any ice-free port in Asia or Asiatic Islands, nearer to any European port. Of all ports on the west, that is to say the Old World or "Oriental" side, of the Pacific, only those of New Zealand and some in Siberia will be brought nearer to Liverpool, and that to an insignificant amount.

Distances are, however, much diminished between New York and both the northern and the southern ports of the Oriental Pacific coasts, as the following table shows :-

New York to-

Reduction.

\begin{tabular}{|c|c|c|c|c|c|}
\hline Yokohama & $($ by Suez $\ldots$ & & & $13,564\}$ & 3,729 miles. \\
\hline & by Panama & & $\cdots$ & 9,835 & \\
\hline Shanghai & $\left\{\begin{array}{l}\text { by Suez ... } \\
\text { by Panama }\end{array}\right.$ & $\ldots$ & $\ldots$ & $\left.\begin{array}{l}12,514 \\
10,885\end{array}\right\}$ & 1,629 miles. \\
\hline Sydney & $\begin{array}{l}\text { by Cape of Good } \\
\text { by Panama (viâ }\end{array}$ & $\begin{array}{l}\text { Hope } \\
\text { Tahiti) }\end{array}$ & & $\begin{array}{r}13,658 \\
9,852\end{array}$ & 3,806 miles. \\
\hline Melbourne & $\begin{array}{l}\text { by Cape of Good } \\
\text { by Panama (viâ }\end{array}$ & $\begin{array}{l}\text { Hope } \\
\text { Tahiti) }\end{array}$ & & $\begin{array}{l}13,083 \\
10,427\end{array}$ & 2,656 mile \\
\hline $\begin{array}{l}\text { Wellington, } \\
\text { N.Z. }\end{array}$ & $\left\{\begin{array}{l}\text { by Straits of Ma } \\
\text { by Panama (viâ }\end{array}\right.$ & $\begin{array}{l}\text { gellan } \\
\text { Tahiti }\end{array}$ & & $\begin{array}{r}11,414 \\
8,872\end{array}$ & $2,542 \mathrm{mi}$ \\
\hline
\end{tabular}




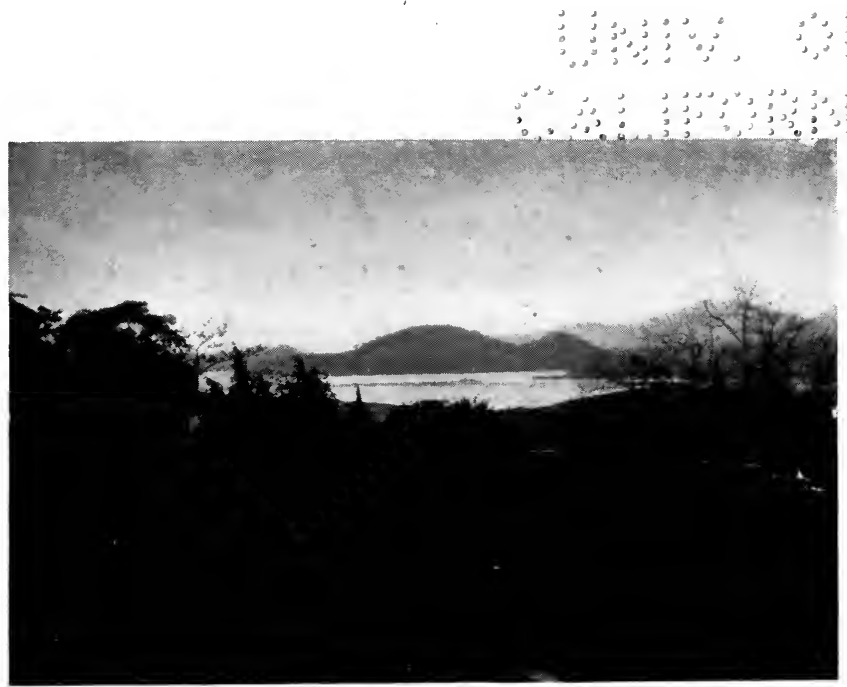

LA BOCA, FROM ANCON HILL.

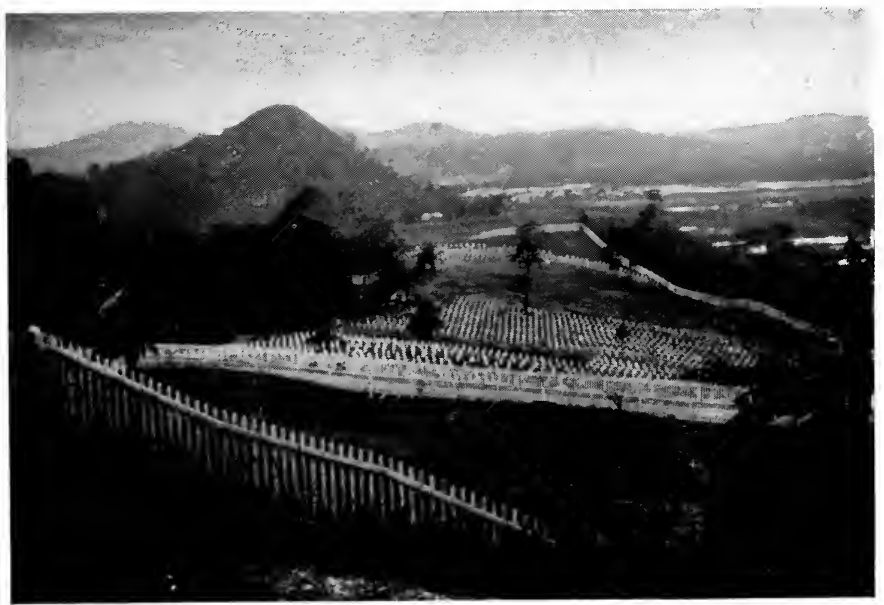

THE CEMETERX AT ANCON.

[To face fage I58. 

Since the Canal does not reduce the distances between these places and Europe (except slightly in the case of Wellington), the competitive gain of New York is equal in all cases to the absolute gain in distance. The following figures show the distances from New York to Hong Kong and Manila by the Suez and Panama routes:

New York toReduction.

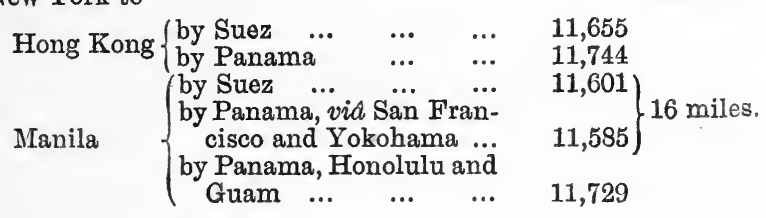

Ports on the mainland of Asia in these latitudes are of course nearer to New York by way of Suez.

The opportunities of a port for commerce obviously depend in a great measure upon the centrality of its position with reference to the other ports of the world. Let us see how Liverpool and New York were originally situated in this respect, and how far their situations are altered first by the opening of the Suez route and secondly by that of 
Panama; remembering also that the changes introduced by the canals have about the same effect on Antwerp or Hamburg as on Liverpool.

Prior to the opening of the Suez Canal in 1869 the route to Asia and Australia was viâ the Cape of Good Hope from both Liverpool and New York. This gave Liverpool an advantage of 480 miles for all Asiatic and Australian ports as well as for the East Coast of Africa. For most of South America and all the Pacific coast of the Americas the route was via Pernambuco, and New York had an advantage of 370 miles. .

Suez being open but Panama still closed, the route to Asia is via Gibraltar for both Liverpool and New York. New York is distant 3,207 miles and Liverpool 1,283 from that place, so that Liverpool has an advantage of 1,924 miles instead of 480 on the voyage to all Asiatic ports, a competitive benefit of 1,444 miles resulting from the opening of the Suez Canal.

The voyage to Australia from New York being still made viâ the Cape of Good Hope, 
while that from Liverpool is most shortly made by Suez, Liverpool is 1,622 miles nearer by the canal and 480 by the Cape, thus obtaining a benefit of 1,142 miles when the Suez route is taken.

The opening of the Panama route leaves unchanged the relative distances to the Atlantic coast of South America, to Africa, and to Asiatic ports south of Shanghai; but it is New York and not Liverpool which is now the nearer port to Yokohama, Sydney, and Melbourne; and Wellington, New Zealand, formerly nearly equidistant, is placed 2,739 miles nearer to New York than to Liverpool.

With reference to Northern China, however, it is to be noted that, although the Panama route shortens the distance between New York and Shanghai by 1,629 miles, Liverpool will still be the nearer to Shanghai by 295 miles, assuming the New York vessel to call at San Francisco.

These facts are illustrated by the figures given on the next page. 
Nearer to

New York than

Yokohama $\left\{\begin{array}{l}\text { New York viâ Panama, } \\ \text { San Francisco and by } \\ \text { Great Circle ... } \\ \text { Liverpool viâ Suez, Adē, } \\ \text { Colombo, Singapore, } \\ \text { Hong Kong and } \\ \text { Shanghai ... ... }\end{array}\right.$ to Liverpool by

Sydney $\left\{\begin{array}{l}\text { New York viâ Panama } \\ \text { and Tahiti ... } \\ \text { Liverpool viâ Suez, Aden, } \\ \text { Colombo, King George's } \\ \text { Sound, Adelaide and } \\ \text { Melbourne ... ... }\end{array}\right.$

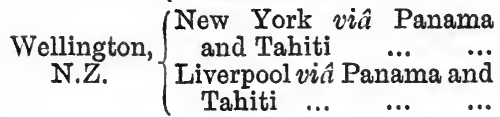

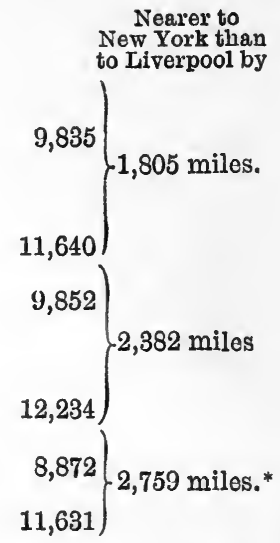

* Liverpool to Colon, 4,720; New York to Colon, 1,961: difference, 2,759 , the subsequent routes being identical.

Let us take a chart of the world and examine the portion comprised between the parallels of $40^{\circ}$ North and $40^{\circ}$ South and the meridians of $120^{\circ}$ East and $160^{\circ}$ East of Greenwich. This band, in which are included Japan and Korea, Shanghai and the Philippines, New Guinea and most of Australia, is of particular interest in relation to Canal trade. Let us take the standpoint, not of Europe or of America, but of traders residing in this area. Near its western margin the Suez and the Panama routes to New York are equal in length. 


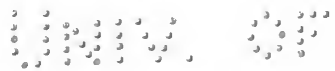

$$
\begin{aligned}
& \Rightarrow
\end{aligned}
$$

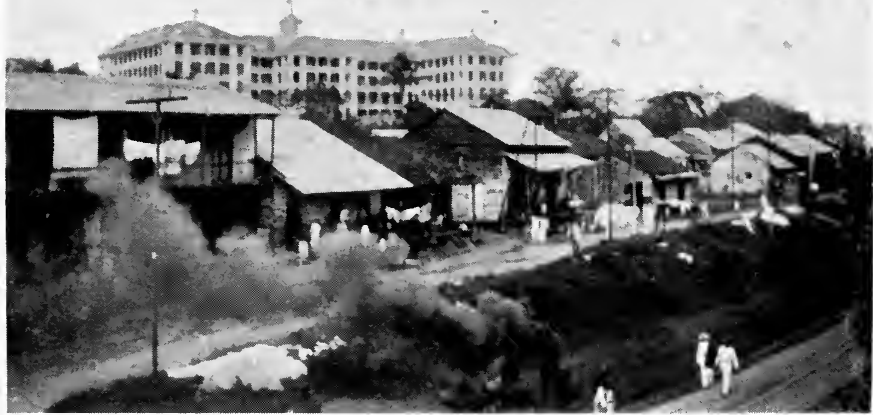

COMIMISSION'S HOTEL AT ANCON.

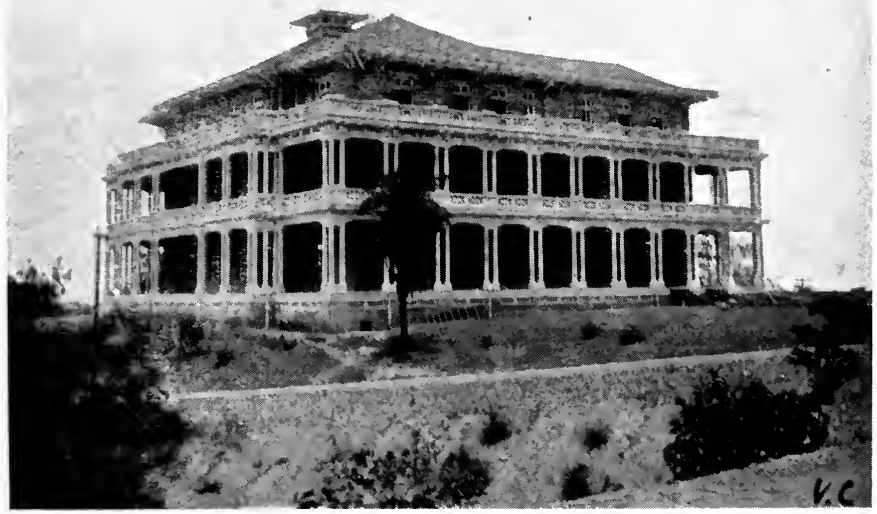
ADMINISTRATION BUILDING, ANCON.

[To face page 162. 
$\therefore$ 
Near its eastern margin, which lies, however, outside Japan and Australia and only passes among small islands, the Suez and Panama routes to Liverpool are of equal length.

On a line rather west of the centre and running from rather west of north to rather east of south, all places are equidistant from New York and Liverpool-the latter via Suez, the former via Panama.

It needs no prophet to foresee interesting commercial developments in a region where the alternative routes and alternative sources of manufacturing supply offer almost equal allurements.

I must also draw attention to the position of New Orleans and other ports on the Gulf of Mexico in relation to the Canal. At present New Orleans by sea is further than New York from Valparaiso and San Francisco, Yokohama and Shanghai, but it is 581 miles nearer to Colon. Hence, when the Panama Canal is open it will be 581 miles nearer than New York to those ports, and to Sydney, Melbourne, and Wellington. 
Thus, as the Mississippi waterway is improved, an increasing proportion of the manufactures and other products of the great Mississippi basin will find their way to foreign markets via the Gulf ports, and an increasing proportion of imports will find their way to the Mississippi basin through these ports.*

In dealing with the shortening of sea routes it was shown that the greatest reduction was that between the two coasts of North America, but even so the sea route remains longer than that by land, so that the question of commercial advantage is not settled by a mere statement of sea distances, and the indisputable and undiluted advantages of the Canal route for the Atlantic and Gulf

* Among West Indian ports affected by the Canal, Kingston, Jamaica, must be particularly mentioned. Now situate at the entrance of a cul de sac, it will then be placed in a position of much greater centrality for the world's commerce, and astride the route from Colon to the North American Atlantic ports. Thus the importance of Jamaica as a constituent of the British Empire will be enhanced. May the opening of the Canal increase the prosperity of our fellow subjects who have suffered so greatly from hurricane and earthquake! 
ports of North America are those of commerce with the Pacific coast of South America, with New Zealand, Australia, Japan, Northern China, Manchuria, and Eastern Siberia.

From the naval point of view, however, the results of shortening the sea distance from New York to San Francisco are scarcely diminished by the fact of railway communication, since only crews and stores, and not warships, can be transported by rail.

In order to understand the effect of the Canal upon the naval position of the United States the student of affairs must, in addition to the information given above, examine the positions relatively to the Canal of the possessions, particularly the insular possessions, of the United States and of other naval Powers. This will enable him to gauge for himself the more permanent factors which determine the value of the new line of communication, the opportunities it affords for concentrating force where wanted, and the responsibilities of defence which it entails. With the aid of a fairly good atlas this can 
166 THE PANAMA CANAL AND ITS MAKERS

easily be done by anyone acquainted with the general facts of naval power at the present time. The geographical facts, which are perhaps the only ones beyond question or dispute, are sufficiently simple.

On the Steamships Available for Canal Transit.

The Isthmian Canal Commission, in the Report of 1899, distinguishes between the commercial and the industrial benefits of the Canal, meaning by the former term the increased carrying of goods, and by the latter the development of production induced by improved facilities of carriage.

The tables of distances already given show the potential commercial advantages, and how they are distributed $n$ different measure among different countries, and these figures have all the permanence which makes geographical figures of such enduring importance.

But the actual commercial advantage of a ship canal depends equally upon a second factor, viz., the available ship-tonnage. Supposing a Panama Canal to be open at 


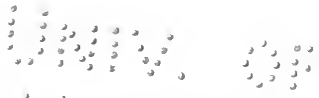

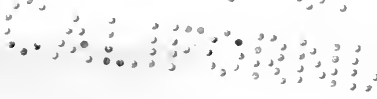

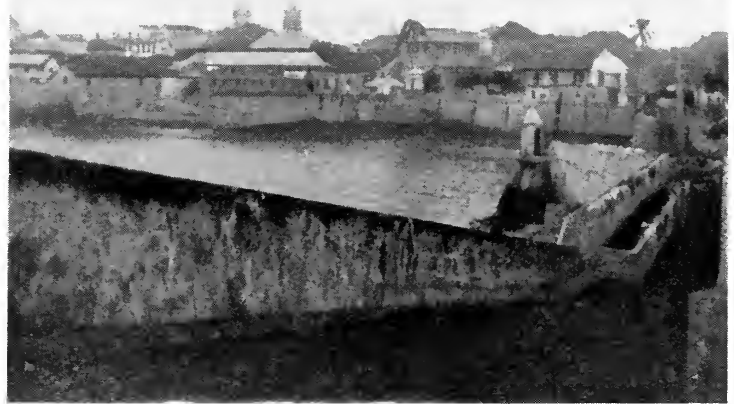

VIEW FROA SPAXISH FOR'T, PANAMA.

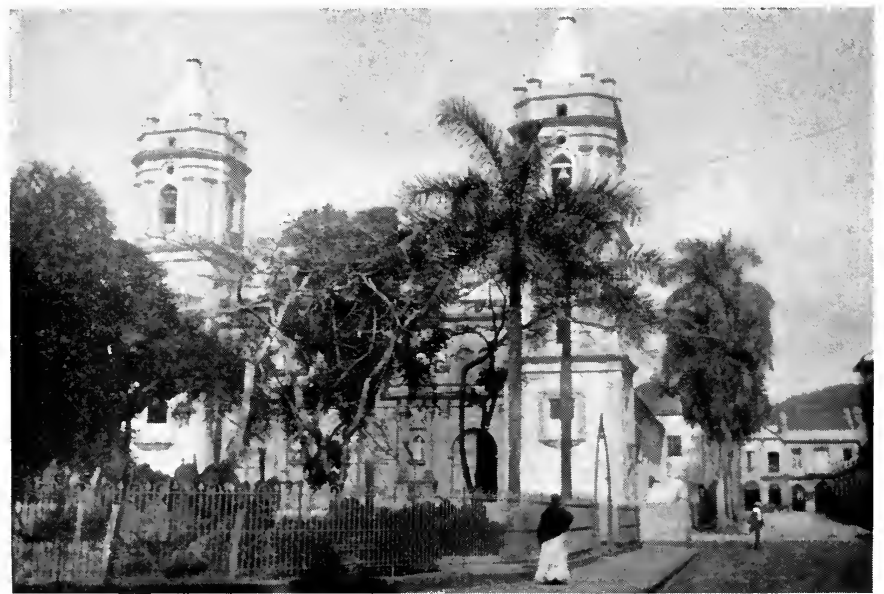

CATHEDRAI SQUARE, PANAMA.

[To face page 166. 

the present time, there would be hardly any United States ships to use it, except in transport between home ports from which ships flying foreign flags are debarred. The transport to South America, New Zealand, Australia, Northern China, and Japan would necessarily be almost wholly carried on by ships of other nations, especially British.

The absence of an American merchant marine trading with foreign ports is indeed a circumstance without parallel among other nations engaged in modern manufacture. Many interesting facts relating to this strange phenomenon were put on record in the debates of the United States Senate in the early part of $1908 .{ }^{*}$

At that time there was not one steamship flying the flag of the United States between her ports and those of Brazil, the Argentine, Chile, or Peru.

The three steamships of the Oceanic Line formerly plying to Australia were then laid up in the harbour of San Francisco, being unable, although subsidised for mails by

* Congressional Record, February 24, 1908. 
the United States Government, to compete with foreign vessels. There were, however, three United States steamers plying from Puget Sound to Japan and China, occasionally reaching the Philippines.

The mails from New York and the other Atlantic ports of the United States to Brazil and the Argentine go via Europe, so that in this important matter New York is actually 3,000 miles further than Europe, instead of being 370 miles nearer to those countries.*

In the same debate Senator Depew said that ships receiving the United States mail subsidy, the only form of subsidy given, have to be American built, manned by Americans, and the diet of the sailors as prescribed by law. He added that-

"The labour unions have rightly and properly taken care of their wages. The result is that the cost in wages and food to run American ships under American conditions across the Pacific is double that of European or Japanese steamers."

The relative cost of operating American * Senator Gallinger, loc. cit. 
and European vessels was given by the Hon. Elihu Root, Secretary of State, in an address delivered November 30, 1906, ${ }^{*}$ as follows:-

The operation of an American steamship of 2,500 tons costs $\$ 18,289$ per annum more than that of a British ship of this tonnage, or $\$ 7.31$ more per ton; and

The operation of an American steamship of 3,500 tons costs $\$ 15,315$ per annum more than that of a German ship of the same size, or $\$ 4.37$ more per ton.

Thus it is evident that, in spite of geographical advantages, there are at present some grounds for the extreme opinion sometimes expressed in the United States that the Canal is being built with American money for the use of Europe-and, one may add, of Japan.

What attempts may be made to remedy this state of things, and what effects such attempts may have, are matters on which I shall not stay to speculate.

* Address to Mississippi Commercial Congress, Kansas City, revised by Mr. Root and published Nat. Geogr. Mag., 1907, vol. xviii. pp. 61-72. 



\section{THE COST OF THE CANAL}





\section{CHAPTER VII}

THE COST OF THE CANAL

$\mathrm{F}^{\mathrm{F}}$ the existing canals for ocean-going ships, that of Suez was built by a company as a commercial undertaking to earn dividends by tolls. It cost $\$ 90,000,000$.

The Manchester Ship Canal was partly commercial, partly industrial, i.e., the large contribution of the city of Manchester was made not as a financial speculation, but in order to promote an undertaking likely to develop the industries of the city. This canal, partly commercial, partly industrial, cost $\$ 75,000,000$.

The Kiel Canal has further a military purpose, providing a short line of communication for warships. It cost $\$ 40,000,000$. The Panama Canall is commercial, industrial, 
174 THE PANAMA CANAL AND ITS MAKERS

and military, and will cost more than all the above put together.

Up to June 30, 1908, the United States Government have spent $\$ 126,047,062$ on the Panama Canal, made up as follows:-

Payment to New Panama Canal Company $\$ 40,000,000$, and to Republic of Panama $\$ 10,000,000 \$ 50,000,000$ Expenditure on work prior to July

$$
1,1907 \ldots \quad \ldots \quad \ldots \quad \ldots \quad 43,172,408
$$

Expenditure on work July 1, 1907June 30,1908 ... $\quad \ldots \quad \ldots \quad 32,874,654$

$$
\text { Total } \quad \ldots \quad 126,047,062
$$

The amount authorised to be appropriated by the Act of June 28, 1902, was $\$ 135,000,000$, plus $\$ 50,000,000$ purchase money, that is to say, $\$ 185,000,000$ in all, for "the canal, harbours, and defences."

What the total cost will be is unknown, but Colonel Goethals stated in evidence (January, 1908) that the Canal would cost at least $\$ 250,000,000$, and possibly as much as $\$ 500,000,000$. 


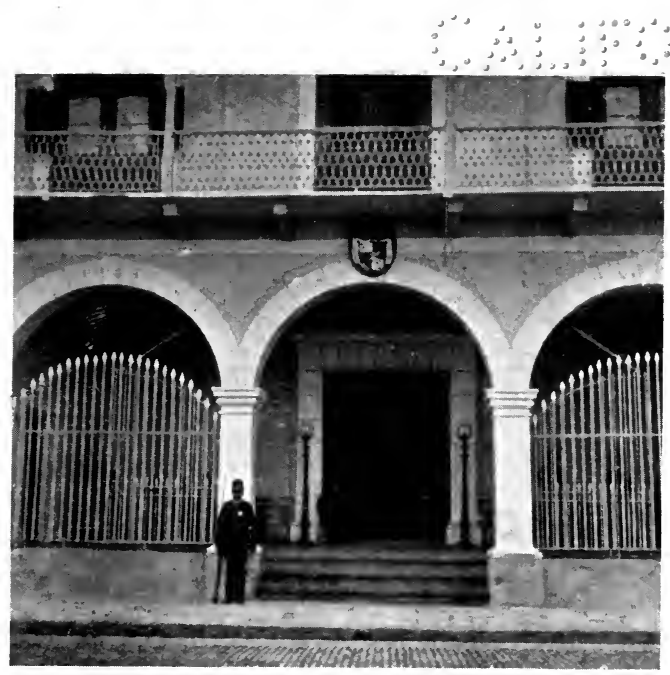

PALACE OF THE PRESIDENT OF PANAMA.

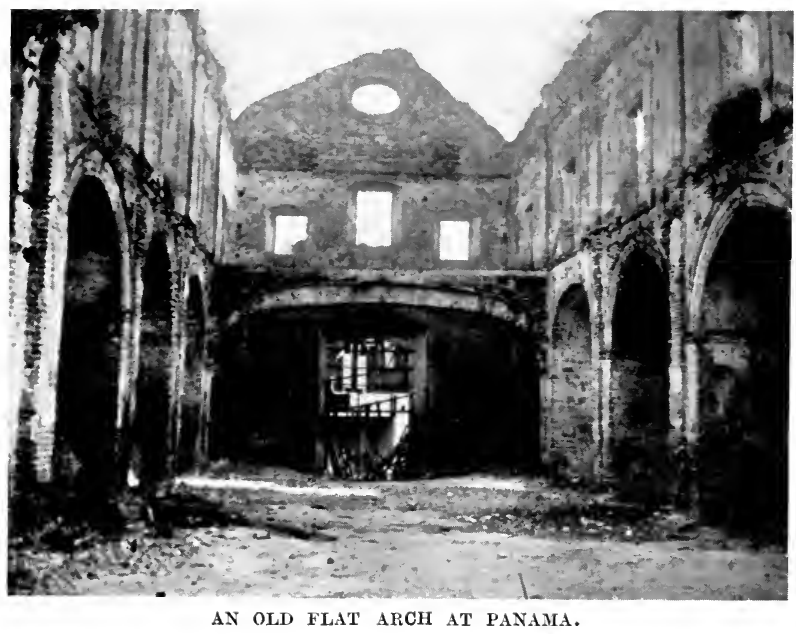

[To face page I74. 
$\therefore$ 
The combined cost of the Suez, Manchester, and Kiel Canals has been $\$ 205,000,000$.

The following important ship canals have been completed for smaller sums :-

U.S. S. St. Marie (somewhat more than) $\quad \ldots \quad \quad \ldots \quad \ldots \quad \$ 6,000,000$

Canadian ditto nearly $\quad \ldots \quad \ldots \quad 4,000,000$ Amsterdam $\quad \ldots \quad \ldots \quad \ldots \quad 10,000,000$

Corinth (about) $\quad \ldots \quad \ldots \quad \ldots \quad \ldots, 000,000$

Cronstadt (about) $\ldots \quad \ldots \quad \ldots \quad 10,000,000$

Welland (Lake Erie-Lake Ontario) $\quad \ldots \quad \ldots \quad \ldots \quad \ldots \quad 24,000,000$

Total $\quad \ldots \quad 59,000,000$

Adding these figures to those already given, we have a grand total of $\$ 264,000,000$ for the cost of nine of the greatest existing ship canals, which is about the same as the lowest current official estimate for the final cost of the Panama Canal.

In the case of a commercial company undertaking such a work as the Panama Canal, the charge for compounded interest increases as the unremunerative years 
advance at an appalling rate, which would surprise anyone not versed in the cumulative capability of figures which increase in "geometrical progression."

Fortunately it is not necessary for the United States to reckon the cost of the Canal in this way, and the Government have been in a peculiarly advantageous position for financing the Canal.

The bonds bear interest at 2 per cent., and in December, 1907, were slightly above 103. As all American banks have to deposit gold with the United States Treasury it evidently pays to take up and deposit these bonds, which reckon as gold, receiving 2 per cent. interest.

Moreover, the small amount of securities with Government guarantee in America renders such issues convenient, so that the Government can raise money more cheaply than with us, although for industrial purposes the rates may be higher.

At the present time the payments of Government pensions in connection with the Civil War are yearly diminishing at a 
rapid rate. Finally, there has been in the Treasury a large surplus of cash. Thus from one cause and another the expenditure already incurred has not yet been felt.

As I write the last lines of the account in which $I$ have endeavoured to state the salient facts relating to a great undertaking at only moderate length, I recall our departure from Colon harbour on the R.M.S. Orinoco homeward bound. I confess that after the Canal Zone most places seem only half alive, and I long to be back where one can watch human activities so great and so intelligent, while the spirit is soothed by the balmy air which blows warm and fragrant from the tropical forest.

May the arduous labours of the Isthmian Canal Commission be crowned with success! 
INDEX 


\section{INDEX}

A

Аввот, Brigadier-General Hy. L., 76

Alhajuela, 77

America, South, possibilities for white peasantry, 148-9

Anopheles mosquito, see also Malaria, 132, 137 Antwerp, port of, see Distances

Arango, Mr. R. M., 77

Aspinwall, W. H., and colleagues construct Panama Railway, 30

Asiatic ports, see Distances

Australia, see Distances

B

Barbadians as labourers, 104

Bohio, a bandoned site of dam, 70

C

California, rush of gold-seekers to, 29

Canal, Panama, national and commercial status defined, 39-43 
Canal, Panama, tide-level schemes, 52, 54-55

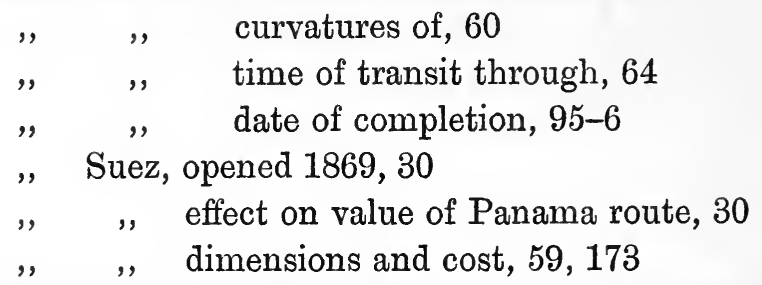

Caribbean Sea, Spain unable to protect her ships in, 27

Chagres, River, course of, 48

, , sudden rise of, 51

Charles V. of Spain, canal project, 26

Children, white, health of, on Isthmus, 143

Climate of the Isthmus, 140-2

Clubs for employees, 143

Colombia (formerly New Granada), treaty with

United States, 1846, 28

, Senate of, does not accept offer of

United States, 1903, 38

", want of sea-power, 39

Colon, protection from " northers," 78

„ yellow fever in, 129

Columbus discovers Bay of Limon, 25

Commission, Isthmian Canal, Report of 1901, 36-37

$$
\begin{aligned}
& \text {, " , } \quad \text { a second appointed, } \\
& 113 \\
& \text { " } \quad \text { " } \quad \text {, a third appointed, } 114
\end{aligned}
$$


Congress, Act of, sanctioning 85-foot-level canal, 1906, 53

Constantinople, conquest by Turks, 1453, 25

Contract Construction of Canal, proposed by Second

Commission, 114

Cortes searches for a strait, 26

Culebra, view of works from, described, 84-90

" Cut, form and dimensions of, 81-84

" , amount excavated in, 94

Currents in Canal advanced as objection to tidelevel scheme, 55

, $\quad$ tidal, below Milaflores, 66

$\mathrm{D}$

Dam, Bohio, abandoned, 70

", Gamboa, controlling feature of tide-level scheme, 54,57

, Gatun, as proposed in minority report of Board of Consulting Engineers, $56-58$

," $\quad$, plans of, April, 1908, 70-74

, Milaflores, 69

,, Pedro Miguel, 69

De Lesseps, Ferdinand, forms First Panama Canal Company, 1879, 31

, $\quad, \quad$ plan for tide-level canal, 52

Depew, Senator, on the cost of operating American ships, 168 
Dimensions of Panama and other Canals, 59-61 Distances, Shortening of, by Suez Canal, 160

\begin{tabular}{|c|c|c|}
\hline & " & ,, by Panama Canal,153-165 \\
\hline & ", & $\begin{array}{c}\text {, to Pacific Coast of North } \\
\text { America, 155, } 156\end{array}$ \\
\hline ', & $"$ & $\begin{array}{l}\text { " to Pacific Coast of South } \\
\text { America, 155, } 156\end{array}$ \\
\hline & " & $\begin{array}{l}\text { " to Asiatic ports, } 158,159 \text {, } \\
161,162\end{array}$ \\
\hline & $"$ & $\begin{array}{l}\text { Australian and New Zea- } \\
\text { land ports, 158, 161, } 162\end{array}$ \\
\hline
\end{tabular}

E

Employees, number of, on Canal Zone; 112

Engineers, French, ability of, 32

", Board of Consulting, Majority Scheme for tide-level canal, 53-55

, , , , , Minority Scheme for high-level canal, $56-70$

" names of chief, 113-115

" Corps of, U.S.A., and public works, 115

Excavation, amount of, by French Companies, 94

", by American Commission, 94 


\section{F}

Fever, Yellow, 121-132

, " geographical distribution of, 130-131

" Malarial, see Malaria

Floods of the Chagres River, 51

, control of, 54

Forests, tropical, insulate the Canal Zone, 39

Fortifications for defence of the Canal, 40, 78

French Companies, excavation accomplished by, 94

, Engineers, ability of, 32

, Investors, 31-32

\section{G}

Gallinger, Senator, on the lack of U.S. steamships trading with foreign ports, 167-8

Gamboa, site of controlling dam of the tide-level scheme, 54

Gatun dam, see Dam

, Lake, 56, 69

, locks, see Locks

Germany, steamships of, cost of operating as compared with American steamships, 169

Goethals, Colonel George W., Corps of Engineers, 20

" " , , , appointed Chairman of Commission and Chief Engineer, April, 1907, 115 
" Gold Roll," see Labour, skilled

", " Europeans on, 110

Golden Hill, highest original level at, 82

Gorgas, Colonel W. C., M.D., head of Department of Sanitation, 113, $125,126,130$

" $, \quad, \quad, \quad$ on the future of the white race in the tropics, $144-5$

Gorgona, workshops at, 97

Grant, President, recommends construction of Isthmian Canal, 1869, 34

Greeks as labourers, 107 Gulf ports, see Distances

$\mathrm{H}$

Hamburg, see Distances

Harbours, at terminals of Canal, 78

Havana, yellow fever at, 123

Hotels, Commission's, for employees, 111

I

Indies, East, original objective of Canal project, 26

Ismailia, effect of malaria at, 14

Italians as labourers, 107, 108

" as peasantry in the tropics, 149 


\section{$J$}

Jamaica, effect of Canal on position of, 164 Jamaicans as labourers, 104

, as policemen, 105

Japan, steamships of, to use Canal, 169

"see Distances

\section{$\mathrm{K}$}

Kiel Canal, dimensions of, 59-61

$$
\text { ", , cost, } 173
$$

Kingston, see Jamaica

\section{L}

La Boca, tide at, 65

" , scheme for locks abandoned, 67

Labour on the Isthmus, Chinese proposed, 106

$\begin{array}{llll}" & , & , & \text { West Indian, 101-106 } \\ " & , & , & \text { European, 106-110 } \\ " & \text { " } & \text { " } & \text { skilled, 110-112 } \\ " & \text { white, in tropical countries, 140-150 } \\ \text { " } & \text { Panamanian, 134 }\end{array}$

Limon, Bay of, discovered by Columbus, 25

Liverpool, see Distances

Lock at Pedro Miguel, depth of water above, 68

,, gates described, 63

Locks," dimensions of proposed, 60, 62

, at Gatun, distance from deep water, 62 
Locks at Gatun, course of Canal below, 62

" , depth of water above, 68

,, at Milaflores, variable lift of, 65

Longitude, meridians between which distances vid Suez and Panama are equal, 162

$\mathrm{M}$ -

McKinley, President, 35

Magellan, Straits of, discovered 1520, 26

Malaria, 132-137, 146

Manchester Ship Canal, cost of, 173

Manila, distance from New York viá Suez and vid

Panama, 159

Marines, U.S., force of on Isthmus, 118

Mauretania, s.s., dimensions of, 59, 60

Meteorology of Isthmus, 76

Mexico, war of United States with, 28

Milaflores, see Dams and Locks

Mississippi, basin of, 164

$\mathrm{N}$

Naos, Isle of, 67, 92

New Granada, treaty of U.S. with, 28

New York, see Distances

New Zealand, see Distances

Nicaragua, canal route through, 28,37 


\section{0}

Obispo, change in course of Chagres River at, 48 Oregon, battleship, voyage of, 1898, 34 Organisation, efficiency of, in 1907 and 1908 compared, 86-88

\section{$\mathrm{P}$}

Panama Canal Company, First, formed 1879, 31

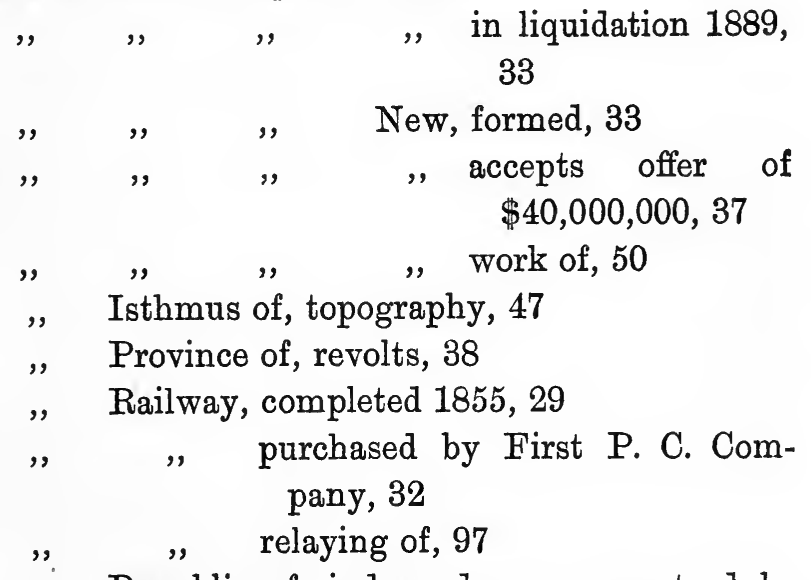

" Republic of, independence guaranteed by U.S., 38, 39

Pedro Miguel, see Dams and Locks

Peru, Spanish possessions in, protected by Isthmus, 27

Police, force of, 117

Pneumonia among negroes in the tropics, 139

Plague, bubonic, 139 
$\mathrm{R}$

Rainfall on the Isthmus, 51

Reed discovers cause of yellow fever, 124

Rio Grande, valley of, 49

Ross, Ronald, discovers cause of malaria, 123

Roosevelt, President, 53, 96

Root, the Hon. Elihu, 168

$\mathrm{S}$

St. Lawrence, the, a supposed route to China, 26 San Blas route, 36

Sanitation, Department of, 118, 125, 128, 133, 139 Sea-power, importance of, in Isthmian affairs, 39

Societies, benevolent, in the Canal Zone, 144

Spaniards as navvies and as peasantry in tropics, 108-110, 149

Spanish War, voyage of Oregon during, 34 Steam shovel, rate of loading by, 91

Steamships available for Canal transit, 165-169

, relative cost of operating American and European, 169

Stegomyia mosquito, mode of infection by, 124 Stephens, John F., chief engineer 1905-1907, 113-114

$\mathrm{T}$

Tide, range of, at La Boca, 65

Tolls on the Panama Canal equal for all nations, 43 
Tourists, attractions for, on the Isthmus, 89

Track-shifter, the, 91

Transportation of spoil in Culebra Cut, 91-93

Treaty between U.S. and New Granada, 1846, 28, 38

\begin{tabular}{|c|c|c|c|}
\hline ", & ", & , & $\begin{array}{l}\text { Great Britain (Clayton- } \\
\text { Bulwer).1850, } 29\end{array}$ \\
\hline ", & ", & ", & Great Britain (Hay- \\
\hline & & & $\begin{array}{l}\text { Pauncefote) 1901, 19, } \\
37,40\end{array}$ \\
\hline ", & ", & ", & $\begin{array}{l}\text { Republic of Panama, 1903, } \\
39,40,42\end{array}$ \\
\hline
\end{tabular}

Tropics, future of white race in, 140-150

$\mathrm{U}$

United States, civil war in, interrupts Canal scheme, 30

Unloader, the, for dirt-cars, 91

\section{W}

Wages on the Isthmus, see Labour

Wallace, John F., chief engineer, 1904-1905, 113

Water supply for high-level canal, 74-77

West Indians, relations with American employers,

102-104

, " $\quad$, $\quad$ immunity from yellow fever, 122
$\quad$ see also Labour 
White race, future of, in tropics, $140-150$

Women, white, life of, on Isthmus, 142

\section{Y}

Y.M.C.A. and management of clubs, 144

\section{z}

Zone, the Canal, 19 


\section{DAY USE}

\section{RETURN TO DESK FROM WHICH BORROWED}

\section{LOAN DEPT.}

This book is due on the last date stamped below, or on the date to which renewed.

Renewed books are subject to immediate recall.

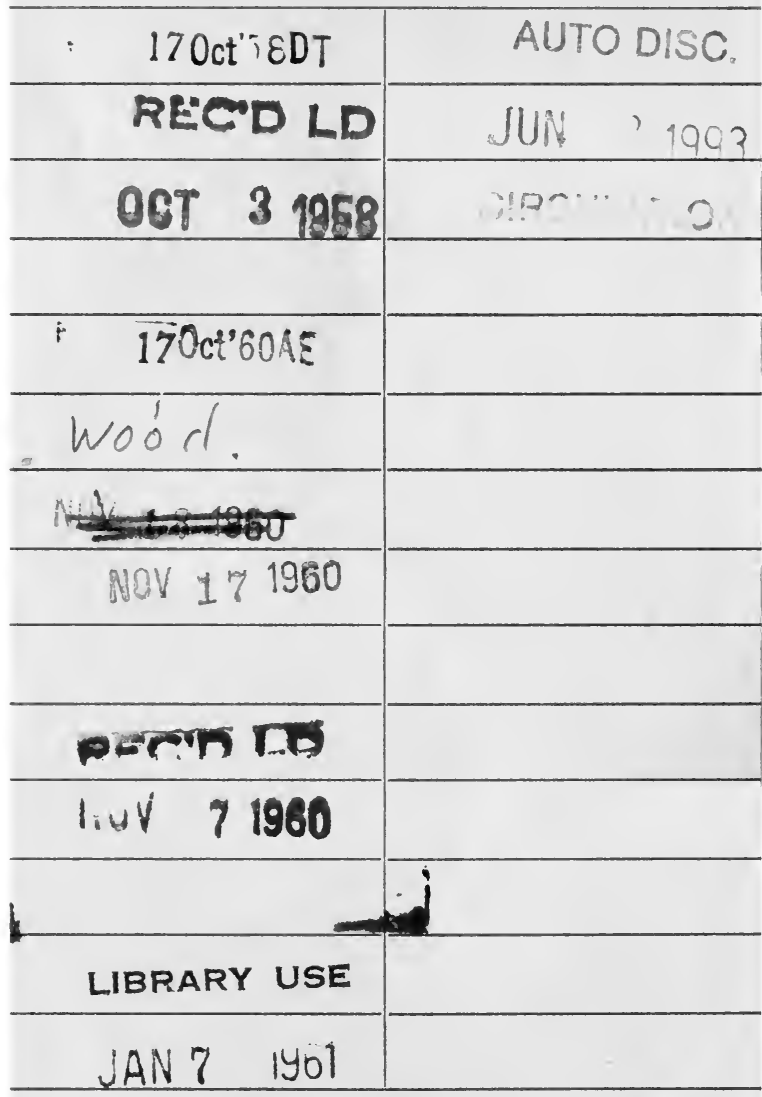

LD $21 \mathrm{~A}-50 m-9,{ }^{\prime} 58$

$(6889 \mathrm{~s} 10) 476 \mathrm{~B}$
General Library

University of California Berkeley 


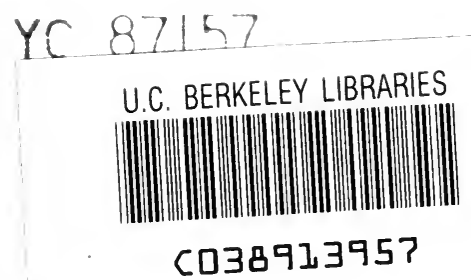

C03891 3957

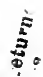

\section{1}

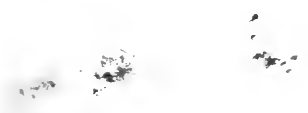

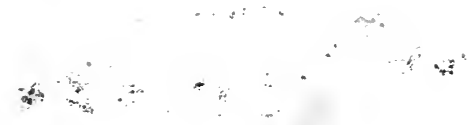


ax... 